\title{
Kupní smlouvy k lenním statkům frýdlantského knížectví (vévodství)
}

\author{
Marek Starý
}

\author{
Právnická fakulta, Univerzita Karlova
}

Kontaktni e-mail: starym@prf.cuni.cz

\section{Purchase Contracts for the Fief Estates of the Friedland Principality (Duchy)}

\begin{abstract}
:
The Duchy of Friedland, this "state within a state", as characterized by many authors, existed only for a very short period of time. The fief estates, which were acquired by the imperial military leader Albrecht von Wallenstein (Valdštejn) in the sale following the Battle of White Mountain, were first declared a principality in 1624 and then a duchy in 1627. Immediately after Wallenstein's assassination in 1634, this remarkable constitutional unit was immediately liquidated.

Wallenstein kept most of the acquired estates under his direct control, and they thus became chamber ducal estates (this was especially true for all larger, economically strong towns). He left only a relatively small part of his property to the institutions of the Catholic Church - logically, although he provided them with political and property support, in the latter respect he certainly did not dazzle with excessive generosity. On the other hand, he left large estates to various persons (his relatives, subordinate officers, officials, in some cases the original pre-White Mountain owners, etc.), who took them over from him as a Friedland fief (de iure actually sub-fief, as Wallenstein himself was a vassal of the emperor who was the Czech king).

Some of these people received the property as a gift ("Donatio") as a sign of Wallenstein's generosity. In most cases, however, it was a standard property transaction, where the acquirers paid a more or less adequate amount of money for the fief estate, or their receivables from the Friedland landowner were offset. The legal title of the transfer of possession thus became the standard purchase ("Erblehenkauf"), recorded in a contract approved, sealed and signed by both parties. Copies of these contracts are concentrated in the manuscript sign. B 16, stored in the National Archives in Prague, other originals and copies of individual documents of this type can be recorded in other archives. This study is devoted to their content analysis.

Purchase contracts for Friedland fief estates represent a set of documents, the significance of which can be seen on at least four levels. From the most general point of view, they contribute to the knowledge of early modern legal culture and legal language (although German, not Czech). Secondly, they are evidence of the administrative practice of the
\end{abstract}


court office of the Duchy of Friedland, which prepared these documents. They are also a contribution to the history of fief law in the Czech lands. Finally, they provide a number of specific information about individual fief estates, and thus also about the regional history of northeastern Bohemia, where Wallenstein's "terra felix" was located. The surviving contracts relate to more than forty larger and smaller estates, which fell into the hands of the vassals in the short days of Wallenstein's rule over this region.

The court office of the Duchy of Friedland, on whose premises the contracts were created, was a relatively advanced bureaucratic body with several lawyers - the former prosecutor Jan Jezber of Kolivá Hora had probably the greatest reputation, who himself bought the Choteč fief estate in 1624. Štěpán Ilgen from Ilgenau, a native of Leipzig, reached the significant position of Friedland Chancellor. Many office councilors were also graduates of law education. However, it is very interesting that the set of surviving contracts is largely characterized by its variability. Although a more or less uniform structure was followed (dating, definition of the contracting parties, and the subject of the contract, determination of the price and the method of payment, set of rights reserved to the landlord, confirmation of will and corroboration), contracts offer various and in some cases significantly different specific solutions. On the other hand, different wording did not always mean a difference in content. For example, the extent of the landlord reservations, which Wallenstein reserved in the treaties as chief lord of the Duchy of Friedland and among which brewing played the most important role, apparently had a standard scope, regardless of the specific diction.

Purchase contracts related to Friedland fief estates represent only one type of documents framing the development of this extremely interesting state law unit. The study of others and, in the future, comprehensive elaboration of the history of the Friedland estate, or of the entire duchy, remain urgent challenges for further legal historical research.

\section{Keywords:}

Duchy of Friedland; purchase contract; fief; regal law; Thirty Years' War; Wallenstein

\section{Klíčová slova:}

Frýdlantské vévodství; kupní smlouva; léno; regál; třicetiletá válka; Valdštejn

DOI: $10.14712 / 2464689 X .2020 .30$

Frýdlantské vévodství, vybudované ve dvacátých letech 17. století a zaniklé již krátce před dovršením prvního desetiletí své existence, představuje mimořádně zajímavý fenomén z pohledu právní i správní historie. Na atraktivitě mu jistě přidává úzké propojení s osobou císařského generalissima Albrechta z Valdštejna, u něhož nelze oddiskutovat (bez ohledu na velmi rozporuplné hodnocení ze strany jednotlivých historiků), že patří k nejvýznamnějším Čechům evropských dějin. Sama Valdštejnova osobnost a jeho životní osudy tak patří k velmi oblíbeným a nesčetněkrát pod různou optikou prozkoumaným tématům evropské historiografie (dominantně pochopitelně české a německé). ${ }^{1} \mathrm{~V}$ nedávno

1 Obsáhlá Valdštejnská bibliografie vyšla již ve druhé polovině 19. století na stránkách časopisu Mittheilungen des Vereines für Geschichte der Deutschen in Böhmen (= MVGDB), viz SCHMID, G. Die Wallenstein-Literatur (1626-1878). Bibliographische Studie. $M V G D B, 1879,1 / \mathrm{XVII}$, Beilage, s. 65-143; TÝŽ. Die Wallenstein Literatur. Erste Ergänzung (1619-1681). Bibliographische Studie. MVGDB, 1882, 2/XXI, 
vydaných Dějinách Jičína tak autor konstatoval, že ,v současné době je všestranné poznávání Valdštejnova života v podstatě ukončeno“.2 At' už ale toto tvrzení je či není př́liš optimistické, jedno je jisté - o Frýdlantském vévodství totéž rozhodně prohlásit nelze.

Paradoxně totiž platí, že dodnes neexistuje jediná vědecká monografie, která by se pokusila krátké dějiny tohoto státoprávního celku všestranně zmapovat, či dokonce zhodnotit. Př́slušné pasáže v jednotlivých Valdštejnových biografí́ch jsou poměrně kusé a roztř́ššěné a zachycují jen hlavní údaje, zaměřené především na samotné budování vévodství, jeho vnitřní organizaci a správu. ${ }^{3}$ Pokud jde o Valdštejna jako zeměpána, dodnes zůstává prakticky nepřekonána velmi stará (1834) práce Friedricha Förstera, ${ }^{4}$ samostatné obsáhlé práce byly věnovány Valdštejnově vládě v Meklenbursku ${ }^{5}$ a v Zaháňsku. ${ }^{6}$ Český historik, který se chce seznámit s Valdštejnovým bojem o dědictví Smiřických, jeho aktivitami v rámci redistribuce konfiskovaného majetku, vytvořením Frýdlantského knížectví a později vévodství, osudy jednotlivých komorních a lenních statků a likvidací Frýdlantska po Valdštejnově zavraždění, pak musí dodnes sáhnout po příslušných pasážích monumentálních Dějin konfiskací z pera Tomáše Václava Bílka. ${ }^{7}$ Ten pak materii doplnil a rozvedl v méně známé, samostatné a dodnes v podstatě nepřekonané německy psané monografii. ${ }^{8}$ Vynikající práci zaměřenou na frýdlantské hospodářství, programově napojené na Valdštejnovy válečné aktivity, publikoval v roce 1929 právník a historik Anton Ernstberger. Žel, organizačně-správních otázek se v ní výrazněji nedotkl. ${ }^{9}$

Beilage, s. 1-48; TÝŽ. Die Wallenstein Literatur. Zweite Ergänzung (1620-1884). Bibliographische Studie. $M V G D B, 1885,2 / X X I I I$, Beilage, s. 1-39; LOEWE, V. Die Wallenstein-Literatur. Dritte Ergänzung (1628-1895). Bibliographische Studie. $M V G D B$, 1895/1896, 3/XXXIV, s. 277-315; TÝŽ. Die Wallenstein-Literatur. Vierte Ergänzung. Bibliographische Studie. $M V G D B, 1902$, 4/XL, s. 514-534. Starší prameny a literaturu sebral též ZÍBRT, Č. Bibliografie české historie. Díl V. Praha: Česká akademie císaře Františka Josefa pro vědy, slovesnost a umění, 1912, s. 38-126 (č. 12464-14209).

2 FRANCEK, J. Dějiny Jičína. Praha: Rybka Publishers, 2010, s. 116.

3 Srovnej např. JANÁČEK, J. Valdštejn a jeho doba. Praha: Svoboda, 1978, s. 284-289, 346-356; POLIŠENSKÝ, J. - KOLLMANN, J. Valdštejn. Ani císař, ani král. Praha: Academia, 2001, zejm. s. 75-80; FRANCEK, J. Navzdory závisti. Životní přiběh Albrechta z Valdštejna. Praha: Havran, 2007, s. 59-62.

4 FÖRSTER, F. Ch. Wallenstein, Herzog zu Mecklenburg, Friedland und Sagan, als Feldherr und Landesfürst in seinem öffentlichen und Privat-Leben. Eine Biographie. Potsdam: Riegel, 1834, passim; TÝŽ. Wallenstein als regierender Herzog und Landesherr. In: Historisches Taschenbuch. V. Jahrgang, Leipzig: Brockhaus, 1834, s. 1-123. Tato publikace je ovšem prakticky pouze samostatným, doslovně totožným vydáním části publikace první.

5 Zde je třeba zmínit v prvé řadě záslužné a dodnes cenné studie k Valdštejnově vládě v Meklenbursku, jež publikoval na stránkách periodické řady Jahrbücher des Vereins für meklenburgische Geschichte und Alterthumskunde (=JVMGA) její uspořadatel, meklenburský velkovévodský tajný archivní rada Dr. Lisch - srovnej především LISCH, G. Ch. F. Wallensteins Abzug aus Meklenburg im Jahre 1629. JVMGA, 1870, XXXV, s. 45-79; TÝŽ. Ueber Wallensteins Regierungsform in Meklenburg. JVMGA, 1871, XXXVI, s. 3-48. Dále viz HUNZIKER, O. Wallenstein als Landesherr insbesondere als Herzog von Meklenburg. Zürrich: Schmidt, 1875, passim; GROTEFEND, O. Meklenburg unter Wallenstein und die Wiedereroberung des Landes durch die Herzöge. JVMGA, 1901, LXVI, s. 227-284.

6 HEINRICH, A. Wallenstein als Herzog von Sagan. Breslau: Goerlich \& Coch, 1896, passim.

7 BÍLEK, T. V. Dějiny konfiskací v Čechách po r. 1618. Praha: Museum království českého, 1882-1883, zejm. s. 732-832.

8 BÍLEK, T. V. Beiträge zur Geschichte Waldstein 's. Prag: Franz Riwnác, 1886, passim.

9 ERNSTBERGER, A. Wallenstein als Volkswirt im Herzogtum Friedland. Prager Studien aus dem Gebiete der Geschichtswissenschaft. 19. Heft. Reichenberg in Böhmen: Sudetendeutscher Verlag Franz Kraus, 1929, passim. 
Naopak, výrazně správně-historické zaměření vykazuje obsáhlá studie (bohužel poněkud „ukrytá“ v moravském regionálním periodiku Studie Muzea Kroměřížska), již vydal v roce 1983 Josef Svátek. ${ }^{10}$ Tu lze vedle Bílkových prací zřejmě považovat za druhý vrchol, pokud jde o dosažení poznání dějin Frýdlantského vévodství. Citovaná Svátkova práce je zaměřena především na činnost frýdlantské dvorské kanceláře jakožto klíčového orgánu politické správy vévodství, dotýká se ale též významným způsobem činností dalších ústředních orgánů Frýdlantska, především pak dvorské komory. Kromě klasického správně-historického pohledu aplikoval autor i př́stup pomocně vědný - ostatně je zjevné, že k tématu se dostal prostřednictvím své dřívější, speciálněji zaměřené studie věnované erbovním privilegiím, která z frýdlantské dvorské kanceláře vycházela. ${ }^{11}$

V nejnovější době byly publikovány drobnější práce snažící se postihnout právněhistorické12 či ekonomické13 aspekty fungování Frýdlantského vévodství, popř́padě se pokoušející o jisté zobecnění charakteristických rysů Valdštejnovy vlády v jednotlivých jeho zemích. ${ }^{14}$ Dluh české historiografie vůči Frýdlantsku tím byl možná lehce snížen, v žádném případě ale nelze ani na okamžik uvažovat o jeho smazání či alespoň podstatné redukci. Dosavadní neutěšená bilance zájmu o dějiny Valdštejnova rodového vévodství je přitom dvojnásob zarážející z toho pohledu, že se k nim zachovalo značné bohatství archivních materiálů, umožňujících jejich detailní zmapování. Trojnásob pak s ohledem na absolutní jedinečnost jeho státoprávního postavení. Valdštejnova „terra felix“ totiž představuje zcela unikátní zásah do vnitřní integrity Českého království, v jehož hranicích se na pozadí pobělohorských konfiskací zrodila. Velmi dobře to vystihl historik Zdeněk Kalista, který Frýdlantsko definoval jako ,jakýsi stát ve státě, polosuverénní útvar, vymykající se z rámce království a vázaný k němu jen úvazky lenními“. ${ }^{15} \mathrm{Ke}$ zmíněné větě se ještě sluší doplnit, že postavení Valdštejnovy domény, jejímž centrem byl navzdory názvu Jičín, nebylo navíc dobovými právními akty řešeno zcela jednoznačně.

Pozadím a zároveň jakýmsi pomyslným podhoubím pro vytvoření frýdlantského vévodství se, jak známo, staly obrovské majetkové přesuny, k nimž došlo z rozhodnutí vítězného Ferdinanda II. po vcelku tristní porážce českého stavovského povstání v bitvě na Bílé hoře. Právě v tomto zlomovém období se naplno ukázala velikost císařského plukovníka, který se neváhal vzepřít svému předurčení a v příznivých podmínkách se upnul k cílům, v předbělohorské době naprosto nedosažitelným. Ne vždy byly volené prostředky morální,

10 SVÁTEK, J. Dvorská kancelář Valdštejnova frýdlantského vévodství. Studie Muzea Kroměřřžska, 1983, S. 43-96.

11 SVÁTEK, J. Erby z dvorské kanceláře frýdlantského vévodství. Heraldická ročenka, 1977, s. 69-76.

12 STARÝ, M. Absolutismus „na zelené louce“ (K postavení zeměpána ve Frýdlantském vévodství). In: SCHELLE, K. - VOJÁČEK, L. (eds.). Stát a právo v období absolutismu. Acta Universitatis Masarykianae Brunensis, Iuridica. Brno: Masarykova univerzita, 2005, No. 295, s. 249-258; TÝŽ. Frýdlantské vévodství a jeho státoprávní postavení v rámci České koruny. In: MALÝ, K. - SOUKUP, L. (ed.). Vývoj české ústavnosti v letech 1618-1918. Praha: Karolinum, 2006, s. 135-157.

13 KOVÁŘ, M. Albrecht z Valdštejna - hospodář a podnikatel. Historický obzor, 1994, 9/V, s. 194-199.

14 STARÝ, M. Political and Administrative System of Waldstein's Lands. Krakowskie Studia z Historii Państwa i Prawa. Cracow Studies of Legal and Constitutional History, 2012, 1/V, s. 61-69.

15 KALISTA, Z. Valdštejn. Historie odcizeni a snu. Praha: Vyšehrad, 2002, s. 106. 
ne vždy byly právně bezvadné. Jisté ale je, že šanci, kterou císařský dvůr po bělohorském vítězství svým věrným nabídl, dokázal Valdštejn využít jednoznačně nejlépe. ${ }^{16}$

Na počátku byl frýdlantskému panství a dalším k němu připojeným statkům propůjčen status rodového svěřenectví (fideikomisu), a to císařským majestátem z 12. srpna 1622. ${ }^{17}$ O měsíc později, 15. zárí, dal Ferdinand II. Albrechtovi další listinou vedle jiných privilegií též povolení ke zř́zení majorátu. ${ }^{18}$ Velmi specifická přitom byla skutečnost, že Frýdlant nebyl statkem zpupným, nýbrž lenním. ${ }^{19}$ Také další alodní panství, jež Valdštejn postupně skoupil, byla v několika vlnách vyňata $\mathrm{z}$ režimu zemských desk a přeměněna $\mathrm{v}$ léna. V první fázi to bylo 49 statků, které císař Albrechtovi udělil listinou z 30. záŕí 1623, ${ }^{20}$ téhož dne za ně složil Albrechtovým jménem lenní slib jeho př́ibuzný Maxmilián z Valdštejna. ${ }^{21}$ Další analogické transformace právního titulu držby se pak uskutečnily v letech 1624, $1627,1628,1629$ a 1633.22

16 K postupnému skupování statků nejpodrobněji (ovšem nikoli s důrazem na chronologické hledisko) BÍLEK, Dějiny konfiskaci v Čechách po r. 1618, s. 764-830; TÝŽ. Beiträge zur Geschichte Waldstein's, s. $39-130$.

17 Státní oblastní archiv (= SOA) Praha, fond Rodinný archiv Valdštejnů (= RAV), Listiny, sign. N-4, i.č. 17. Edice FÖRSTER, F. Ch. Wallenstein's Prozeß vor den Schranken des Weltgerichts und des K. K. Fiscus zu Prag. Leipzig: B.G. Teubner, 1844, Urkundenbuch, s. 3-5, No. 1.

18 RAV, Listiny, sign. N-6, i.č. 19. V pozdějším rakouském právu byl majorát typem fideikomisu, specifickým zvláštní posloupností dědiců, pro niž byla charakteristická jakási kombinace zásad primogenitury a seniorátu. To jest, majorátní panství dědil nejstarší z nejbližších mužských příbuzných posledního držitele. Srovnej § 619 Všeobecného rakouského zákoníku občanského ABGB (č. 946/1811 Sb. z. s.) a výklad, který podal KRČMÁR̆, J. Fideikomisy. In: HÁCHA, E. - HOBZA, A. - WEYR, F. - HOETZEL, J. - LAŠTOVKA, K. (usp.). Slovník veřejného práva československého. Svazek I. Brno: Polygrafia, 1929, s. 596-597. V právu habsburských zemí 17. století byl ale pojem majorát užíván ve smyslu španělského vzorového institutu, pro nějž byl naopak charakteristický důsledný přechod v primogeniturní linii. Fideikomis byl pak obecný pojem reprezentující rodové svěřenectví. Rozdíl mezi fideikomisem v podobě známé z poklasického ř́mského práva a původem španělským majorátem tkvěl ve způsobu dědického nástupnictví a jeho kvalitě. Blíže URFUS, V. Rodinný fideikomis v Čechách. Sborník historický, 1962, IX, s. 199-211. Z další literatury věnované fideikomisům viz KAPRAS, J. Velkostatky a fideikomisy v českém státě. Studie historická. Právnické rozhledy, 1918-1919, XIX, č. 2, s. 32-34, č. 3, s. 48-53, č. 4, s. 65-72, č. 6, s. 118-122, č. 7-10, s. 119-122; PINSKER, Č. České zř́zeni rodové. Kapitola z práva svěrenského. Praha: Edvard Leschingr, 1907; ŠOLLE, V. Fideikomisy a jejich současná archivní problematika. Archivní časopis, 1971, 2/XXI, s. 103-115; a naposledy KOBER, J. Fideikomis (svěřenství). In: SCHELLE, K. - TAUCHEN, J. (eds.). Encyklopedie českých právních dějin. II. svazek. Plzeň: Aleš Čeněk, 2016, s. 492-504.

19 Samotný text listiny o povolení fideikomisu uvádí, že lenní list na frýdlantské panství byl vydán 5. června 1622. Lenní přísahu složil Albrecht císaři již o den dříve, 4. června. Národní archiv (=NA) Praha, fond Česká dvorská kancelář (= ČDK), sign. II A 4, kart. 131, i.č. 577.

20 RAV, Listiny, sign. N-10, i.č. 24.

21 C̆DK, sign. II A 4, kart. 131, i.č. 577.

22 Dochovány jsou ještě další dva lenní listy z 5. března 1624 a 4. května 1627. RAV, Listiny, sign. N-11, i.č. 25, sign. N-19, i.č. 34. Další rozšiřování lenních statků dosvědčují relace o jejich propuštění ze zemských desk, intabulované do NA Praha, fond Desky zemské, Desky zemské větší (= DZV) 294, fol. F 28v - F 29r (14. ledna 1628) a K 17r - K 17v (9. května 1628); DZV 295, fol. M 25v - M 26r (29. ledna 1629); DZV 296, fol. A 26v - A 27r (16. května 1629); DZV 298, fol. L 17r - L 18r (27. dubna 1633). Zároveň s posledním propuštěním byla do desk zemských vložena plná moc, kterou vévoda udělil svému bratranci a švagrovi v jedné osobě, Maxmiliánovi z Valdštejna, a v jeho nepřítomnosti hraběti Adamovi Erdmanovi Trčkovi, Ladislavovi Burianovi z Valdštejna a frýdlantskému zemskému hejtmanovi Dětřichu Malovcovi, a v níž je mimo jiné oprávnil „statky J[eho] M[ilos]ti dědičné z týchž desk ... vymazati dáti“. DZV 298, fol. L $18 \mathrm{r}-\mathrm{L} 19 \mathrm{r}$. 
To, že Valdštejn přijímal nakoupená zboží jako léno, bylo poměrně neobvyklé, nebot' na lenní držbu bylo v Čechách obecně nahlíženo jako na kvalitativně horší právní panství, než jaké reprezentovalo vlastnictví svobodné (zpupné). Dokladem toho je i skutečnost, že se nucená přeměna alodů v léna objevila jako forma trestu již po rozložení stavovského odboje v roce 1547, a stejně tak i po Bílé hoře. A nic na tom nemění skutečnost, že šlo rozhodně o jeden z mírnějších trestů, dopadajících na ty, jejichž skutečné či domnělé provinění vưči královskému majestátu mělo méně závažný charakter. Valdštejn ale sám o převedení skoupených konfiskátů, resp. dalších zboží na královská léna usiloval, ba sám to císaři nabídl. Je to doloženo např. již v březnu 1623 při jednáních o odkoupení statků ponechaných slabomyslnému Jindřichovi Jiřímu Smiřickému, kdy Albrecht avizoval, že „,všecky mý statky J[eho] M[ilosti] c[ísařské] pod léno dáti chci““. ${ }^{23}$ Najít důvod není složité. Jak velmi trefně konstatoval Zdeněk Kalista, již velmi záhy se jedním z Valdštejnových cílů stalo ohromující komplex získaných statků „,co možná vymanit z dosahu jiných činitelů, než je on sám“ “. ${ }^{24} \mathrm{~K}$ tomu bylo ovšem třeba najít způsob, jak je právně odlišit od jiných velkých šlechtických dominií, která se v Čechách vytvářela. A v tomto směru nabízel lenní institut značnou perspektivu.

Sám o sobě ale lenní status ještě Valdštejnovým statkům žádné zvláštní výjimečnosti nedodával. Tu jim propůjčila jednak jeho kombinace s rodovým svěřenectvím, jednak - a to především - císařské privilegium, jímž bylo Valdštejnovi z moci českého krále 13. května 1623 uděleno zcela výjimečné právo zř́ídit na frýdlantském dominiu a dalších k němu připojených lenních državách vlastní právní řád. Stalo se tak na jeho prosbu a s odkazem na podobné výsady, jimž se těšili obyvatelé vedlejších zemí České koruny a které prý obdrželi od Ferdinandových předchůdců („die jenigen Kaiser: und Königlichen Concessionen, welche andere Unsere Underthanen und Lehenleute in Schlesien, und beiden Marggrafthumbern Ober: und Nieder Laussitz jetzterwehnten Rechtens halber, von Unsern hochgeehrten Vorfahren erlanget, und in übung gebracht" $).{ }^{25}$ Skutečnost, že toto privilegium bylo vydáno již několik měsíců před shora zmíněným odevzdáním 49 statků pod lenní svrchovanost císaře, přitom jen znovu dotvrzuje, že převedení získaných statků na královská léna představovalo od samého začátku jeden z významných momentů Valdštejnových ambiciózních plánů. ${ }^{26}$

Jejich dílčím vyvrcholením se ale stal až další diplom, vydaný ve Vídni 12. března 1624 ve formě pergamenové knihy svázané v červeném sametu a opatřené přivěšenou císařskou zlatou bulou. V něm Ferdinand II. na výslovnou Albrechtovu žádost povýšil jeho české statky, vyjmenované v prozatím vydaných lenních listech, na knížectví („erhöhen und bestettigen mehrgedachte Herrschafft Friedtlandt sambt denen andern, in Unserm Erbkönigreich Beheimb gelegenen und in underschiedlichen zweien darüber auff gerichten Lehenbrieffen deren der aine den neündten Monatstag Septembris im ein Tausendt, sechs Hundert und drei und zweintzigsten, der ander aber den fünfften Martij dess ein Tausendt,

23 BÍLEK, Beiträge zur Geschichte Wallensteins, s. 260-261, př́loha č. XXIV.

24 KALISTA, Valdštejn, s. 191.

25 RAV, Listiny, sign. N-7, i.č. 21.

26 Za pozornost stojí také skutečnost, že Valdštejn nepodřídil panovníkovi jako léna všechny statky, které v té době držel, ale zjevně pouze ty, s nimiž jako se součástí svého dominia počítal. Tak se ve výčtu udělených panství neobjevují zejména ta, která později směnil s Magdalenou Trčkovou z Lobkovic. 
sechs Hundert und vier und zwaintzigisten Jahrs, in Unser Statt Wien datirt seind, specificirten darzue geschlagenen Herrschafften, Schlössern, Gründt und Güettern mit denen biss anhero gehabten Regalien, Herrligkeitten, Obrigkheitten undt Pertinentien zu ainem sonderbahren Fürstenthumb“), které mělo navždy zůstávat knížecím lénem („fürstlichs Lehen“). ${ }^{27} \mathrm{~V}$ tomto okamžiku byla již vnější odlišnost Valdštejnovy domény naprosto zjevná a prakticky bezpř́ikladná. Krumlovské vévodství pro Jana Oldřicha z Eggenberka bylo zř́zeno až později, navíc šlo pouze o titulární, nikoliv reálně státoprávní útvar, další český pobělohorský kníže Zdeněk Vojtěch Popel z Lobkovic byl knížetem bez knížectví. Vlastně jedinou analogii z českého (respektive moravského) prostředí tak představuje vytvoření opavského knížectví pro legitimizovanou nemanželskou linii Přemyslovců v roce $1318,{ }^{28}$ jehož srovnatelnost je ale už s ohledem na obrovský časový odstup velmi problematická.

Z hlediska právního hodnocení privilegia je nesmírně důležité, že je Ferdinand II. vydal z moci českého krále a bylo vystaveno českou dvorskou kanceláří. ${ }^{29}$ Už tím bylo jednoznačně dáno, že se nově vytvořené knížectví nevyčlenilo z Českého království, ale zůstalo jeho integrální součástí. Míra jeho samostatnosti nebyla v listině řešena do podrobností, svrchovanosti českého krále se - kromě opakovaných odkazů na lenní charakter knížectví - dotýkají jen dvě pasáže dispozice. V první si císař pro futuro vyhradil odvádění obecné berně, domovních a dalších daní, posudného a dalších dávek, které jsou v Čechách placeny („Belangendt aber die algemäinen Landescontributionen, Hauss- und anderer Steüern, Biergelder und Bewilligungen, wie die genennet werden möchten und wie dieselbten von alters hero in Unserm Königreich Behaimb geräicht und gegeben worden“), ve druhé pak paušálně a značně neurčitě zachoval sobě a svým nástupcům všechny královské regály, práva a spravedlnosti, at’ už spočívají v čemkoliv (,Massen Wir auch alle königliche Regalia, Recht und Gerechtigkeitten, wie die nahmen haben möchten, für Uns und Unsere Erben, nachkommende Könige zue Beheimb hiermitt krafftiglich reseruirt unnd vorbehalten haben wollen“). Ve skutečnosti ale klasická výhradní práva vykonával ve svém knížectví Valdštejn, který razil od roku 1626 vlastní mince ${ }^{30}$ a stejně tak se pokoušel i o těžbu drahých kovů, resp. jiných nerostů. ${ }^{31}$

27 RAV, Listiny, sign. N-12, i.č. 26; úřední opis privilegia je též v NA Praha, fond Salbuchy (= SAL), kniha č. 26 , i.č. 11 , fol. $242 \mathrm{v}-251 \mathrm{r}$.

28 Z hlediska právněhistorického dodnes nejpodrobněji zhodnotil dějiny Opavska ve středověku KAPRAS, J. O státoprávních poměrech Opavska. Věstnik Matice opavské, 1908, XVI, s. 35-49, 1909, XVII, s. 17-54; TÝŽ. Opavské právní dějiny doby knížecí. Věstník Matice opavské, 1918, XXIV, s. 3-45; k vzniku Opavska a jeho dělení v době vlády tamní linie Přemyslovců naposledy STARÝ, M. Ducatus, nebo Terra? (Na okraj 700. výročí vzniku Opavského vévodství). Právněhistorické studie, 2019, roč. 49, č. 1, s. 25-61. Je ovšem nepochybné, že právní dějiny tohoto knížectví by si zasloužily moderní syntetické zpracování.

29 Podepsáni jsou pod ní kromě panovníka nejvyšší kancléř, kníže Zdeněk Vojtěch Popel Lobkovic, vicekancléř Ota z Nostic a sekretář Jan Rašper z Kolče.

30 K Valdštejnovu mincovnictví především MEYER, A. Albrecht von Wallenstein (Waldstein) Herzog von Friedland und seine Münzen. Wien: Selbstverl., 1886; NOHEJLOVÁ, E. Mincovnictví Albrechta z Valdštejna. Numismatický časopis československý, 1934, X, s. 28-73. Ačkoliv s ražbou mincí začal Valdštejn prokazatelně již v roce 1626 , Ferdinand II. mu ji formálně povolil až 16. února 1628. Opis privilegia je v NA Praha, fond Valdštejniana (=VL), sign. F 67/28/2, kart. 43, fol. 72v - 80r.

31 Podrobněji k těžbě a zpracování kovů a nerostů ERNSTBERGER, Wallenstein als Volkswirt im Herzogtum Friedland, s. 61-75. 
Frýdlantsko se tak ocitlo v poněkud schizofrenní pozici, kdy na jedné straně zůstávalo součástí Českého království a tamní statky byly vystaveny standardní daňové zátěži, ${ }^{32}$ na druhé straně se stalo svébytným lenním dominiem s vysokou mírou autonomie, která byla ze strany císařského dvora bezvýhradně respektována. Do tohoto statu quo prakticky nijak nezasáhlo povýšení Frýdlantského knížectví na vévodství, k němuž došlo 4. ledna 1627.33 Právní podstata nedoznala novým diplomem žádné reálné změny a šlo vlastně znovu jen o „dorovnání“ statutu území s titulaturou generalissima, který byl vévodou již od léta 1625, kdy mu císař propůjčil právo psát se „Herzog zu Friedland“. ${ }^{34}$ Jinými slovy, tak jako bylo vytvořeno Frýdlantské knížectví pro knížete frýdlantského, bylo nyní s odstupem půl druhého roku vytvořeno vévodství pro vévodu. Albrecht a primogenitura jeho mužských potomků měli nadále nově užívat titulu ,panující vévoda z Frýdlantu“. Do privilegia, vydaného opět ve formě pergamenové knihy v červené sametové vazbě s přivěšenou (dnes chybějící) zlatou pečetí, německy, avšak z české kanceláře (a signovaném i stejnými podpisy), jsou ostatně doslovně inkorporovány i shora citované textové pasáže vztahující se na rozsah vrchních královských kompetencí.

Jisté upřesnění pak přineslo ještě privilegium z 11. května 1627, jímž panovník potvrdil, že veškeré soudnictví v civilních i trestních záležitostech má být ve Frýdlantsku konáno pouze před vévodským tribunálem a odvolání mohou být podávána pouze samotnému vévodovi. ${ }^{35}$ Obyvatelé vévodství tak byli výslovně vyňati z jurisdikce českých zemských orgánů a definitivně pozbyli jakékoliv (i do té doby ostatně spíše teoretické) šance hledat spravedlnost u císaře jakožto vrchního lenního pána. Frýdlantsko tak nabylo úplné autonomie soudní, přičemž osobní působnost tamních orgánů byla ještě dále rozšířena 14. února 1628 , kdy Ferdinand II. vztáhl jejich jurisdikci i na všechny osoby, které se budou na území vévodství nacházet. ${ }^{36}$ De facto tak byl prosazen princip teritoriality frýdlantského práva, který samozřejmě dále podpořil autonomii „št’astné země“. Ta mohla být ještě podstatně zřetelnější, pokud by se bývalo podařilo dotáhnout projekt vlastního frýdlantského zemského zřízení, na kterém podle Valdštejnových pokynů pracoval kancléř Ilgen. ${ }^{37}$

Výše provedený výklad byl nutný k tomu, aby bylo zcela patrné, že jakkoliv Frýdlantské vévodství formálně zůstávalo součástí Českého království, faktická míra jeho autono-

32 Srovnej např. „Vejpis kvitanci““ císařského rady a místodržícího mincmistrovského úřadu Štěpána Beníka z Petrštorfu ze zaplacení „,zbírky k př́ijezdu J[eho] M[ilosti] c[ísařské]“v roce 1627, či další kvitanci téhož císařského úředníka z roku 1628. RAV, Valdštejniána, i.č. 2650, sign. XII-C2; VL, sign. A 56a, kart. 3, fol. $31 \mathrm{r}-31 \mathrm{v}$.

33 RAV, Listiny, sign. N-18, i.č. 33; SAL, kniha č. 26, i.č. 11, fol. 661r - 668v.

34 Originál tohoto diplomu není dochován, jeho text se neobjevuje ani v salbuchách. Nepodařilo se ho objevit ani v říšských šlechtických aktech (Reischsadelsakten), uložených v Österreichisches Staatsarchiv Wien, Allgemeines Verwaltungsarchiv, při badatelském pobytu financovaném z IRP UK v listopadu 2013. Zmínka o povýšení na vévodu s datem 13. června 1625 se ovšem činí v citované listině o povýšení Frýdlantska na vévodství v lednu 1627.

35 RAV, Listiny, sign. N-20, i.č. 35; SAL, kniha č. 40, i.č. 17, fol. 68r - 70v. Ferdinand o tom následně zvláštními listy informoval i zemské úředníky - viz intabulovaný text v DZV 621, fol. D 6v - D 7r a opisy tohoto listu v české i německé verzi ve VL, sign. F 67/6, kart. 26, fol. 204r - 209v, 215r - 218r, 220r - 223r.

36 RAV, Listiny, sign. N-25, i.č. 40; SAL, kniha č. 40, i.č. 17, fol. 157r - 161r. Zároveň císař určil způsob přijímání léna vévodů z Frýdlantu a povolil, aby všechny královské patenty byly vévodům z Frýdlantu oznamovány zvláštním listem.

37 K tomu blíže STARÝ, Frýdlantské vévodství a jeho státoprávní postavení v rámci České koruny, s. $142-144$. 
mie byla velmi značná. Ve skutečnosti se jednalo o území prakticky svrchované, v němž mohl Valdštejn vládnout zcela dle své libovůle, ${ }^{38}$ a prakticky jediným významným omezením byla $\mathrm{z}$ jeho pohledu povinnost účastnit se v odpovídající míře na daňovém zatížení českých stavů. Součástí jeho libovůle také zůstávalo udílení jednotlivých statků uvnitř vévodství jako léna, stricto sensu s prrihlédnutím k lennímu charakteru celého jeho dominia jako podléna.

Frýdlantská lenní soustava rovněž dosud nepřitáhla intenzivnější pozornost ani právní, ani obecné historiografie. Východiskem k jakýmkoliv stručným a zjednodušeným výkladům o ní (jimž se v té či oné míře nevyhne žádná z Valdštejnových biografií) tak dodnes zůstávají především dvě práce Bílkovy z poslední čtvrtiny 19. století. ${ }^{39}$ Poněkud podrobněji jsou podchyceny pouze tzv. starolenní frýdlantské statky, tedy drobné, původem středověké lenní statky vázané $\mathrm{k}$ frýdlantskému hradu, jimž věnoval (ovšem v širším časovém rámci) soustavnější pozornost Rudolf Anděl. ${ }^{40} \mathrm{~V}$ poslední době se také objevilo několik speciálních studií zaměřených na dějiny jednotlivých lenních statků v době Valdštejnově. ${ }^{41}$

38 Literaturou pravidelně opakovanými doklady jeho absolutistického stylu vlády jsou nekompromisní vměšování do všech vnitřních záležitostí vévodství či bezohledný postup proti znelíbivším se úředníkům. Na žádost frýdlantské šlechty o zachování privilegií odpověděl Albrecht v roce 1624 stroze, že nemíní tolerovat žádnou „Svobodnou republiku“. POLIŠENSKÝ - KOLLMANN, Valdštejn. Ani císař, ani král, s. 78. K Valdštejnovu stylu vlády viz též STARÝ, Absolutismus „,na zelené louce“, s. 249-258; v širším kontextu TÝŽ. Political and Administrative System of Waldstein's Lands, s. 61-69.

39 BÍLEK, Dějiny konfiskaci v Čechách po r. 1618, s. 765-767 a 790-813; TÝŽ, Beiträge zur Geschichte Waldstein's, s. 58-91.

40 Zejména ANDĚL, R. Albrecht z Valdštejna a ,jeho“ lenní šlechta na frýdlantském panství. In: FUČÍKOVÁ, E. - ČEPIČKA, L. (eds.). Albrecht z Valdštejna. Inter arma silent musae? Praha: Academia, 2007, s. 201-206; TÝŽ. Frýdlantská lenní šlechta a obraz její existence v umělecko-historických památkách. Sbornik Severočeského muzea, Historia, 1986, 8, s. 23-44; TÝŽ. Hospodářská situace drobných šlechtických statků na česko-lužickém pomezí v XVII. století. Sborník Pedagogické fakulty v Ústí nad Labem, rada historická, 1971, s. 61-134; TÝŽ. Lenní statek Ves na Frýdlantsku v první polovině XVII. století. Sbornik Severočeského muzea, společenské vědy - historie, 1966, 5, s. 107-121; TÝŽ. Lesk a bída „nové“ drobné pobělohorské šlechty, Rodina Pülcherů na lenním statku Loučná na Frýdlantsku. Fontes Nissae, 2002, 3, s. 7-36; TÝŽ. Příspěvek k problematice životní a kulturní úrovně drobné šlechty na Frýdlantsku v 17. století. Z minulosti Děčínska a Českolipska, 1977, 3, s. 101-119; TÝŽ. Rybníkářství na statcích frýdlantské lenní šlechty v 16. a 17. století. Sborník Severočeského muzea, Historia, 1988, 9, s. 33-52; TÝŽ. Šlechtičny na frýdlantských lenních statcích v první polovině 17. století. In: BŘEZINA, L. - KONVIČNÁ, J. - ZDICHYNEC, J. (eds.). Ve znameni zemi Koruny české. Sborník k šedesátým narozeninám profesorky Lenky Bobkové. Praha: Casablanca, 2006, s. 513-528; TÝŽ. Tři právní př́ipady z dějin frýdlantské lenní šlechty v 17. století. Sborník Severočeského muzea, Historia, 1984, 7, s. 73-88 atd. V obecnější rovině též BELLING, V. Lenní šlechta na Frýdlantsku ve vrcholném a pozdním středověku. In: BŘEZINA, L. - KONVIČNÁ, J. - ZDICHYNEC, J. (eds.). Ve znameni zemi Koruny české. Sbornik k šedesátým narozeninám profesorky Lenky Bobkové. Praha: Casablanca, 2006, s. 499-512. Pojem „starolenní statky“ je dobový, objevuje se např. v soupise lén z března 1634, uloženém ve VL, sign. F 67/26, kart. 40, fol. 536v.

41 Metodické zamyšlení nad optimálním způsobem zpracování jednotlivých statků publikoval STARÝ, M. Frýdlantská léna v Českém ráji a jejich držitelé (stručný přehled a metodologické zamyšlení). In: Šlechtické rody a jejich sidla v Českém Ráji. Z Českého Ráje a Podkrkonoši - supplementum, 2009, 13, s. 281-286. Podle navrženého vzoru byly prozatím zpracovány dějiny statku Mladějov. TÝŽ. Frýdlantské léno Mladějov a jeho držitelé. Časopis Národního muzea. Řada historická, 2014, roč. CLXXXIII, č. 1-2, s. 3-18. K dějinám dalších drobných (nikoli pouze lenních) statků na Frýdlantsku viz dále TÝŽ. Konec rodu Semínů ze Semína. Z Českého ráje a Podkrkonoší, 2013, 26, s. 11-36; TÝŽ. Soupis obyvatel vsi Bukovina u Čisté v materiálech frýdlantské dvorské komory. Genealogické a heraldické listy, 2013, roč. XXXIII, č. 1, s. 50-63; TÝŽ. Vendito ut empto ut vendito...? Statek Albrechtice jako součást Valdštejnova Frýdlantska. In: KNOLL, V. - VALEŠ, V. (eds.). Naděje právní vědy. Býkov 2010. Plzeň: Aleš Čeněk, 2013, 
Navzdory těmto dílčím sondám je nepochybné, že prostor pro další výzkum je dosud velmi široký a množství archivních materiálů, čekajících na zpracování a zpřístupnění, takřka nepřeberné.

Skutečnost, že Valdštejn část získaných statků znovu postoupil, byt' si nad nimi podržel lenní svrchovanost, hodnotili někteří starší historici spíše skepticky. Již Josef Janáček ale upozornil, že zdání, ,jako by Valdštejn vnějšímu efektu obětoval hospodářské perspektivy svého knížectví“, je víceméně zavádějící a že objektivně nebylo možné „,v krátké době vybudovat na tak rozsáhlém území hospodářsky jednolitý celek“.42 Ve skutečnosti je tak Valdštejnův postup nutno vnímat jako po všech stránkách dobře promyšlený a v mnoha směrech efektivní. Císařský generalissimus takto utužoval závislost celé řady významných důstojníků na své osobě, vedle toho budoval svébytnou šlechtickou komunitu, z níž mohl čerpat při obsazování nejrůznějších administrativních postů ve správě vévodství. Udílení lén přitom neznamenalo zásadní problém ani v rovině ekonomické - většinu statků museli jejich noví držitelé řádně zaplatit, Valdštejn si ponechal některá vrchní práva a přenesl náklady na správu těchto statků a související jurisdikci nad poddanými na jejich držitele.

Jak již bylo uvedeno, existovaly jako samostatná skupina lén takzvané „starolenní“ statky, které byly de iure součástí frýdlantského panství a nepodléhaly proto zemským úřadům frýdlantského knížectví, resp. vévodství sídlícím v Jičíně, nýbrž frýdlantskému zámeckému hejtmanovi. Jednalo se skutečně o malé až nepatrné državy, ve většině případů ani neobjímající celou jednu vesnici - naopak v řadě vsí na Frýdlantsku bylo takových lenních držav několik. Poté, co se frýdlantského panství ujal, ponechal je Valdštejn vesměs původním vazalům, kteří byli politicky i ekonomicky příliš bezvýznamní na to, aby se mohli ve stavovském povstání nějak významněji kompromitovat. ${ }^{43}$ Zajímavé je, že evangelické vyznání těchto šlechticů, př́ibuzensky i majetkově vydatně provázaných se sousední Lužicí, tu nepředstavovalo významnější překážku.

Naproti tomu nově vytvořená léna byla vesměs konstruována jako hospodářsky do značné míry soběstačné jednotky, které plus minus odpovídaly charakteru předbělohorských rytířských statků v Čechách. Pokud jde o návaznost na předchozí majetkoprávní vývoj, pak je nutno konstatovat, že byla velmi variabilní. V některých případech byly jako léno uděleny prakticky beze změn stabilní předbělohorské statky, docházelo ale i k nejrůznějšímu přeskupování majetku a nechybělo ani „rozparcelování“ původních větších dominií, přičemž jako příklad tu může sloužit především panství Český Dub, v předbělohorské době součást majetkového komplexu Smiřických.

s. 141-152. Pozoruhodnou biografí jednoho z leníků s jen relativně málo informacemi o jeho statcích je studie GAJDOŠÍK, P. Adam Vilém Schellart a lenní statky Albrechta z Valdštejna. Bezděz, 2012, 21, s. $67-84$.

42 JANÁČEK, Valdštejn a jeho doba, s. 288-289.

43 Většina z nich se ale zřejmě povstání okrajově zúčastnila v oddílu svého lenního pána Kryštofa z Redernu, jak o tom svědčí výzva dochovaná v SOA Litoměřice, pobočka Děčín, fond Historická sbírka (Rodinný archiv Clam-Gallasů), kart. 474, sign. XXII/5, i.č. 12. K osobě Kryštofa, který byl za svou účast potrestán poměrně přísně konfiskací všeho majetku viz SVOBODA, M. Kryštof II. z Redernu, pobělohorský exulant. In: HRUBÁ, M. (ed.). Vira nebo vlast? Exil v českých dějinách raného novovéku. Ústí nad Labem: Albis international, 2001, s. 222-237; TÝŽ. Redernové v Čechách. Nalézání zapomenutých přiběhů 16. a 17. věku. Praha: Univerzita Karlova v Praze, Filozofická fakulta - Togga, 2011, s. 269-319. 
Valdštejnovy vazaly lze rámcově rozdělit do pěti (nikoli nevyhnutelně zcela disjunktních) skupin. ${ }^{44} \mathrm{~V}$ prvé řadě to byli jeho př́buzní. Z nich na prvním místě je samozřejmě nutno jmenovat vzdáleného bratrance a později i švagra Maxmiliána z Valdštejna, jehož císařský generalissimus také designoval jako svého nástupce. Ten držel nejrozsáhlejší komplex statků Mnichovo Hradiště - Klášter - Svijany - Zvířetice, k nimž na sklonku existence Frýdlantského vévodství obdržel ještě Grabštejn. Druhý velký komplex statků Lomnice - Štěpanice - Branná držel od roku 1632 další Albrechtův švagr, hrabě Ota Bedřich z Harrachu. Pokud jde o další blízké příbuzné z rodu Valdštejnů, z řady Valdštejnových bratranců obdržel Jan Kryštof Javorník (Heřmanovy Sejfy), Hanibal Miletín, Zdeněk Olešnici a Sloupno, a Kristián nejprve Návarov a posléze Druzcov a Křenovy. Vzdálený př́buzný a doyen valdštejnského rodu Jan Vojtěch dostal drobný statek Roven̆, a nakonec se skromného zaopatření dočkal i synovec Jan Kryštof starší, zajatý v dánských službách a nějakou dobu vězněný na Hrubé Skále. Jemu byl postoupen poplužní dvůr ve Vísce v tomto př́padě ovšem nikoli jako léno, nýbrž pouze k doživotnímu užívání. Lenní statek Mladějov držel krátce bratranec z matčiny strany Jan Albrecht Slavata z Chlumu.

Patrně nejčastěji skloňovanou skupinu leníků tvořili Valdštejnovi důstojníci, jejichž zásluhy generalissimus odměňoval a věrnost si pojišt'oval mimo jiné právě i udělováním různě rozsáhlých majetků v rámci svého vévodství. ${ }^{45} \mathrm{Z}$ hlediska subordinačního šlo o skupinu poměrně pestrou, v níž elitu tvořila početná skupina plukovníků (Mikuláš Des Fours, Jan Ludvík Isolano, Adam Vilém Schellart), vedle nich tu ale byli i další členové důstojnického sboru, a to již od hodnosti rytmistra. Ve dvou prŕípadech prodal vévoda lenní statek vdově, resp. (nezletilému) synovi zasloužilého důstojníka. Nutno podotknout, že co do počtu poddanských usedlostí tvořily důstojnické statky rozhodně největší podíl, dosahující v souboru všech frýdlantských lén téměř 80 \%. Stejně tak je ale třeba dodat, že toto vysoké číslo je do značné míry ovlivněno tím, že i dva Valdštejnovi švagři (Maxmilián z Valdštejna a Ota Bedřich z Harrachu) byli veliteli vlastních pluků. I bez započtení jejich rozsáhlých majetkových komplexů se ale na zbožích ostatních členů důstojnického sboru habsburské, resp. Valdštejnovy armády nacházela téměř polovina usedlostí. ${ }^{46}$

Př́stup k lenním statkům se nabízel také těm, kdo se angažovali ve správě frýdlantského vévodství, popřípadě při Valdštejnově dvoře. Tak prakticky zároveň se jmenováním do úřadu zemského hejtmana koupil Gerhard Taxis panství Valečov, dva statky získal postupně regent (komorní prezident) Jeroným Bukovský z Neudorfu. Mezi držiteli lenních statků byli další reprezentanti ústřední zeměpanské správy, kancelářští i komorní radové (k prvním patřili Hanibal z Valdštejna, Jakub Reichard Heuster, ${ }^{47}$ Pavel Cornazzani, dr. Adam Neff z Achnitz, v komoře působili Jan Kuneš z Lukavec a v roli sekretáře také

44 Další přehled má spíše ilustrativní charakter a z kapacitních důvodů je v něm abstrahováno na podrobný poznámkový aparát.

45 K této skupině naposledy podrobně STARÝ, M. Můj velitel, můj pán. Frýdlantské lenní statky v rukou Valdštejnových důstojníků. Bohemiae Occidentalis Historica, 2019, roč. V, č. 2, s. 135-155.

46 Blíže STARÝ, Můj velitel, můj pán, s. 145-150.

47 Jméno hejtmana a později plukovníka Jakuba Reicharda Heustera se v dobových písemných pramenech objevuje v celé řadě verzí (Heuster, Heustern, Heistra, Heistern atd.). Např́klad MAŠEK, P. Šlechtické rody v Čechách, na Moravě a ve Slezsku od Bílé Hory do současnosti. Díl I. Praha: Argo, 2008, s. 342, uvádí tvar „Heistern“. Při udělení inkolátu jeho bratru Janovi, který po něm zdědil české majetky, je v roce 1641 použito tvaru „Heister“. SAL, kniha č. 54 , i.č. 22 , fol. $287 \mathrm{r}-289 \mathrm{v}$. V textu této studie je volena varianta „Heuster“, která odpovídá textu př́íslušné kupní smlouvy. 
liberecký měšt’an Jan Graff, nobilitovaný s predikátem z Ehrenfeldu a obdarovaný statkem Borovnička), vedle nich také někteří hejtmané komorních statků (např. bělskému hejtmanovi Dětřichovi ze Staršedl byly uděleny Kluky nedaleko od Bělé). Z Valdštejnových úředníků dvorských byl zároveň jeho vazalem nejvyšší hofmistr Kryštof Pavel hrabě z Lichtenštejna-Kastelkornu, nejvyšší komorník, výše zmíněný vévodův švagr Ota Bedřich hrabě z Harrachu, a nejvyšší stř́ibrník (komorník nad stříbrem) Ladislav Licek z Rýzmberka. Z dalších, méně exponovaných členů Valdštejnova „hofštátu“ lze jmenovat např. mundšenka Volfa Ladislava ze Šlejnic či kraječe Augustina Morando. Podrobnější sledování by si přitom jistě zasloužila kauzalita těchto př́ípadů. Jinými slovy by bylo vhodné prověřit, zda byla léna udělována osvědčeným služebníkům, nebo zda spíše byli do správních i dvorských funkcí povoláváni ti, kdo již z dřívějška byli k Valdštejnovi připoutáni lenním slibem. S největší pravděpodobností šlo přitom o uplatnění obou variant, otázkou je, v jakém poměru.

V některých případech posloužilo udělení lenního statku Valdštejnovi k vyřešení jeho závazků vůči různým osobám. Př́ikladem par excellence mohou být dcery Viléma Miřkovského z Tropčic, které po svém otci zdědily Vrchlabí. To Valdštejn koupil již v roce 1624, z kupní ceny 110000 kop míšeňských grošů ale zůstal 90000 kop dlužen a do jejich zaplacení měla rodina Miřkovských dále statek držet (jako zástavu). ${ }^{48}$ Vzhledem k tomu, že Valdštejn nebyl v kontextu svých dalších závazků schopen či ochoten takto velkou částku uhradit, řešil vše po Vilémově smrti tím, že jeho dcerám postoupil v červnu 1629 jiné lenní statky. Rosina Zilvárová obdržela Bělohrad, Kateřina Valdštejnská Miletínek a Alžběta Stošová Holovousy. Všechny tři převody byly formálně koncipovány jako prodej léna, zároveň ale došlo k započtení pohledávek a kupní cena byla všem třem Vilémovým dcerám stržena $\mathrm{z}$ jejich dílu pohledávky zděděné po otci. Zcela bez nutnosti platit získal také Zdeněk z Valdštejna Sloupno, a to jako kompenzaci za pohledávku své choti Anny Marie Libštejnské z Kolovrat. Ta činila přesně 16000 kop míšeňských grošů, za které mu bylo Sloupno prodáno. Také někteří důstojníci obdrželi léno víceméně na úhradu svých pohledávek a museli zaplatit jen větší či v mnoha př́padech menší část kupní ceny.

Naproti tomu v př́padech, kdy Valdštejn vykoupil enklávu narušující územní celistvost Frýdlantska a ponechal ji do vyplacení kupní ceny původním držitelům (tak, jak tomu původně bylo $\mathrm{v}$ případě shora řečeného Vrchlabí), nevytvářel se klasický lenní vztah, ale jednalo se o zástavní držbu frýdlantského komorního statku. ${ }^{49}$ Výjimku v tomto směru představuje pouze několik málo statků: Lukavec, koupený od bratrů Stařimských z Libštejna a následně jim znovu prodaný, Miletín, který Valdštejn koupil v květnu 1625 od Hanibala z Valdštejna a jeho nezletilých bratrů, a jeho část pak v červenci skutečně prodal Hanibalovi jako frýdlantské léno, a do jisté míry též Loukovec, který Valdštejn koupil jako konfiskát a prodal ho po roce původnímu majiteli Alešovi Berkovi z Dubé.

48 RAV, Valdštejniána, i.č. 2706, sign. XIII-S2 a i.č. 2711, sign. XIII-Y2; DZV 141, fol. M 23r - M 23v; DZV 292, fol. O 13r - O 15r. Rozsah panství zachycuje urbář z roku 1624, uložený v SOA Zámrsk, fond Velkostatek Vrchlabí, i.č. 592, kniha č. 171.

49 Na konkrétním př́kladu dokumentuje tuto právní konstrukci STARÝ, Vendito ut empto ut vendito...?, s. $141-152$. 
Také v těchto případech nepochybně k reálnému hrazení celé kupní ceny nedocházelo, ale vše se víceméně řešilo započtením. ${ }^{50}$

Konečně zbývá pátá, do jisté míry „zbytková“ kategorie leníků, kam lze zařadit ty šlechtice, kteří se do držby frýdlantského lenního statku dostali z jiného důvodu, respektive u nichž nelze žádný ze shora uvedených důvodů za daného stavu poznání identifikovat.

Navzdory zdánlivě dlouhému (a zdaleka ne úplnému) soupisu jmen vazalů uvedených v textu výše je třeba zdůraznit, že většina frýdlantského státečku zůstala po celou dobu jeho existence pod př́mou Albrechtovou vládou. Rozsah lenních statků rozhodně nebyl zanedbatelný, rozlohou, počtem obyvatel i ekonomickým potenciálem však tvořila léna vždy jen menší část „št’astné země“. Součástí komorních statků zůstala všechna velká, hospodářsky silná města, která měla v počtu osmi (Jičín, Frýdlant, Česká Lípa, Hostinné, Turnov, Český Dub, Bělá pod Bezdězem a Liberec) podle připravovaného zemského zřízení tvořit městský stav vévodství. ${ }^{51}$ Také z dochovaných údajů berních je omezený potenciál lenních statků dosti patrný. Pokud se v celém Frýdlantsku nacházelo kolem 12000 poddanských usedlostí („,osedlých“), 52 pak na statcích lenních jich bylo něco přes 4000.53 Počet těchto statků mírně kolísal, řádově se ale pohyboval v desítkách. ${ }^{54} \mathrm{Z}$ hlediska dalšího studia se tak jedná o poměrně objemný, vnitřně diferencovaný a bezpochyby pozoruhodný soubor. Předkládaná práce si přitom rozhodně neklade a s ohledem na svůj rozsah ani nemůže klást za úkol zpracovat ho syntetickým způsobem. Její cíl je naopak velmi úzký a specifický: provést analýzu kupních smluv, na jejichž základě byly majetkové komplexy uvnitř Frýdlantského knížectví (vévodství) převáděny do lenní držby různých osob, a poukázat na to, že ačkoliv tyto kontrakty vznikaly v poměrně úzkém časovém intervalu na půdě jediného administrativního orgánu (tj. frýdlantské dvorské kanceláře, sídlící v Jičíně)

50 U Loukovce je otázkou, nakolik bylo započtení úplné. Je totiž třeba dále prověřit, zda Valdštejn při koupi statku od císaře nepřevzal povinnost vyrovnat se s Berkou, odsouzeným ke ztrátě nikoli všeho, nýbrž jen poloviny majetku.

51 RAV, Valdštejniána, i.č. 2338, sign. I-C, fol. 175r - 214v; VL, sign. F 67/6, kart. 26, fol. 136r - 162v; CZOERNIG, K. J. Albrecht von Waldsteins urkundlich erwiesener Versuch, sein Herzogthum Friedland als ein selbständiges Gebiet zu organisieren, und von der Krone Böhmens abzureissen. Monatschrift der Gesellschaft des vaterländischen Museums in Böhmen, December 1829, III. Jahrgang, s. 454, a TÝZ̆. Versuch Albrecht's von Waldstein, eine ständische Verfassung in seinem Herzogthume Friedland einzuführen. Taschenbuch für die vaterländische Geschichte, Neue Folge, I. Jahrgang. Stuttgart: Franckh, 1830, s. 37-38.

52 Toto číslo uvádí italsky psaný odhad lidnatosti Čech z roku 1631, otištěný v KOLLMANN, H. K úbytku obyvatelstva v království Českém za války třicetileté. Český časopis historický, 1910, roč. XVI, č. 1, s. 52-53. V roce 1626 se podle kvitance Štěpána Beníka z Petrštorfu, místodržícího nejvyššího mincmistrovství na území knížectví nacházelo 11762 usedlostí, z nichž ovšem desetina byla bud' pustá, nebo pohořelá. VL, sign. A 56a, kart. 3, fol. 31r - 31v; RAV, Valdštejniána, i.č. 2650, sign. XII-C2.

53 Soupis zpracovaný krátce po Valdštejnově zavraždění zachycuje na lenních panstvích 4224 osedlých, Z nich pustých či pohořelých 744. Jeho česká verze je uložena v VL, sign. F 67/26, kart. 40, fol. 536r - 536v, 540r - 540v, německý opis se nachází v Österreichisches Staatsarchiv (=ÖStA) Wien, Haus-, Hof- und Staatsarchiv, fond Handschriftensammlung, sign. W 120, s. 245-248. Blíže STARÝ, M. Soupis osedlých na lenních statcích frýdlantského vévodství na sklonku jeho existence. Časopis Společnosti prátel starožitností českých, 2014, roč. CXXII, č. 2, s. 87-104.

54 Uvedený soupis z roku 1634 zachytil 45 lenních statků, k nimž je zapotřebí připočítat více než 20 drobných manských držav, které byly součástí panství Frýdlant. Nedatovaný přehled, uložený v VL, sign. F 67/27, kart. 42, fol. $384 \mathrm{r}-384 \mathrm{v}$, uvádí 23 vazalů na těchto „starolenních“ statcích (držitelů „nových“ lén je tu zachyceno 40). 
a ačkoliv byly směřovány ke stejnému účelu, je jejich textace a konstrukce jednotlivých smluvních ustanovení nečekaně variabilní a pestrá. Což může být námětem k další úvahám právněhistorickým stejně jako diplomatickým.

\section{Kupní smlouvy k lenním statkům - přehled}

Když psal Josef Janáček ve svém syntetickém díle pasáž o frýdlantských lénech, komentoval postoupení statků v odhadní ceně dosahující téměř čtvrt milionu rýnských zlatých bratranci Maxmiliánovi slovy, že „,při Valdštejnově známé lakotě to byl vskutku nečekaný knížecí dar“. 55 Tento despekt se nicméně zdá poněkud přehnaný. Stejně tak bez jakékoliv protihodnoty obdržel své statky i mladý Ota Bedřich z Harrachu, kterého jistě nelze podezírat, že se jakýmkoliv způsobem podílel na „nekalých machinacích“, do nichž se podle Janáčka Maxmilián namočil. Také několik dalších statků Valdštejn daroval, o čemž vypovídají příslušné dokumenty, jejichž koncepty či opisy byly v registratuře označovány termínem „Donationsbrief“, nebo „Schenkungsbrief“. 56 Samozřejmě, nelze vyloučit, že darováním mohly být kompenzovány nějaké starší pohledávky novopečených leníků. Nezdá se to ale pravděpodobné, nebot' v těchto prrípadech byla situace řešena formou koupě, s tím, že prríslušná pohledávka se promítla do ustanovení týkajících se uhrazení kupní ceny (viz dále). Darovací listy lze tedy spíše skutečně chápat jako projevy velkorysosti knížete, u něhož se alespoň občasné její projevy v rámci udržování obrazu nadstandardní až okázalé aristokratické reprezentace legitimně očekávaly. Ostatně i v textu těchto darovacích listů se zdůrazňuje, že jsou statky darovány ,au $\beta$ besondern fürstlichen Gnaden, Mildigkheit, gnädiger Erkhäntnü $\beta$ und aigener Bewegnu $\beta “, 57$ resp. ,,au $\beta$ fürstlichen Mildigkeitt unnd gnediger Erkannthnu $\beta$, eigener Bewegnu $\beta$ “. .58

Tomáš Václav Bílek vymezil jako zvláštní skupinu frýdlantských lén statky „od Waldšteina skoupené, ale nezaplacené a dřívějším držitelům jich v léno k užívání zastavené a ponechané“. ${ }^{59}$ Při nedávném podrobném zpracování dějin dvou z nich bylo nicméně zjištěno, že jejich držba neměla lenní charakter a že se jednalo pouze o zástavu, jež mohla být kdykoliv s roční výpovědí vyplacena. ${ }^{60}$ Bývalí majitelé (v některých př́ípadech jejich prŕibuzní) za ně lenní slib neskládali, což bylo vzhledem k dočasnému charakteru nastoleného právního vztahu vcelku pochopitelné. Více než výmluvná je skutečnost, že tyto statky nefigurují ve shora zmíněném soupisu lenních statků, pořízeném po Valdštejnově zavraždění. ${ }^{61}$ Zajímavou vnější odlišnost je možno spatřovat také v tom, že příslušné

55 JANÁČEK, Valdštejn a jeho doba, s. 288.

56 Tyto koncepty a opisy jsou uloženy v VL, sign. F 67/27, kart. 42, fol. 6r - 8v, 11r - 13r (Lomnice a další statky Otovi Bedřichovi z Harrachu), 16r - 17r (Domoslavice Františkovi de Jacobo), 19r - 21r, 24r - 24v, 38r, 239r - 241r (část panství Bělohrad Jindřichovi ze Saint Julienu), 34r - 35r (Borovnička Janu Graffovi), 36r - 37r, 39r - 39v (Bílá Třemešná Ladislavovi Lickovi z Rýzmburka), 40r - 45r (Velehrádek a Červené Poličany Janu Pieronimu). Opisy listů na Borovničku, Velehrádek a Červené Poličany, část Bělohradu, Domousnice a Lomnice a Branná jsou též v NA Praha, fond Sbírka rukopisů B, i.č. 15, sign. B 16, fol. $89 \mathrm{r}-90 \mathrm{r}, 98 \mathrm{r}-99 \mathrm{r}, 102 \mathrm{r}-104 \mathrm{r}, 129 \mathrm{r}-130 \mathrm{v}, 139 \mathrm{r}-140 \mathrm{v}$.

57 Tak v listu pro Otu Bedřicha hraběte $\mathrm{z}$ Harrachu.

58 Tak v listu pro Jana Graffa.

59 BÍLEK, Déjiny konfiskacív Čechách po r. 1618, s. 808.

60 Srovnej STARÝ, M. Konec rodu Semínů ze Semína. Z Českého ráje a Podkrkonoší, 2013, 26, s. 11-36; TÝŽ. Vendito ut empto ut vendito...?, s. 141-152.

61 Zdánlivou výjimkou jsou Vinary „,pánův Rašínův“. Nejedná se zde ale zřejmě o statek Vinary, koupený v roce 1628 od bratří Adama a Jana Rašínů a vzápětí postoupený jejich matce, která tu měla zapsané 
smlouvy o postoupení statků jsou jazykově české, zatímco kupní smlouvy, jimiž byla prodávána léna, jsou zásadně psány v jazyku německém. Jistou podobnost s klasickými lény lze naproti tomu spatřovat v omezeních držitelů, která si Valdštejn jako zeměpán v obou prípadech smluvně vyhrazoval.

Jak bylo uvedeno výše, u několika statků (Lukavec, Miletín, do jisté míry i Loukovec) sáhl Valdštejn skutečně k tomu, že koupený statek vzápětí přenechal původnímu držiteli jako léno. V těchto prípadech se to ale dálo obvyklou kupní smlouvou. Tyto statky Bílek navíc uvádí v souboru „klasických“ frýdlantských lén.

Specifický př́pad reprezentuje de iure také držba statku Vlčice ze strany plukovníka Daniela Hebrona. Bílek řadí i Vlčice mezi léna s tím, že je Daniel dostal do zástavy minimálně na 30 let. ${ }^{62}$ Lenní charakter statku zdánlivě potvrzuje i skutečnost, že figuruje jako držba „paní Hebronový“, tj. Danielovy vdovy, v soupisu lenních statků, pořízeném krátce po Valdštejnově zavraždění. ${ }^{63}$ Avšak v konceptech a opisech zástavních listů z 9. ledna, resp. 5. června 1627 se o lenním vztahu mezi Albrechtem a Danielem nic neříká, a naopak, statek Vlčice je tu označen jako komorní zboží („Cammergut"“). ${ }^{64}$

Ve většině případů ovšem platilo, že lenní statky byly novým držitelům postupovány na základě uzavření kupní smlouvy, předpokládající zaplacení ceny, odpovídající odhadované hodnotě statku. Tuto skutečnost lze ovšem jen stěží vnímat jako projev generalissimovy lakoty, ale jako projev racionálního ekonomického uvažování. Naopak, jak bude dále doloženo, v některých případech kupujícím uhrazení části kupní ceny jako zvláštní projev vstř́ícnosti odpustil. ${ }^{65}$

Kupní smlouvy, jimiž Albrecht z Valdštejna svým př́ibuzným, úředníkům, služebníkům, věritelům či dalším osobám frýdlantské lenní statky přenechával, představují poměrně početný soubor konkrétních právních jednání, která se přímo nabízejí k formální, systematické i obsahové analýze. ${ }^{66}$ Naštěstí se také jedná o soubor, který poměrně dobře př̀konal jak poněkud chaotické období, které Frýdlantsko postihlo po generalissimově politickém pádu a fyzické likvidaci, tak i nástrahy věků pozdějších. V současné době se při poznávání těchto smluv lze opř́it o dva prvořadé zdroje.

Prvním z nich je sbírka písemností označená jako Valdštejniána, tvořící součást fondu Rodinný archiv Valdštejnů ve Státním oblastním archivu Praha. Zde jsou v šestnácti konvolutech svázány originály i opisy nejrůznějších rodinných písemností, z nichž nemalá část se vztahuje právě k osobě Albrechta, respektive jeho vévodství. Ve svazcích XIII až XV je soustředěno celkem 34 originálů kupních smluv, v nichž vévoda vystupuje jako prodávající a předmět prodeje přechází do lenní držby kupujícího, vedle toho jsou dva opisy ukryty ve svazku I (viz dále Tab. I).

vdovské věno, ale o menší statek v téže vsi, který byl snad v roce 1633 skutečně převeden v léno. BÍLEK, Déjiny konfiskací v Čechách po r. 1618, s. 812-813.

62 BÍLEK, Dějiny konfiskaci v Čechách po r. 1618, s. 790-791.

63 VL, sign. F 67/26, kart. 40, fol. 536v.

64 VL, sign. F 67/26, kart. 40, fol. 47r - 48v, 57r - 58v, 60r - 61r, 62r - 63v. V lednu byla zástavní částka vyčíslena na 149000 rýnských zlatých, v červnu činila již „pouze“ 120000 zlatých. V obou případech platilo, že hotově měl Daniel složit 60000 zlatých a zbytek mu měl být započten za jeho vojenské služby.

65 Formálně se tak ovšem dělo odpovídajícím ponížením původně vyčíslené ceny přímo v kupní smlouvě.

66 Vedle toho také přinášejí četné informace využitelné při prohlubování znalosti regionálních dějin. 
Dotyčné smlouvy mají vnější podobu dvou papírových dvoulistů svázaných hedvábnou šňůrkou v rodových barvách Valdštejnů, tedy modrožlutou. Text zpravidla pokrývá první čtyřri stránky, v některých př́padech je ale v závislosti na zvolené velikosti písma a mezer poněkud delší, prrípadně až na šest či dokonce sedm stránek. ${ }^{67}$ Naopak stručněji a úsporněji psané smlouvy se v některých prŕípadech vešly na tři stránky. Na poslední popsané stránce jsou pak vždy přitištěné pečeti s papírovou krytkou - hned pod textem velká pečet' Valdštejna coby prodávajícího a v řadě pod ní menší pečeti (se společnou krytkou) kupujícího a dvou svědků, vždy v tomto pořadí. Všichni pečetitelé listiny také podepisovali. Zeměpán zpravidla vlevo přímo pod textem, částečně přes krytku orientovanou nakoso, ostatní pod svými pečetěmi. Na některých smlouvách (tvořících ovšem co do počtu menšinu) je na poslední popsané straně s pečetěmi v pravém dolním rohu připojen podpis sekretáře, který za vyhotovení listiny nesl odpovědnost. ${ }^{68}$

Druhým, ještě obsáhlejším pramenem poznání je rukopis označený signaturou B 16 a nazvaný „Contract-Buch der Verkäufe unter die Lehen des Herzogthums Friedland“, jenž se nachází v I. oddělení Národního archivu v Praze ve fondu Sbírka rukopisů B. ${ }^{69}$ Jedná se o papírovou knihu o rozměrech $24,5 \times 31 \mathrm{~cm}$ v polokožené vazbě, čítající 143 číslovaných a 7 nečíslovaných folií. Dva výstřižky přilepené na reversu předních desk ji charakterizují jako „moderní opis z rukopisu hraběte Hugona z Waldersdorfu v Řezně““, což přebírá i př́islušný inventár̆. ${ }^{70} \mathrm{Na}$ titulní stránce s názvem rukopisu (k němuž je pozdější rukou připojeno ,(1624-1633)“) je kulaté razítko s opisem ARCHIVUM REGNI BOHEMIAE 1902, opakující se pak ještě jednou o tři folia dále. Recta lichých folií jsou nicméně opatřena obdobným razítkem s datem 1899 dokládajícím, že se tento rukopis dostal do ústředního archivu země české již na sklonku 19. století. Dokazuje to i poznámka v pravém dolním rohu na přední stránce nečíslovaného třetího folia „coll. 11-16/3 99“ s nečitelným podpisem.

Existuje několik manuskriptů s popisem frýdlantských statků a reflexí jejich majetkoprávního vývoje, ${ }^{71}$ výše popsaný Walderdorffưv je ale jediný zaměřující se apriorně na poznání smluvních vztahů, do nichž Albrecht z Valdštejna se svými vazaly vstupoval. Je v něm obsaženo ne méně než 42 úplných opisů kupních smluv, vesměs chronologicky seřazených. K nim je možno přičíst další 4 dokumenty, rovněž zachycující podmínky koupě/prodeje lenních statků a v rukopise rovněž označené jako „Kaufcontract“. O smlouvy v pravém slova smyslu se ovšem nejedná, nebot' jde o konfirmační dokumenty vystavené jednostranně vévodskou kanceláří (o nich viz dále). Kromě toho bylo do rukopisu pojato i několik dalších právních aktů, které dokreslují majetkoprávní vývoj některých statků (jsou tu obsaženy opisy některých darovacích a zástavních listů, postoupení statků koupených

67 Na sedm stránek je rozepsána kupní smlouva na statek Hrubý Rohozec, datovaná 7. prosince 1624. RAV, Valdštejniána, i.č. 2735, sign. XIV-Th.

68 S ohledem na právněhistorické zaměření této práce je rezignováno na podrobnější diplomatický či paleografický popis smluv.

69 NA Praha, fond Sbírka rukopisů B, i. č. 15, sign. B 16.

70 VOLF, M. NA Praha, fond Sbírka rukopisů. Inventář skupiny B, nedatováno (pomůcka č. 122/II). Zjevně tu jde o drobné zkomolení jména autora původního rukopisu, za nějž lze bezesporu považovat německého historika hraběte Huga von Walderdorff (1828-1918), sídlícího na zámku Hauzenstein poblíž Řezna.

71 Uvést lze např́iklad další opis z Walderdorffova manuskriptu, uložený v NA Praha, fond Sbírka rukopisů B, i. č. 14, sign. B 15 (Beschreibung der friedländischen Lehengüter im Königreich Böhmen), či knihy z druhé poloviny 17. století, uložené ve VL, sign. F 67/26, kart. 39, knihy č. 18-20. 
Valdštejnem původním držitelům až do zaplacení kupní ceny, i dalších písemností). ${ }^{72}$ Platí přitom beze zbytku, že všechny smlouvy nacházející se ve Valdštejniánech jsou obsaženy i v rukopisu. Bohužel, autor v něm nezachytil zdroj převzatých informací, tedy provenienci originálů (opisů?), z nichž při své práci čerpal. Porovnáním opsaných textů s originály, jež jsou k dispozici ve Valdštejniánech, lze nicméně dospět k závěru, že rukopis B 16 představuje velmi spolehlivý zdroj a lze k němu bez obav přihlížet i v prŕípadech, kdy dotyčné smlouvy nejsou odjinud známy.

Vedle dvou uvedených zdrojů se lze s kupními smlouvami týkajícími se lenních statků frýdlantského knížectví (vévodství) setkat i v dalších archivních fondech. Z nich výjimečné postavení má nepochybně fond Valdštejniana, který vznikl po vzniku samostatného Československa sloučením písemností ústředních orgánů frýdlantského vévodství (dvorské kanceláře a dvorské komory) a registratury Valdštejnovy vojenské kanceláře z let 1625-1630, zařazených do té doby do fondu Stará manipulace pod signaturou F 67, s obdobnou registraturou z let 1631-1634, přechovávanou do té doby ve Vídni a našemu státu postoupenou v rámci archivní rozluky s Rakouskem. ${ }^{73}$ Zde jsou četné materiály k jednotlivým lenním statkům uloženy zejména v kartonu č. 42, soustřed’ujícím materiály opatřené subsignaturou F 67/27. Kupní smlouvy se tu objevují ve všech možných podobách - jako čistopisy, opisy i koncepty. ${ }^{74}$ Ve srovnání s rukopisem B 16 je tu obsažen jeden originální kontrakt

72 Konkrétně a v úplnosti se jedná o následující právní akty: Specifikace osob, příslušejících k lennímu statku Straníka Straníka z Kopidlna Horní Líšno (16. 11. 1629, fol. 8v - 9r), postoupení statku Vinary k užívání Anně Marii Rašínové z Onšova v nesplacené kupní ceně 14000 kop míšeňských grošů (23. 5. 1628, fol. $66 \mathrm{r}-68 \mathrm{r})$, postoupení statku Albrechtice k užívání Anně Kyjové z Gerštorfu v nesplacené kupní ceně 16000 kop míšeňských grošů (26. 6. 1628, fol. 69r - 70r), postoupení statku Jeřice k užívání Anně Alžbětě Myškové z Hodkova v částce 21500 kop míšeňských grošů, k němuž je připojen výčet předaných mobilií (20. 5. 1628, fol. 77r - 79v), darování statku Borovnička Janovi Graffovi z Ehrenfeldu (6. 3. 1627, fol. 89r - 90r), zástavní list na statek Vlčice Danielovi Hebronovi v částce 120000 rýnských zlatých s inventářem vybavení jednotlivých dvorů a ovčínů (9. 1. 1627, fol. 90r-94r), kvitance na 60000 rýnských zlatých dědicům Daniela Hebrona (10. 10. 1628, fol. 94v - 95v), zástavní list na statky Svijany, Klášter a Zvířetice v částce 300000 rýnských zlatých (9. 11. 1624, fol. 96r - 97v), darování statků Velehrádek a Červené Poličany Janu Pieronimu (10. 3. 1630, fol. 98r - 99r), darování expektance na lenní statek Třebňouševes a dvůr Rašín Zikmundovi Petrovi Adolfovi svobodnému pánu z Schönkirchen (23. 3. 1630, fol. 100r - 101v), darování části panství Bělohrad Jindřichovi ze Saint Julienu (23. 3. 1630, fol. 102r - 104r), směna statků Rohoznice a Bělohrad mezi Jindřichem ze Saint Julienu a Rosinou Zilvárovou z Tropčic (3. 5. 1630, fol. 123r - 124r), darování statku Domousnice Františkovi de Jacobo (13. 9. 1631, fol. 129r - 130v), darování panství Lomnice a Branná (Štěpanice) Otovi Bedřichovi Hraběti z Harrachu (6. 11. 1632, fol. 139r - 140v), povolení Jindřichovi ze Saint Julienu lovit na kartuziánských pozemcích (11. 5. 1633, fol. 141r - 141v), povolení libereckým tkalcům vybudovat cechovní (mistrovský) dům a dům pro tovaryše (14. 5. 1633, fol. 142r - 142v), osvobození jičínského hostince U Zlatého lva od ubytovací povinnosti (fol. 143r - 143v).

73 NA Praha, Valdštejniana, přehled materiálu a pomůcek k fondu, autorka Věra Beránková, Praha 1995 (strojopisný inventář), s. 1-2.

74 VL, sign. F 67/27, kart. 42, fol. 157r - 159r (kolacionovaný opis smlouvy na Chrastnou z roku 1628, datovaný 31. května 1634), 161r - 162r (jednostranný list o prodeji Lemberka Janu Rudolfovi Bredovi v roce 1633, čistopis s přitištěnou Valdštejnovou pečetí), 174r - 175v (smlouva na Stráž pod Ralskem z roku 1633, čistopis s přitištěnou Valdštejnovou pečetí), 178r - 179r (smlouva na Valečov z roku 1633, čistopis s přitištěnou Valdštejnovou pečetí), 180r - 182r (jednostranný list o prodeji Valečova Františkovi Marazzanimu v roce 1633, čistopis s přitištěnou, částečně odlomenou Valdštejnovou pečetí), 247r - 248r (koncept smlouvy na Kluky z roku 1629), fol. 249r - 250v (opis téže smlouvy), 261r - 261v, 268r - 268v (koncept smlouvy na Lukavec z roku 1630), 262r - 262v, 267r - 267v (opis téže smlouvy), 263r - 265v (originál téže smlouvy), 271r - 271Av (kolacionovaný opis smlouvy na Sloupno z roku 1630, vyhotovený v tomtéž roce), $272 \mathrm{r}-273 \mathrm{v}$ (koncept jednostranného listu o prodeji Sloupna v roce 1630), 277r - 278v (koncept téhož 
Tab. I. Chronologický přehled dochovaných kupních smluv na frýdlantská léna a jejich konvokace

\begin{tabular}{|c|c|c|c|c|}
\hline Datum & Statek & RAV, Valdštejniána & Rkp B 16 & $\begin{array}{l}\text { VL, F 67/27, } \\
\text { kart. } 42\end{array}$ \\
\hline $1624,26.1$. & $\begin{array}{l}\text { Loukovec, } \\
\text { Kostřice }\end{array}$ & & $1 r-2 r$ & \\
\hline $1624,29.1$. & Olešnice & i.č. 2707, sign. XIII-T2h & $3 r-4 r$ & \\
\hline $1624,29.1$. & Třebňouševes & i.č. 2726 , sign. XIV-Kh & $5 r-6 r$ & $330 \mathrm{r}-331 \mathrm{v}$ \\
\hline $1624,7.2$ & $\begin{array}{l}\text { Horní Líšno } \\
\text { (Slavíkovec) }\end{array}$ & i.č. 2733 , sign. XIV-Rh & $7 r-8 r$ & \\
\hline $1624,24.2$. & Roveň & i.č. 2734 , sign. XIV-Sh & $9 r-10 v$ & \\
\hline $1624,27.2$ & $\begin{array}{l}\text { Bílá Třemešná, } \\
\text { Velehrádek }\end{array}$ & & $11 \mathrm{r}-12 \mathrm{v}$ & $79 r-80 v$ \\
\hline $1624,4.3$ & $\begin{array}{l}\text { Český Dub } \\
\text { (díl }-6 \text { vsí) }\end{array}$ & i.č. 2736, sign. XIV-Uh & $14 r-15 r$ & \\
\hline $1624,4.3$ & Nudvojovice & i.č. 2728 , sign. XIV-Mh & $16 r-17 r$ & \\
\hline $1624,11.3$ & Návarov & i.č. 2725 , sign. XIV-Ih & $18 \mathrm{r}-19 \mathrm{v}$ & \\
\hline $1624,12.3$. & Bílé Poličany & i.č. 2704, sign. XIII-Q2 & $20 r-21 v$ & \\
\hline $1624,18.3$. & Červené Poličany & i.č. 2731 , sign. XIV-Ph & $23 r-24 r$ & \\
\hline $1624,13.4$. & $\begin{array}{l}\text { Český Dub } \\
\text { (díl - Hodkovice) }\end{array}$ & i.č. 2727 , sign. XIV-Lh & $25 r-26 v$ & \\
\hline $1624,6.5$. & $\begin{array}{l}\text { Český Dub } \\
\text { (díl - } 7 \text { vsí) }\end{array}$ & i.č. 2737 , sign. XIV-Wh & $38 r-39 r$ & \\
\hline $1624,8.5$ & Fořt & i.č. 2729 , sign. XIV-Nh & $27 r-29 r$ & \\
\hline $1624,17.6$. & Boleslav, Poustka & & $30 r-31 r$ & \\
\hline $1624,18.6$. & Rohoznice & i.č. 2730 , sign. XIV-Oh & $32 \mathrm{r}-33 \mathrm{v}$ & \\
\hline $1624,4.7$ & Choteč & $\begin{array}{l}\text { i.č. 2732, sign. XIV-Qh } \\
\text { i.č. 2373, sign. I-O2 (op.) }\end{array}$ & $34 r-35 v$ & \\
\hline $1624,15.7$ & $\begin{array}{l}\text { Český Dub } \\
\text { (díl-Starý Dub) }\end{array}$ & i.č. 2708 , sign. XIII-U2h & $36 r-37 v$ & \\
\hline $1624,28.11$. & Bílé Poličany & i.č. 2721 , sign. XIV-Eh & $40 r-42 r$ & \\
\hline $1624,7.12$ & Hrubý Rohozec & i.č. 2735 , sign. XIV-Th & $43 r-45 r$ & \\
\hline $1625,4.7$. & Miletín & i.č. 2740 , sign. XIV-Zh & $46 r-47 v$ & \\
\hline $1625,10.7$ & Valečov & $\begin{array}{l}\text { i.č. } 2741 \text {, sign. XIV-A2h } \\
\text { i.č. } 2787 \text {, sign. XV-X }\end{array}$ & $48 r-49 v$ & \\
\hline $1625,6.8$ & Rašín & & $50 \mathrm{r}-52 \mathrm{r}$ & \\
\hline $1625,13.9$. & $\begin{array}{l}\text { Valtínov, Tlustec, } \\
\text { Hlemýźd' }\end{array}$ & i.č. 2739 , sign. XIV-Yh & $118 r-119 v$ & \\
\hline $1627,8.3$. & Návarov & & $60 r-62 r$ & \\
\hline $1627,22.3$. & $\begin{array}{l}\text { Stráž pod Ralskem, } \\
\text { Lemberk, Tulcpach }\end{array}$ & i.č. 2746 , sign. XIV-F2h & $63 r-65 r$ & \\
\hline $1627,30.3$. & Mladějov & & $87 \mathrm{r}-88 \mathrm{v}$ & $334 r-335 v$ \\
\hline $1627,6.6$. & Zásadka & & $53 r-54 v$ & \\
\hline
\end{tabular}




\begin{tabular}{|c|c|c|c|c|}
\hline $1628,5.1$. & Rudník & i.č. 2771 , sign. XV-F & $71 r-73 r$ & \\
\hline $1628,29.2$. & Bartoušov & i.č. 2777 , sign. XV-M & $81 r-83 r$ & \\
\hline $1628,6.3$ & Domaslavice & i.č. 2760, sign. XIV-U2h & $74 r-76 v$ & \\
\hline $1628,6.3$ & Chocnějovice & i.č. 2770 , sign. XV-E & $55 r-56 v$ & \\
\hline $1628,6.3$ & Chrastná & i.č. 2772 , sign. XV-G & $84 r-86 r$ & $157 \mathrm{r}-158 \mathrm{v}$ \\
\hline $1628,20.5$. & $\begin{array}{l}\text { Hrubý Rohozec, } \\
\text { Malá Skála }\end{array}$ & i.č. 2775 , sign. XV-K & $57 \mathrm{r}-59 \mathrm{v}$ & \\
\hline $1629,23.4$. & Kluky & i.č. 2784 , sign. XV-T & $104 \mathrm{v}-106 \mathrm{r}$ & $247 \mathrm{r}-250 \mathrm{v}$ \\
\hline $1629,15.6$ & $\begin{array}{l}\text { Holovousy, } \\
\text { Hradišt'ko }\end{array}$ & & $\begin{array}{l}106 \mathrm{v}- \\
108 \mathrm{v}\end{array}$ & $227 r-229 r$ \\
\hline $1629,15.6$. & Miletínek & i.č. 2781 , sign. XV-Q & $109 r-111 r$ & \\
\hline $1629,18.6$. & (Lázně) Bělohrad & i.č. 2782 , sign. XV-R & $112 r-114 r$ & \\
\hline $1629,9.8$ & Lemberk & i.č. 2783 , sign. XV-S & $115 \mathrm{r}-117 \mathrm{v}$ & \\
\hline $1630,20.3$. & Bílsko & i.č. 2785 , sign. XV-U & $127 \mathrm{r}-128 \mathrm{v}$ & $323 r-327 v$ \\
\hline $1630,5.4$ & Studenec & & $120 \mathrm{r}-122 \mathrm{r}$ & $309 r-310 v$ \\
\hline $1630,8.4$ & Sloupno & i.č. 2786 , sign. $X V-W$ & $124 \mathrm{v}-126 \mathrm{r}$ & $\begin{array}{l}271 \mathrm{r}-273 \mathrm{v}, \\
277 \mathrm{r}-278 \mathrm{v}\end{array}$ \\
\hline $1630,13.5$. & Lukavec & & & $261 r-268 v$ \\
\hline $1633,20.1$ & Lemberk & & $133 r-134 r$ & $\begin{array}{l}161 \mathrm{r}-162 \mathrm{r}, \\
171 \mathrm{r}-172 \mathrm{r}\end{array}$ \\
\hline $1633,20.1$. & Stráž pod Ralskem & & $131 \mathrm{r}-132 \mathrm{r}$ & $174 \mathrm{r}-175 \mathrm{v}$ \\
\hline $1633,20.1$. & Valečov & i.č. 2384, sign. I-Z2 (op.) & $135 \mathrm{r}-136 \mathrm{v}$ & $178 r-182 r$ \\
\hline $1633,22.3$. & Olešnice & & $137 \mathrm{r}-138 \mathrm{r}$ & \\
\hline
\end{tabular}

navíc, a sice prodej lenního statku Lukavec Karlovi Kryštofovi a Janovi Václavovi Stařimským z Libštejna 13. května $1630 .{ }^{75}$ Jak ukazuje dále připojená konvokační tabulka, dochovaly se tu v různé podobě především nejmladší kontrakty $\mathrm{z}$ třicátých let 17 . století.

Lze předpokládat, že archivní jednotliviny ke zkoumané problematice se mohou ukrývat i ve fondech souvisejících s osobami, které od Valdštejna lenní statky kupovaly. $\mathrm{Na}$ prvním místě se tu zřejmě nabízejí rodové (rodinné) archivy. Jejich lustrace by ale znamenala časově poměrně náročný proces s nejistým výsledkem. ${ }^{76}$ Nemluvě o tom, že zejména

dokumentu), 309r - 310v (koncept smlouvy na Studenec z roku 1630), 323r - 324v (kolacionovaný opis smlouvy na Bílsko z roku 1630, zhotovený v roce 1634), 326r - 327v (koncept téže smlouvy), 330r - 331v (koncept smlouvy na Třebňouševes z roku 1624), 334r - 335v (opis smlouvy na Mladějov z roku 1627). Vedle toho je opis smlouvy vztahující se ke statku Bartoušov ve VL, sign. F 67/26, kart. 40, fol. 7r - 9v.

75 Je dochován originál s Valdštejnovou pečetí a podpisy a pečetěmi Karla Kryštofa Stařimského jako kupujícího a dvou svědků. VL, sign. F 67/27, kart. 42, fol. 263r - 265v. Vedle toho jsou tu i dva koncepty. Tamtéž, $261 \mathrm{r}-261 \mathrm{v}, 268 \mathrm{r}-268 \mathrm{v} ; 262 \mathrm{r}-262 \mathrm{v}, 267 \mathrm{r}-267 \mathrm{v}$.

76 Tak např. prodej statků Hrubý Rohozec a Malá Skála Mikulášovi Des Foursovi je v př́slušném rodinném archivu dochován pouze ve formě dvou neověřených opisů. SOA Litoměřice, pobočka Děčín, fond Rodinný archiv Desfours-Walderode, Hrubý Rohozec, i.č. 798, sign. IIIa 12. 
opisy se mohou vyskytnout i v dalších fondech. ${ }^{77} \mathrm{~V}$ daném okamžiku bylo tedy na tuto badatelskou výzvu rezignováno a ke zpracování tématu byly využity pouze shora uvedené, nepochybně klíčové zdroje. Znovu je přitom třeba zdůraznit, že cílem této studie není vytvořit úplný přehled frýdlantských lén (která se do rukou svých držitelů, jak již bylo uvedeno, dostávala i jinými právními cestami než koupí), nýbrž prozkoumání souboru kupních smluv jakožto právních památek sui generis. K tomuto účelu lze dozajista vystačit se zdroji shora vyjmenovanými.

Ostatně porovnání s jinými přehledovými materiály umožňuje závěr, že asi o mnoho víc kupních smluv za dobu existence „terry felix“ ani uzavřeno nebylo. Například v rukopisu, který vznikl po polovině 17. století a v němž je mimo jiné sestaven i vcelku přehledný seznam lénem udělených statků (,Extract auß dem Friedländischen Contract Buch jenigen Gütter, so der Friedländer unter die Lehen verkaufft und abgetretten hat"'), se navíc objevují jen čtyři další položky, reprezentující prodej - Kurovodice Matyášovi z Wachtendunku (1624), Skaříšov Václavovi Mikulášovi Pecingarovi z Bydžína (1626) a Druzcov a Křenovy Kristiánovi z Valdštejna (1627). ${ }^{78}$ Jak ale vyplývá z připojených poznámek i dalších komplementárních materiálů, již v době sestavování tohoto přehledu nebyly smlouvy $\mathrm{k}$ těmto transakcím $\mathrm{k}$ dispozici a údaje se opíraly pouze o informace podané Janem Samuelem Lednickým z Dohlenštejna, buchhalterem české komory (konkrétně její české expedice), dřívějším buchhalterem komory frýdlantské. Tyto informace navíc nemusely být úplně přesné - alespoň podle připojených poznámek se v tzv. Extract-Buchu nacházel ohledně Druzcova přípis, že ,der Friedländer demselben nicht hat unterschreiben wollen“, a Křenovy údajně nebyly s odkazem na stejný zdroj Kristiánovi z Valdštejna prodány, ale pouze přenechány k užívání. ${ }^{79} \mathrm{I}$ to potvrzuje, že Rukopis B 16 doplněný o smlouvu lukaveckou skutečně představuje soubor víceméně úplný.

Na okraj budiž ještě dále podotknuto, že předkládaná studie se zaměřuje pouze na „nová“ frýdlantská léna a ponechává stranou „starolenni““ statky, jež byly součástí panství Frýdlant v užším slova smyslu. Důvodem je tu především odlišný právní režim, jemuž byly vystaveny. Ostatně v jejich případě byla také zachována kontinuita s dobou předbělohorskou a jejich prodej novým držitelům ze strany knížete byl tím pádem jevem spíše ojedinělým. ${ }^{80}$

Dochovaná písemná zachycení kupních kontraktů mají dvojí podobu. V drtivé většině se jedná o klasické smlouvy, tedy dvoustranná právní jednání, jejichž závaznost je potvrzena podpisy a pečetěmi obou smluvních stran. V závěrečných ustanoveních těchto listin se zprvu používalo pro jejich označení promiscue pojmů „Kauf“ 81 ,Brief“, 82 „Kaufs-

\footnotetext{
77 Např́iklad opis smlouvy o prodeji panství Návarov Gertrudě La Mottové je v DD 71, fol. 131r - 132v, ačkoliv jinak je celý kvatern věnován lenním listům.

78 VL, sign. F 67/26, kart. 39, kniha č. 18, fol. 17r (prodej Kurovodic za 18763 zlatých, 36 krejcarů a 4 denáry, 8. března 1624), 18r-18v (prodej Druzcova za 15691 zlatých, 3 krejcary a 2 denáry, 1627), 18v (nedatovaný prodej Křenov za 5000 zlatých) a 21v - 22r (přenechání/prodej Skaříšova v částce 3422 zlatých, 46 krejcarů 4 denáry, 23. října 1626).

79 VL, sign. F 67/26, kart. 39, kniha č. 18, fol. 18r - 18v.

80 Novou Ves prodal Albrecht v roce 1622 Jakubovi Reichardovi Heusterovi, díl Černous v roce 1627 Davidovi ze Schweinichen. První smlouva je dochována v opisu ve VL, sign. F 67/4, kart. 24, fol. 6r - 6v, 11r, druhá v HS-RACG, kart. 496, i.č. 1767, sign. XXII/28, nestr.

81 Např. při prodeji Červených Poličan Jiřímu Sadovskému ze Sloupna.

82 Např. při prodeji Nudvojovic Uršule Žofii hraběnce Šlikové.
} 
contract“63 či „Kaufbrief“, 84 resp. „Kaufsbrief“, 85 později převládlo prosté a neutrální „Urkund““ 86 Tak, jak je u smluv běžné, byly tyto dokumenty vyhotoveny ve dvou exempláŕích („welcher gedoppelt eines Lauts geschrieben“, popřípadě lakoničtěji ,gedoppelt geschrieben“). Každá strana si nepochybně ponechávala jeden z nich, což nepřímo potvrzuje i dochování dvou zpečetěných originálů smlouvy o prodeji Valečova Gerhardovi Taxisovi z Hulsu v roce 1625 ve valdštejnském rodinném archivu. Vysvětlení, proč se zde oba tyto exempláře sešly na jednom místě, je nutno spatřovat ve skutečnosti, že byl Gerhard v listopadu 1631 zatčen a uvězněn a statek mu byl zkonfiskován, ${ }^{87}$ přičemž jičínské úřrady při té příležitosti dozajista převzaly i prŕislušné písemnosti. V ostatních případech zůstaly druhé exempláře nepochybně v držení kupujících, respektive jejich právních nástupců, což je důvod, proč je možno jejich existenci předpokládat i ve fondech s Valdštejnem a Frýdlantskem apriorně nikterak nesouvisejících.

Pozoruhodný, a ne zcela jasný fenomén představují dochované originály smluv opatřené pečetí samotného Valdštejna, nikoli ovšem pečetěmi a podpisy kupující strany a svědků. Jeden se dochoval v Rodinném archivu Valdštejnů, ${ }^{88}$ dva další ve Valdštejnianech v Národním archivu. ${ }^{89}$ Nejpravděpodobněji lze mít za to, že jde o čistopisy, které připravila a pečetí opatřila dvorská kancelář frýdlantského vévodství v Jičíně, ale z nějakého důvodu nakonec nebyly použity. Jak již bylo uvedeno výše, genezi některých smluv lze sledovat prostřednictvím dochovaných konceptů, rovněž vzniklých na půdě dvorské kanceláře.

V rukopisu B 16 jsou čtyřri poslední kontrakty, uzavřené v roce 1633 , zachyceny ve velmi odlišné formě - mají podobu majestátů, potvrzujících podmínky uzavřené smlouvy a vydaných jednostranně vévodskou kanceláŕí a pod vévodskou pečetí (fol. 131r - 138r). To na první pohled evokuje hypotézu, že v mezidobí let 1630-1633, v nichž k prodeji lenních statků zřejmě nedocházelo, se změnila kancelářská praxe a smluvní konsenzus byl konfirmován ze strany zeměpána jako fakticky silnějšího kontrahenta, zatímco kupující ho demonstrovali převzetím statku, splácením kupní ceny ve smyslu smluvních ujednání a samozrrejmě také složením lenní přísahy.

Uvedená hypotéza ale ve světle dalších dochovných pramenů neobstojí. Za prvé, koncept jednostranného majestátu o prodeji se dochoval (a to dokonce hned ve dvou exempláŕích) již k prodeji statku Sloupno vévodovu bratranci Zdeňkovi z Valdštejna v dubnu $1630 .{ }^{90}$ Tento typ písemnosti má tedy poněkud starší kořeny a rozhodně nelze vyloučit, že došlo k jejímu vyhotovení i v souvislosti s dalšími převody ve zmíněném roce 1630, možná i při kontraktech starších. Za druhé, a to především, u dvou kontraktů z 20. ledna 1633 (vztahujících se ke statkům Stráž pod Ralskem a Valečov) je ve Valdštejnianech dochován i čistopis tradiční smlouvy, opatřený vévodskou pečetí, v koroboraci ovšem počítající i se

83 Např. při prodeji Hodkovic nad Mohelkou Kryštofovi Ecksteinovi z Erneggu.

84 Např. při prodeji Bílých Poličan Purkrartovi Kordulemu ze Sloupna.

85 Např. př̀ prodeji dílu českodubského panství Caesarovi Gillovi de Hungaria.

86 Např. při prodeji statku Fořt Janu Kristiánovi z Valdštejna.

87 K Taxisovu zatčení SVÁTEK, Dvorská kancelář Valdštejnova frýdlantského vévodství, s. 58. Jak ale ukazuje koncept lenního listu na valečovský statek z konce záríi 1631, ztratil zemský hejtman vévodovu důvěru ještě o něco dříve, než se doposud uvádělo.

88 RAV, Listiny, sign. XIV-Sh, i.č. 2734. Jde o prodej statku Roveň Pietrovi de Ferrara.

89 Jedná se o smlouvy datované 20. ledna 1633 a vztahující se ke statkům Stráž pod Ralskem a Valečov. VL, sign. F 67/27, kart. 42, fol. $174 \mathrm{r}-175 \mathrm{r}$ a $178 \mathrm{r}-179 \mathrm{r}$.

90 VL, sign. F $67 / 27$, kart. 42 , fol. $272 \mathrm{r}-273 \mathrm{v}, 277 \mathrm{r}-278 \mathrm{v}$. 
Tab. II. Chronologické rozložení kupních smluv podle let

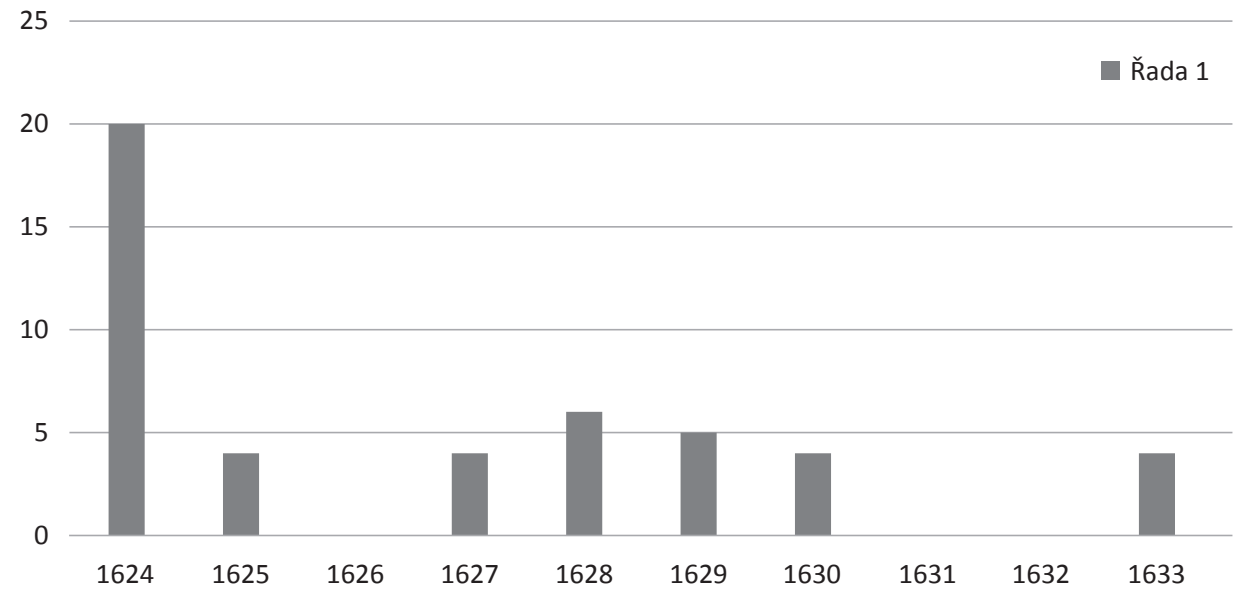

zpečetěním ze strany kupujícího a s podpisy obou smluvních stran (oproti předchozímu úzu se už ale nepočítá s potvrzením dvěma svědky). ${ }^{91}$ Správně je tedy třeba tento diplomatický posun interpretovat tak, že forma dvoustranné smlouvy se při prodeji lenních statků používala setrvale až do zániku frýdlantského quasistátečku. Ve třicátých letech 17. století začala být ale Valdštejnem z jičínské kanceláře (z ne zcela jasného důvodu) vydávána také zeměpanská konfirmace podmínek prodeje. Ta přitom rozhodně nebyla totožná s lenním listem, jenž byl kanceláŕí rovněž vydáván. Ostatně i v dochovaných kancelářských materiálech jsou tyto dokumenty označovány pojmem „Khauffcontract“, ačkoliv zřejmě přiléhavější by byl termín „Khauffbrieff“ (k tomu ovšem dlužno dodat, že tímto pojmem byly, jak již bylo zmíněno výše, označeny ve svém textu i některé „klasické“ smlouvy). Proto i tyto dokumenty, byt' nemají klasickou formu dvoustranného právního jednání, jsou dále považovány za kupní smlouvy v širším slova smyslu, tím spíše, že k Lemberku a Olešnici se ani dvoustranný instrument zrrejmě nedochoval. Ostatně jejich koroborace předpokládá, že navzdory jednostranné dikci a Valdštejnově samojediné intitulaci na začátku budou podepsány a zpečetěny jak jím, tak i př́íslušným kupujícím (,auch beyde Original durch Unß undt den Khauffer besiegeln undt unterschrieben laßen" $).{ }^{92}$

Za krátkou analýzu snad stojí také časové rozvrstvení zkoumaných smluv, zachycené ve výše uvedené tabulce. Je z něj patrné, že zcela výjimečný je rok 1624, kdy Valdštejn (zčásti ještě před formálním prohlášením Frýdlantska za knížectví!) vytvořil základy nové lenní soustavy prodejem ne méně než 20 lén (ve vztahu ke 47 celkově identifikovaným kontraktům jde o 42,6 \%). V dalších jednotlivých letech již počet uzavřených smluv nepřevyšuje 6, průměr za léta 1625-1633 činí přesně 3 smlouvy ročně. Rozvržení je nepravidelné, ve třech letech $(1626,1631,1632)$ nebyla zřejmě uzavřena žádná smlouva, v jiných naopak

\footnotetext{
91 VL, sign. F 67/27, kart. 42, fol. 174r - 175v, 178r - 179v.

92 Citace dle VL, sign. F 67/27, kart. 42, fol. 161r - 162r, 180r - 182r. S podpisem a pečetí kupujícího naopak nepočítá majestát o prodeji Sloupna v roce 1630.
} 
výsledné číslo uvedený průměr lehce převyšuje. S jistou dávkou opatrnosti lze tento další vývoj interpretovat tak, že rokem 1630 byla podoba frýdlantské lenní soustavy ve Valdštejnových očích víceméně dovršena. Čtyři prodeje z roku 1633 se totiž týkají poměrně rozsáhlých statků, které byly z nějakého důvodu uprázdněné a které se Valdštejn rozhodl dát novým držitelům. To, že si je neponechal jako součást komorních držav, ačkoliv k tomu měl ničím neomezenou př́iležitost, mimochodem jasně dokládá, že v hlavě nosil představu o ideálním poměru mezi zeměpanskými a lenními statky a té se snažil v rámci možností držet.

\section{Kupní smlouvy k lenním statkům - obsahová analýza}

\section{1 Úvod smlouvy - datace, označení, smluvní strany}

Text klasických smluv je otevírán datací v obvyklé, v 17. století již nejrozšířenější podobě, sestávající z číselného označení dne, názvu měsíce a čísla roku. Číslovky jsou přitom zásadně rozepisovány slovně. Následuje typové označení kontraktu (,ein beständiger und wohlbedachtiger Erblehenskauf") a vymezení smluvních stran. Jen v několika výjimečných prŕípadech je pořadí těchto údajů přehozeno, přičemž se očividně jedná o odchylku nahodilou, která nemá z hlediska obsahu smlouvy naprosto žádný význam. ${ }^{93}$

Jako první z kontrahendů je v těchto smlouvách vždy uváděn Valdštejn coby prodávající, a to s titulaturou měnící se v návaznosti na průběh jeho pozoruhodné kariéry. ${ }^{94} \mathrm{Ve}$ smlouvách se postupně objevuje hned devět jejích variant:

V kontraktech uzavřených roku 1624 vystupuje prodávající vždy jako vladař valdštejnského a frýdlantského domu, kníže frýdlantský, císařský válečný rada, komorník, plukovník v Praze a generál polní strážmistr (,,Regierer des Hauses Waldstein und Friedland, Fürst zu Friedland, Römisch Kaiserlichen Majestät Kriegsrat, Cammerer, Obrist zu Prag und General Feldwachtmeister"). Tato titulatura kumuluje Valdštejnovo zařazení ve feudální hierarchii s hodnostmi dvorskými i vojenskými. Jako vladař valdštejnského a frýdlantského domu je Albrecht poprvé titulován v majestátu z 15. září 1622, ${ }^{95}$ do knížecího stavu ho spolu s mužskými potomky v primogeniturní linii císař povýšil 7. září $1623 .{ }^{96}$ Komorníkem tehdy ještě arciknížete Ferdinanda Štýrského, pozdějšího císaře a krále Ferdinanda II.,

93 Tuto strukturu má smlouva o prodeji Studence (5. 4. 1630). Při prodeji Valtínova, Tlustce a Hlemýždího (13. 9. 1625) kancelář uvedla, že se souhlasem a na povolení Valdštejna je mezi ním a kupujícími (kupujícími) uzavírána kupní smlouva. Podobně je strukturována listina o prodeji Bílska (20. 3. 1630), v níž se vedle souhlasu („Consens“) a povolení („Bewilligung“) mluví navíc o nařízení („Befehl“). V př́ípadě Sloupna (8. 4. 1630) pak byl vypuštěn souhlas a zůstalo jen „Befelch (sic!) und Bewilligung“.

94 Vývoj Valdštejnovy titulatury lze snad na první pohled vnímat jako záležitost ryze formální, avšak není sporu, že z ní lze vyvozovat i některé konsekvence právní. Prozatím ale tato problematika zůstala ve zkoumání Valdštejnových osudů překvapivě upozaděna. Zevrubná analýza ovšem nebude moci pro futuro vycházet pouze ze smluv, ale bude samozrejmě muset pracovat též s písemnostmi jednostrannými, především těmi zásadními a slavnostně koncipovanými. Podobně je široce otevřené pole i pro výzkum sfragistický, byt zde se lze opírat alespoň o základní přehled 15 typů Valdštejnových pečetí, který sestavil SVÁTEK, Dvorská kancelář Valdštejnova Frýdlantského vévodství, s. 84-85.

95 RAV, Listiny, sign. N-6, i.č. 19.

96 RAV, Listiny, sign. N-9, i.č. 23. Podle rukopisu B 16 by se mohla zdát mezi listinami z roku 1624 výjimečnou, pokud jde o titulaturu, kupní smlouva týkající se prodeje 7 vsí od českodubského panství Jakubovi Reichardovi Heusterovi, v níž se neobjevuje titul frýdlantského knížete („Regierer des Hauses Waldstein und Friedland, Römisch Kaiserlichen Majestät Kriegsrat, Cammerer, Obrist zu Prag und General Feld- 
se stal zřejmě již v roce 1615, titul dvorského válečného rady nesl od srpna 1620. Pokud jde o zařazení vojenské, pražským plukovníkem (což byl zcela specifický post vytvořený právě pro něj) byl jmenován 18. ledna 1622 a vytoužené generálské hodnosti se dočkal v červnu 1623, několik dní před svým sňatkem s Isabelou Kateřinou z Harrachu. ${ }^{97}$

13. června 1625 povýšil Ferdinand II. frýdlantského knížete na vévodu, ${ }^{98}$ takže ve dvou smlouvách uzavřených v červenci téhož roku již vystupuje coby vévoda frýdlantský, císařský válečný rada, komorník a plukovník v Praze („Herzog zu Friedland, Römisch Kayserlichen Majestät Kriegsrat, Cammerer und Obrist zu Prag“). Definitivně opuštěna byla překonaná hodnost rodového vladaře, zároveň se také ztrácí vojenská hodnost generála polního strážmistra, opuštěná zřejmě s přihlédnutím $\mathrm{k}$ tomu, že bylo Valdštejnovi během roku 1625 svěřeno vrchní velení nad celou císařskou armádou. Při prodeji dvoru Rašín v srpnu téhož roku je pak prodávající v návaznosti na to specifikován jako vévoda frýdlantský, císařský válečný rada, komorník a plukovník v Praze a generál císařské armády („Herzog zu Friedland, Römisch Kayserlichen Majestät Kriegsrat, Cammerer und Obrist zu Prag und General über die Kaiserlichen Armee“). Prakticky totožná je titulatura použitá opakovaně v roce 1627, pouze nejvyšší velení nad habsburskou císařskou armádou je pro změnu obsaženo v hodnosti generalissima („Herzog zu Friedland, Römisch Kayserlichen Majestät Kriegsrat, Cammerer, Obrist zu Prag und General obrist Feldhauptmann“). Posledně jmenované označení se přitom objevuje již při prodeji Valtínova, Tlustce a Hlemýždího v září 1625, kdy ale došlo k určitému excesu z dosud vcelku plynulého a logického vývoje - Valdštejn byl ve smlouvě označen pouze jako vévoda frýdlantský a generalissimus nad císařskou armádou (,Herzog zu Friedland, Römisch Kayserlichen Majestät über dero Armee General obrist Feldhauptmann“).

V roce 1627 byla mezi císařem a Valdštejnem zahájena jednání o kompenzaci alespoň části generalissimových pohledávek postoupením dolnoslezského Zaháňského knížectví, od hranic Frýdlantska nepř́liš vzdáleného. Problém byl ovšem v tom, že ve skutečnosti byla tato nevelká země, oceněná slezskou komorou na 150850 rýnských zlatých a 1 peníz, zatížena obrovskými dluhy. ${ }^{99}$ Nakonec se ale našlo vpravdě šalamounské řešení - Zahán̆sko, k němuž bylo připojeno též panství Priebus, bylo v záŕí 1627 za uvedenou sumu Valdštejnovi skutečně prodáno, ale očištěné od dluhů, jež (spíše formálně) převzal sám císař. ${ }^{100}$ Protože ale Valdštejn trval na tom, aby i Zaháňsko stejně jako Frýdlantsko držel coby léno,

wachtmeister“). V originále smlouvy, uloženém v RAV, Valdštejniána, i.č. 2737, sign. XIV-Wh, ale obsažen je, takže se tu jedná pouze o chybu vzniklou nepozorným přepisem textu.

97 K Valdštejnovu vzestupu ve dvorské a vojenské hierarchii např. JANÁČEK, Valdštejn a jeho doba, s. 117 , $192,235,273$.

98 Originál tohoto diplomu není dochován a jeho doslovný text není znám ani odjinud. Zmínka o něm se činí v majestátu o povýšení Frýdlantska na vévodství v lednu 1627.

99 FÖRSTER, Wallenstein, Herzog zu Mecklenburg, Friedland und Sagan, als Feldherr und Landesfürst in seinem öffentlichen und Privat-Leben, s. 71-72; HEINRICH, Wallenstein als Herzog von Sagan, s. 1-2.

100 Listina z 1. záŕí 1627 se bohužel nedochovala. Podmínky prodeje jsou známy z listu císaře Ferdinanda slezské komoře, vydaného o dva dny později. FÖRSTER, Wallenstein, Herzog zu Mecklenburg, Friedland und Sagan, als Feldherr und Landesfürst in seinem öffentlichen und Privat-Leben, s. 73. List cituje také KNOZ, T. Pobělohorské konfiskace. Moravský průběh, středoevropské souvislosti, obecné aspekty (= Knižnice Matice moravské, svazek 19). Brno: Matice moravská, 2006, s. 441 (pokud na s. 431 zároveň uvádí, že panství Zahán̆, Naumburg a Priebus byla Valdštejnovi přiznána již v roce 1621, jde nepochybně o překlep $\mathrm{v}$ dataci). 
byla původní smlouva stornována a 2. ledna 1628 vydal císař na Zaháňsko lenní list. ${ }^{101}$ Dalším majestátem z 15. února 1628 povýšil Ferdinand II. Zaháňsko formálně na vévodství102 Stejného dne také v Praze Valdštejnovi Zaháňsko slavnostně předal ${ }^{103}$ a Valdštejn mu za ně osobně složil lenní př́isahu. ${ }^{104}$

V kontextu Valdštejnova stále ještě pokračujícího vzestupu zároveň ztratily na významu dvorské hodnosti komorníka a válečného rady a bylo celkem logické, že byly upozaděny a z generalissimovy titulatury po roce 1627 zcela vypadly. Naproti tomu, v návaznosti na velmi ambiciózní maritimní plány, které vévoda ve Vídni předložil, se mu majestátem z 21. dubna 1628 dostalo nového titulu, ${ }^{105}$ a smlouvy z roku 1628 a počátku roku 1629 ho tak zachycují coby vévodu frýdlantského a zaháňského, císařského generalissima a též generála Oceánického a Baltického moře („Herzog zu Friedland und Sagan, Römisch Kayserlichen Majestät General obrist Feldhauptmann, wie auch des Oceanischen und Baltischen Meers General").

Titulárně se vrcholem Albrechtova strmého vzestupu stalo udělení vévodství meklenburského, k němuž došlo 16. června 1629.106 Jako meklenburský vévoda se totiž stal bezprostředním říšským knížetem s právem zasedat v kurii knížat na říšském sněmu, což byla výsada, kterou s sebou vévodský titul spojený s Frýdlantskem a Zaháňskem jako součástmi České koruny nenesl. Stejně tak neznamenalo otevřené dveře na říšský sněm ani samotné udělení hodnosti ř́šškého knížete v roce 1623. Teprve se ziskem meklenburského vévodství se tak Valdštejn definitivně vymanil z predestinace kariérního vzestupu limitovaného hranicemi českého státu.

Právo užívat titulu vévody meklenburského bylo Valdštejnovi ve skutečnosti formálně propůjčeno již 26. ledna 1628, kdy mu dal císař dvěma listinami do zástavy (de iure ale vlastně do podzástavy ${ }^{107}$ ) jednak vévodství Meklenburk, knížectví Venden a hrabství Schwerin se zemí Rostock a Stargard (to vše v částce 700000 zlatých), jednak biskupství zvěřinské a další duchovní statky v Meklenbursku (tyto v částce dalších 750000 zlatých). ${ }^{108}$ Kupodivu se ovšem zdá - a minimálně dochované kupní smlouvy to potvrzují -, že zpočát-

101 Opisy lenního listu jsou v RAV, Valdštejniána, i.č. 2366, sign. I-F2 a v RAV, Rukopisy, i.č. 262, nestr. (př́loha č. 9).

102 Originál majestátu je v RAV, Listiny, sign. N-26, i.č. 41.

103 Srovnej dopis Heřmana z Questenberka, jehož výtah otiskl STRAKA, C. Albrecht z Valdštejna a jeho doba na základě korrespondence opata strahovského Kašpara z Questenberka. Edice Rozpravy České akademie císaře Františka Josefa pro vědy, slovesnost a umění, třída I., číslo 44. Praha: Nákladem České akademie císaře Františka Josefa pro vědy, slovesnost a umění, 1911, s. 16 („Dnes císař vévodu Friedlandského slavnostním způsobem veřejně uvedl v držení vévodství Zaháňského ve Slezsku“").

104 ČDK, sign. II A 4, kart. 295, i.č. 638.

105 Opis listiny je v RAV, Valdštejniána, i.č. 2352, sign. I-R.

106 RAV, Listiny, sign. N-34, i.č. 47. Lenní přísahu složili Albrechtovým jménem ve Vídni Maxmilián z Valdštejna a Jindřich ze Saint Julienu. FÖRSTER, Wallenstein, Herzog zu Mecklenburg, Friedland und Sagan, als Feldherr und Landesfürst in seinem öffentlichen und Privat-Leben, s. 99.

107 V pozici zástavního držitele byl v této fázi sám císař, který se Meklenburska ujal s poukazem na škody, které mu v tzv. dánské válce vznikly v souvislosti se zapojením meklenburských vévodů Adolfa Bedřicha a Jana Albrechta do nepřátelských akcí proti němu.

108 RAV, Listiny, sign. N-24, i.č. 39; Valdštejniána, i.č. 2367, sign. I-H2. Charakter Valdštejnovy držby bystře vystihl i Heřman z Questenberka, který svému bratrovi, strahovskému opatovi, 15. února 1628 napsal, že vedle udělení Zaháňska císař Valdštejnovi ,pojistil ... ještě výlohy, učiněné na vojsko, císařskou listinou, kterouž rozlehlé vévodství Meklenburské přisuzuje se mu za hypotéku“. STRAKA, Albrecht z Valdštejna a jeho doba na základě korrespondence opata strahovského Kašpara z Questenberka, s. 16-17. 
ku generalissimus z nějakého důvodu této možnosti nevyužíval, nebot' v roce 1628 a ještě při prodeji zboží Kluky v dubnu 1629 jako meklenburský vévoda nevystupuje. Změna v tomto směru nastává teprve ve smlouvách z června 1629, v nichž se tituluje jako vévoda meklenburský, frýdlantský a zaháňský, císařský generalissimus a generál Oceánického a Baltického moře („Herzog zu Mechelburg, Friedland und Sagan, Römisch Kayserlichen Majestät General obrist Feldhauptmann, wie auch des Oceanischen und Baltischen Meers General“). Zřejmě se tak stalo až ve chvíli, kdy už bylo domluveno, že Meklenbursko bude Valdštejnovi formálně uděleno lénem - to se sice stalo až následujícího dne potom, co Albrecht prodal s novou titulaturou Holovousy a Hradišt'ko, resp. Miletínek. Ovšem již předtím, 9. června, vyhlásil Ferdinand II. zvláštním manifestem, že ozbrojeným odporem proti němu propadli dosavadní meklenburští vládci, vévodové Adolf Bedřich a Jan Albrecht, ř́išské klatbě, ale že od ní milostivě upouští a ,pouze“ propůjčuje jejich země Valdštejnovi. 109

Význam, který Valdštejn Meklenbursku přisuzoval, je nejlépe patrný z toho, že hodnost meklenburského vévody byla $v$ jeho titulatuře předřazena dokonce $i$ důstojenství vévody frýdlantského (ačkoliv Frýdlantsko tvořilo základnu Valdštejnovy moci a bylo jeho srdci nepochybně nejbližší) a že ji záhy začaly doprovázet i odkazy na jednotlivé součásti tohoto nově uděleného panství - tak ve smlouvě ze srpna 1629 a pak i dalších z roku 1630 vystupuje coby vévoda meklenburský, frýdlantský a zaháňský, kníže vendenský, hrabě zvěřinský, pán zemí Rostok a Stargard, císařský generalissimus a generál Oceánického a Baltického moře (,Herzog zu Mechelburg, Friedland und Sagan, Fürst zu Wenden, Graf zu Schwerin, der Lande Rostock und Stargard Herr, Römisch Kayserlichen Majestät General obrist Feldhauptmann, wie auch des Oceanischen und Baltischen Meers General“).

Jak je známo, měla Valdštejnova vláda v Meklenbursku (během níž byla provedena poměrně zásadní správní reforma) jen epizodický charakter a původní zeměpáni se pod záštitou švédského krále záhy svých severoněmeckých držav opět zmocnili. ${ }^{110}$ Souviselo to i s tím, že Valdštejnovi bylo na nátlak bavorského kurfiřta a dalších řŕšských knížat odebráno vrchní velení nad císařskými vojsky, což ho zbavilo možnosti zajistit jejich účinnou obranu. Poté, co mu císař z nezbytí svěřil následujícího roku tzv. druhý generalát, kompenzoval mu faktickou ztrátu Meklenburska postoupením dolnoslezského knížectví (velko)hlohovského, sousedícího se Zaháňskem. Jako dědičné léno je svému vojevůdci udělil 14. srpna $1632 .{ }^{111} \mathrm{~V}$ poslední fázi svého pohnutého života a vlády tak Valdštejn vystupoval jako vévoda meklenburský, frýdlantský, zaháňský a velkohlohovský, kníže vendenský, hrabě zvěřinský, pán zemí Rostok a Stargard („Herzog zu Mechelburg, Friedland, Sagan und Gross Glogau, Fürst zu Wenden, Graf zu Schwerin, der Lande

109 POLIŠENSKÝ - KOLLMANN, Valdštejn. Ani císař, ani král, s. 126.

110 Dodnes významné studie k Valdštejnově vládě v Meklenbursku publikoval na stránkách periodické řady Jahrbücher des Vereins für meklenburgische Geschichte und Alterthumskunde její uspořadatel, meklenburský velkovévodský tajný archivní rada Dr. Georg Christian Friedrich Lisch - srovnej především LISCH, Wallensteins Abzug aus Meklenburg im Jahre 1629, s. 45-79; TÝŽ, Ueber Wallensteins Regierungsform in Meklenburg, s. 3-48; TÝŽ, Wallensteins letzte Kammer und Hof-Verordnung bei seinem Abzuge aus Meklenburg für den Kammer-Regenten Heinrich Kustosz. JVMGA, 1871, XXXVI, s. 49-54; TÝŽ, Wallensteins Kirchen- und Schul- Regierung in Meklenburg. JVMGA, 1872, XXXVII, s. 3-41. Dále viz např. HUNZIKER, Wallenstein als Landesherr insbesondere als Herzog von Meklenburg; GROTEFEND, Meklenburg unter Wallenstein und die Wiedereroberung des Landes durch die Herzöge, s. 227-284. 
Rostock und Stargard Herr"). Zcela přitom již opustil jakékoliv odkazy na své funkční zařazení v císařské armádě, jejíž vrchní velení mu bylo (za ne zcela přesně známých podmínek, avšak nepochybně s kompetencemi neobvykle širokými) svěřeno v dubnu 1632 tzv. göllersdorfskou smlouvou. ${ }^{112}$

Pokud jde o kupující, bezmála v polovině smluv jsou specifikováni pouze jménem, př́ípadně prŕíjmením a predikátem, zpravidla ovšem nikoli domicilem. Takto stroze jsou vesměs označeni i Valdštejnovi př́ibuzní, pouze Zdeněk z Valdštejna je v kupní smlouvě na statek Sloupno označen jako strýc (,Vetter“) Jeho knížecí Milosti. Stejně tak nejsou v kupních smlouvách kupodivu často reflektovány ani funkce, které kupující zastávali ve správním aparátu frýdlantského vévodství. Výjimkou jsou úřady nejvyšší - když kupoval Gerhard Taxis v roce 1625 valečovské léno, byl ve smlouvě označen nejen jako podplukovník, ale také nařízený zemský hejtman (,hochgedachter ihrer fürstl. Gnaden Herzogens zu Fridland wohl verordneten Landeshauptmann“), Jeroným Bukovský z Neudorfu byl při koupi dvora Rašín a dvou vesnic v témže roce titulován jako komorní prezident (,ihrer fürstl. Gnaden Cammer Praesidenten“), což je jiné, málo obvyklé označení jeho úřadu regenta. Reflektován byl $\mathrm{v}$ př́slušné listině též post kancelářského rady (dr. Adam Neff) a někdy též hodnosti dvorské. Tak Kryštof Pavel hrabě z Lichtenštejna byl při koupi vartenberského zboží zachycen jako vévodův hofmistr, ovšem s tím, že tento titul přišel hierarchicky až za titulem císařského rady a komorníka a vojenskou hodností plukovníka. Zakotvení ve dvorském prostředí bylo významnou devizou i u manželů Coranazzaniových, kupujících v roce 1628 Domaslavice - manžel Pavel je ve smlouvě označen jako Valdštejnův komorník, manželka Anna Zuzana jako hofmistryně vévodkyně Isabely Kateřiny.

Někdy byli Valdštejnovi podřízení označeni prostým, nic bližšího nesdělujícím obratem „lieber Getreuer“, což se mimo jiné poštěstilo i shora jmenovanému Albrechtovu bratranci Zdeňkovi z Valdštejna. Pouze u dr. Adama Neffa došlo k jakémusi zdvojení, když byl označen za milého služebníka a následně byla upřesněna i jeho funkce rady dvorské kanceláře, přičemž zdůrazněna byla i skutečnost, že je doktorem obojího práva (,lieben Getreuen ... beider Rechten Doctori und ihrer fürstl. Gnaden Hofcanzelei Rath“). V řadě př́padů ale prokazatelná držba zemského (a to nejen nižšího, ale i ústředního) či dvorského úřadu do kupní smlouvy zachycena nebyla.

Pravidelně byla naproti tomu uváděna vojenská hodnost důstojníků, tvořících, jak již bylo svrchu uvedeno, významnou a početně silnou skupinu Valdštejnových vazalů. U nižších šarží se zejména zpočátku, kdy ještě Valdštejn nedosáhl postu generalissima, zdůrazňovala i skutečnost, že byli služebně zařazeni př́mo do Valdštejnova regimentu (např. Pietro de Ferrara: ,über die Cavagleria des fürstl. Waldsteinischen Regiments bestelter obrist Wachtmeister“, Jakub Reichard Heuster: ,,bestellten Hauptmann unter ihr fürstl. Gn. hochlöblichen Regiment“, Augustin Morando: „,unter dem fürstl. Waldsteinischen Regiment bestellter Hauptmann“ aj.). Také při prodeji statků Návarov Gertrudě La Mottové a Bartoušov Kateřině Noue Guterdingové (formálně jednající na místě nezletilého syna) bylo zdůrazněno, že jde o vdovy po již zesnulých císařských důstojnících.

112 Originál této smlouvy se nedochoval, k jejímu předpokládanému obsahu srovnej zejména starší práce GINDELY, A. Waldsteins Vertrag mit dem Kaiser bei der Übernahme des zweiten Generalats. Prag: Druck von Dr. E. Grégr, 1889; KOLLMANN, H. Některé příspěvky k smlouvě göllersdorfské uzavřené v př́íčině druhého generalátu Valdštejnova. Český časopis historický, 1895, I, s. 347-371. 
Konečně se u kupujících eventuálně objevuje zmínka o jejich hodnosti dvorské, a to přímo na dvoře panovnickém, popřípadě při dvorech dalších př́íslušníkủ habsburské dynastie. Jak již bylo naznačeno výše, v souvislosti s Kryštofem Pavlem z Lichtenštejna, dvorské úřady spojené s Habsburky měly v titulatuře vždy absolutní přednost. V dochovaném souboru leníků, kteří své statky od Valdštejna koupili, je takto doložen jeden císařský rada a komorník (zmíněný hrabě Lichtenštejn), jeden císařský komorník, který zastával tentýž úřad u dvora arciknížete Leopolda (Mikuláš Des Fours), jeden truksas (Gerhard Taxis) a jeden služebník (Jan Jezbera z Kolivé Hory ${ }^{113}$ ).

Většinou vystupuje jako kupující jedna osoba, nejčastěji muž - šlechtic. Léna byla ale v několika prŕípadech prodána i ženám, u nichž jediné omezení spočívalo v tom, že vzhledem ke své omezené právní způsobilosti musely jmenovat plnomocníka, který jejich jménem složil Valdštejnovi (respektive jeho zástupcům ve dvorské kanceláři) lenní př́ísahu. Jen v př́ípadě „složeného“ lenního statku Valtínov - Tlustec - Hlemýždí vystupuje v roli společných a nedílných kupujících pět Valdštejnových důstojníků, přičemž bylo zřejmě na nich, jakým způsobem se o čerstvě nabyté majetky porovnají (ostatně poměrně záhy se držba tohoto statku koncentrovala v rukou jediného z nich). Statek Domaslavice byl prodán společně manželskému páru Pavlovi a Anně Zuzaně Cornazzaniovým a téhož dne (6. března 1628) je datována i nejednoznačná smlouva vážící se ke statku Chrastná. V jejím úvodu je jako kupující uveden pouze Volf Ladislav ze Šlejnic, v dalším textu se nicméně uvádí, že Valdštejn ze své milosti slevil z kupní ceny 10000 zlatých jemu a jeho nevěstě Ludmile Sedlecké z Drchlavy, kterou si namluvil ve fraucimoru vévodkyně Isabely Kateřiny. Vzhledem k tomu, že po smrti jednoho z manželů měl statek držet přeživší, figurovala i Ludmila v tomto případě prakticky jako spolukupující. Konečně ve dvou př́ipadech došlo k uzavření smlouvy v zastoupení - tak Kateřina Nouenová koupila statek Bartoušov ve jménu a k ruce svého nezletilého syna (,,im Namen und zu Handen Anastasii Noue Guterdings ... eheleiblichen, jetzo aber münderjährigen Sohnes“) a podobně Václav starší Záruba z Hustířan Studenec na místě a k ruce (,anstatt und zu Handen“) dcery Johany Uršuly. Konečně Karel Kryštof Stařimský z Libštejna koupil Lukavec pro sebe a zároveň i svého nezletilého mladšího bratra (,für sich selbst so wohl anstadt und zuhanden seines minderjärigen Bruders Johan Wiencko“).

\subsection{Předmět smlouvy}

Další text smlouvy je uvozen obratem vyjadřujícím vůli zeměpána prodat kupujícímu příslušný statek, což Valdštejn činil explicitně jako řádný dědičný a lenní pán frýdlantského státečku (,,als ordentlicher Erb- und Lehensherr des Fürstenthumbs, resp. později Herzogthumbs Fri(e)dland“). Na první pohled samozřejmá a nekontroverzní formulace otevírá ale ve skutečnosti velmi zajímavý interpretační prostor. A to z jednoho prostého důvodu. Tato pasáž se objevuje ve všech dochovaných kupních smlouvách, počínaje těmi nejstaršími z ledna 1624. Jak ale bylo konstatováno výše, Ferdinand II. Frýdlantsko na knížectví formálně povýšil teprve 12. března uvedeného roku. Jak je tedy možné, že se Valdštejn v listinách výslovně prezentuje jako pán státoprávního celku, který de iure neexistoval?

113 V roce 1630 (2. listopadu) byl povýšen do rytířského stavu a obdržel nové jméno Jezberovský z Olivé Hory. SAL, kniha č. 32a, i.č. 14, fol. 596r - 599r. 
Nabízela by se hypotéza, že fyzicky byly smlouvy datované před tímto dnem vyhotoveny až po něm a reflektují tedy status platný v okamžiku vydání. Popř́ípadě, že v době vydání již bylo propůjčení statutu knížectví pevně domluveno a Valdštejnova kancelář na tuto budoucí změnu s předstihem reagovala. Skutečnost, že ne každý dokument musí pocházet z doby, k níž se svou datací hlásí, ostatně velmi přesvědčivě dokumentuje kupní smlouva uzavřená s Jakubem Reichardem Heusterem na část panství Český Dub, hlásící se k 6. květnu 1624. Její originál je totiž opatřen Valdštejnovou pečetí s opisem ALBRECHT HERTZOG ZV FRIDLAND, navíc v jejím textu se stejně tak anachronicky uvádí, že Valdštejn př́ślušný majetek prodal jako pán frýdlantského vévodství. ${ }^{114}$

Je nicméně nutno upozornit, že ve zkoumaném listinném materiálu dochází celkově ke změně označení Frýdlantska (namísto knížectví vévodství) již v létě roku 1625 a počínaje listinou miletínskou ze 4. července uvedeného roku je označení „Herzogthum“ používáno stabilně a bez jakýchkoliv odchylek. Přitom k povýšení Frýdlantského knížectví na vévodství došlo ze strany císaře jakožto českého krále opět až podstatně později, na počátku roku 1627. A tak se spíše zdá, že vzápětí po povýšení na knížete začal Valdštejn se sebevědomím sobě vlastním označovat svoji doménu jako knížectví a stejně tak mu analogicky přiznání titulu vévody stačilo k tomu, aby se svou majetkovou základnou spojil i tento vyšší status. Následná císařská privilegia pak již pouze konvalidovala tento jeho postup - podobně jako privilegia razit mince se Albrechtovi dostalo až 16. února 1628, ačkoliv reálně byla ražba v nově zř́izené jičínské mincovně zahájena již v létě 1626.115

Nezbytnou náležitostí kupní smlouvy bylo samozřejmě vymezení předmětu prodeje. Jednotlivá léna byla většinou primárně vymezována prostřednictvím prŕíslušného panského sídla, resp. správního centra. Jím byl bud’ zámek (,Schloß“), ${ }^{116}$ tvrz („Rittersitz“), případně jen poplužní dvůr („Mayerhoff“, v některých listinách též „Forberg“). Poněkud nejasná je v tomto situace ohledně léna Roveň, když kupní smlouva centrální objekt popisuje jako dvůr („Hof Roven genandt“) s ovčínem a poplužním dvorem (,sambt einer Schäfferey und Mayrhof"). Nezdá se ale, že by zde mělo jít o nějaký kvalitativně specifický objekt, ale spíše to byl tradiční poplužní dvůr, který byl ve smlouvě nedopatřením zachycen tímto duplicitním a poněkud matoucím způsobem. K tomu je potřeba doplnit, že některá léna (zde jde především o oddělené části českodubského dominia) podobným rezidenčním objektem vůbec nedisponovala.

Dlužno podotknout, že spíše výjimečně, než pravidelně, bylo ve smlouvách užíváno pojmu zboží (,Gut“), jímž jsou jinak šlechtické državy v dobových pramenech běžně nazývány. Někdy byl tento termín jen mechanicky připojen k jádru državy - tak se objevují spojení zboží a rytiřské sídlo („Gut und Rittersitz“) či zboží a zámek („Gut und Schloss“), dokonce také zboží, sídlo a ves („Gut, Rittersitz und Dorf“), při prodeji léna Fořt byly pojmy zboží a sídlo dokonce avizovány jako synonyma („Gut oder Sitz“). Když kupovala Engelburka Zárubová Bílé Poličany, byl pojem zboží zařazen až za sídlo, a dokonce i k němu př́islušející poplužní dvůr (,Sitz und Mayerhoff, auch das Gut“).

114 RAV, Valdštejniána, i.č. 2737, sign. XIV-Wh.

115 Podrobněji k Valdštejnovu mincovnictví zejména MEYER, Albrecht von Wallenstein (Waldstein) Herzog von Friedland und seine Münzen, passim; NOHEJLOVÁ, Mincovnictví Albrechta z Valdštejna, s. 28-73.

116 Jako zámek byly označovány i původně gotické stavby, které si navzdory pozdějším úpravám zachovaly povahu hradu, např́klad Valečov. 
Určitou nahodilost $\mathrm{v}$ přístupu autorů smluv, nepochybně úředníků jičínské dvorské kanceláře, lze demonstrovat též na smlouvách vztahujících se ke statku Návarov - v roce 1624 byl Kristiánovi z Valdštejna prodán prostě „das Schloss Nawarow“ s 10 vesnicemi, v roce 1627 , kdy panství koupila Gertruda La Mottová a kdy k zámku bylo připojeno dokonce 18 vesnic, hovoří smlouva pouze o dílu panství Návarov (,einen Theil der Herrschaft Nawarow“). Což je o to zajímavější ve světle skutečnosti, že návarovský statek byl během 16. století připojen k sousednímu dominiu Hrubá Skála. Zcela případně byla naproti tomu jako díl panství Český Dub označena jednotlivá drobnější léna, která od něj byla odprodána v průběhu roku 1624, ${ }^{117}$ a také u dvora Nudvojovice se třemi vesnicemi, které téhož roku koupila hraběnka Šliková, bylo zdůrazněno, že jde o část panství Svijany. Z lenních statků jako takových byly termínem panství („Herrschaft“) označeny pouze Stráž pod Ralskem (Vartenberk), Lemberk a Valečov, ${ }^{118}$ i když jejich rozsah nebyl větší než v př́ipadě některých jiných statků (například ke Stráži patřilo kromě městečka jen 6 vesnic). Jak patrno, užívání pojmů zboží („Gut“) a panství („Herrschaft“) se neřídilo žádnou zjevnou a konzistentní logikou, ale mělo spíše intuitivní charakter. Označení panství se tak v prŕíslušných smlouvách nedočkaly ani některé stabilní územně-správní celky s dlouhou předbělohorskou historií.

Vedle panských sídel a poplužních dvorů, jež je možno bez nadsázky označit za základní stavební kameny feudálních panství, jsou vždy jmenovitě uváděny i městečka a vesnice, které byly jejich další klíčovou součástí - výjimku představuje pouze jedna ze smluv týkající se statku Hrubý Rohozec, v níž je uveden pouze počet vesnic (konkrétně 29). Nutno jedním dechem dodat, že městečka byla součástí frýdlantských lén spíše ojediněle konkrétně se do rukou Valdštejnových vazalů takto dostaly Hodkovice nad Mohelkou, Kněžmost, Miletín, Stráž pod Ralskem (Vartenberk) a Železný Brod.

Pokud jde o vesnice, ty byly v některých, vcelku ovšem málo četných př́ipadech v důsledku složitějšího majetkoprávního vývoje rozděleny mezi několik vrchností a prodávána pak byla jen př́íslušná část. Ta nebývala konkrétněji specifikována a odkazovalo se jen na tradiční rozsah držby (napřr. společně se statkem Třebňouševes bylo prodáváno „was in dem Dorf Milowicz von alters darzue gehorig“, se Sloupnem „das Dorff Alt Bydžiow, was davon dahero zugehöret“" atd.). K tomu možno ještě dále podotknout, že ani v př́ípadech, kdy byla vesnice v kupní smlouvě jmenována bez jakéhokoliv dalšího omezení, nemuselo to znamenat její výhradní držbu - tak plukovníkovi Janu Ludvíkovi Isolanovi byla společně se statkem Zásadka prodána ves Dneboh, jejíž část ale patřila dříve, a podle všeho i v daném okamžiku, k panství Mnichovo Hradiště. ${ }^{119}$ Stejně tak Gerhard Taxis koupil v roce 1625 panství Valečov s pěti vesnicemi, mezi nimiž figuruje i Branžež - ta však

117 Tak jako „ein Theil der Herrschaft Aiche (Eiche)“, resp. „ein Theil des Guts, so zue Herrschaft Aiche gehörig“ bylo prodáno 5 vesnic Augustinu Morandovi (4. 3. 1624), Hodkovice nad Mohelkou Kryštofovi Ecksteinovi z Erneggu (13. 4. 1624), 6 vesnic Jakubovi Reichardovi Heusterovi (6. 5. 1624), Starý Dub Caesaru Gillovi (15. 7. 1624). Také Nudvojovice byly 4. 3. 1624 prodány jako „ein Theil des Herrschaft Swigan".

118 Zatímco ovšem Stráž byla jako panství označena ve smlouvách z let 1627 i 1633, v souvislosti s Valečovem a Lemberkem bylo při prvním prodeji (v letech 1625, resp. 1627) užito termínu „Gut““ a jako „Herrschaft“ je zachytily teprve kontrakty z roku 1633. Zajímavá je v tomto ohledu zejména smlouva z roku 1627 , uzavřená s Adamem Vilémem Schellartem - zatímco Stráž pod Ralskem je „Herrschaft“, ač k ní kromě městečka patří jen 6 vesnic, Lemberk s 12 vesnicemi je označen jako „Gut“. 
částečně patřila k druhému dílu valečovského panství, který v roce 1617 připadl Albrechtovi Kapounovi ze Svojkova a zůstal v jeho držení i v pobělohorské době. ${ }^{120}$ Měnící se rozsah panství byl zřejmě důvodem, proč bylo při prodeji Lemberka v roce $1629 \mathrm{v}$ rámci následných výhrad kupujícího zdůrazněno, které dvě vsi (Žibřidice a Suchá) zůstávají i s prŕíslušenstvím ve vlastnictví Valdštejna. Toto negativní vymezení bylo ale v rámci studovaného souboru zcela výjimečné.

Vesnice byly postupovány se všemi poddanými, jak reálně usedlými, tak i zběhlými (,mit allen angesessenen und von solchen Gütern ohne ordentliche Lossbrief entwichene Unterthanen“), a se všemi požitky, které vlastnictví panství přinášelo, tedy právy („Rechten“), spravedlnostmi, jimiž byla míněna především vrchnostenská jurisdikce (,Gerechtigkeiten“), platy (,Zinsen“, někdy je tato položka poněkud rozvedena - „Geldt und anderen Erbzinsen“, 121 „Zinsen an Geldt, Hennen und Inselt“, 122 „Erbzinsen an Geldt, Hünnern, Eier, Schünken, Hasselhünner und andern von etlichen Wiesen und Äckern steigenden und fallenden Zinsen“"123 atp.), robotami („Roboten“), a případně dalšími požitky, způsob jejichž popsání a vymezení ve smlouvách dosti variuje. Výjimečně byly přímo ve smlouvě vyčísleny počty osedlých $\mathrm{v}$ jednotlivých vesnicích. ${ }^{124}$

Statky jako celek byly samožrejmě prodávány s veškerým dalším př́islušenstvím, jehož podrobný výčet by ovšem smlouvy neúnosně zatížil. Proto se v popisu prodávaného majetku objevovaly pouze ty jejich součásti, které měly zásadní hospodářský význam. Šlo v prvé řadě o mlýny („Mühlen“, př́padně „Mahlmühlen“), uváděné někdy jmenovitě, jindy nikoli, dosti často s explicitním údajem o počtu mlýnských kol (který mohl mít dále významné konsekvence berní). ${ }^{125}$ Jen zrrídka bylo zdůrazněno právo na část semletého obilí, pravidelně příslušejícího mlynářům jako tzv. měřičné („,mit den Nutzungen von Getreid und Schweinmästungen“, 126 resp. „mit dem jährlichen Kornzinß unnd Schweinmastung“127). To bylo zajištěno prostřednictvím tzv. mlýnského př́imusu, tj. poddaným autoritativně uložené povinnosti, využívat k mletí svého obilí konkrétní mlýn. Zásadní význam mlýnů podtrhuje skutečnost, že při prodeji Studence byl do výčtu příslušenství výslovně zahrnutý i pustý objekt tohoto druhu (,der wuster Mühl in den niedersten Wiesen“).

Najdou se ale i smlouvy, v nichž se mlýny obecně, bez jakéhokoliv př́slušenství, zahrnují mezi př́slušenství prodávaného léna. Totéž platí i pro pily („Brettmühlen“) a ovčíny („Schäfereien“), u nichž je ovšem přesnější specifikace spíše výjimkou než pravidlem.

120 Díl valečovského panství s centrem v Kněžmosti představoval jednu z mála enkláv uvnitř frýdlantského knížectví, kterou Valdštejn nedokázal během své vlády získat. Její rozsah viz DZV 309, fol. J 18v - K 7v (osedlí v Branžeži jsou vyjmenováni na fol. J 25r). Albrecht Kapoun byl během povstání nezletilý, a proto pobělohorským konfiskacím na rozdíl od strýce Kryštofa, majitele druhé poloviny panství, unikl.

121 Tak při prodeji Bílých Poličan Purkartovi Kordulemu ze Sloupna.

122 Tak při prodeji Hodkovic nad Mohelkou Kryštofovi Ecksteinovi z Erneggu.

123 Tak při prodeji Fořtu Magdaleně Mičanové z Hodkova.

124 Tak při prodeji Lázní Bělohrad Rosině Zilvárové z Tropčic se mluví o 15 osedlých v Nové Vsi, resp. o 8 osedlých „mit Zugviehe“ a o 21 „ohne Zugvieh“ souhrnně v Nové Vsi a Uhliŕŕch, ostatní vesnice jsou ale uvedeny jen jménem, bez počtu hospodářství.

125 Jako př́klad podrobného popisu lze uvést smlouvu o prodeji lemberského panství v roce 1633 , kde se hovoří o „dreien Mahlmühlen, eine zu Markersdorf von zweien Mühlgängen, die andere in St. Christophori Thal, auch von zweien Mühlgängen, die dritte zu Hernsdorf von einem Gang“.

126 Tak při prodeji statků Stráž pod Ralskem, Lemberk a Tulcpach Adamovi Vilémovi Schellartovi.

127 Tak při prodeji Fořtu Magdaleně Mičanové z Hodkova. 
Poměrně zřídka je explicitně uvedena olejna („Ölmühle“), ${ }^{128}$ kovárna („,Schmiedwerkstatt mit dem Schmiedzeuge“) ${ }^{129}$ či masný krám (,Fleischbank“), ${ }^{130}$ což je dozajista odrazem celkově nevelkého počtu těchto výrobních objektů. ${ }^{131}$ Při prodeji Velehrádku byly ve smlouvě výslovně zmíněny cihelna a tři lomy (,eine Ziegelhütten und drei Steinbrüche“), cihelna se také objevuje v obou smlouvách vztahujících se k panství Hrubý Rohozec. Je ovšem třeba se ptát, zda se lze na text dochovaných smluv spolehnout do té míry, že lze s jistotou prohlásit, že se jiné podniky tohoto druhu na frýdlantských lenních statcích nevyskytovaly. Spíše asi ne. Obecně totiž platí jakási nepřímá úměra v tom smyslu, že čím bylo prodávané panství menší, tím podrobnější byl v kontraktu jeho popis. U větších dominií se zpravidla vystačilo s rámcovým vymezením, což bylo umožněno tím, že byla podoba předávaného statku podrobně zachycena v urbáři či jiném soupisu obdobného charakteru.

Pouze při prodeji panství Stráž pod Ralskem (Vartenberk) a Lemberk byl výslovně do držby vazalů převeden též pivovar („Breuhaus“). To bylo způsobeno tím, že se Valdštejn celkem důsledně snažil udržet si ve Frýdlantsku pivní regál - srovnej dále uvedené výminky prodávajícího, $v$ nichž se pravidelně opakuje povinnost odběru piva z knížecích pivovarů - a ponechání vaření piva v rukou držitelů lenních statků bylo zcela ojedinělé.

Zcela jinak je zřejmě nutno interpretovat mlčení smluv, nakolik jde o krčmy a nálevny. Ty byly v raně novověké kontraktuální praxi obvykle důsledně evidovány, avšak v souboru sledovaných smluv se pouze při prodeji Stráže pod Ralskem Kryštofovi Pavlovi z Lichtenštejna-Kastelkornu v roce 1633 v rámci obecného výčtu součástí panství zmiňují „Kretschmen und Wirthäusern“ a ke statku Fořt patřil „das Schenkhaus ... daselbst“. Je prritom jisté, že množství těchto podniků bylo ve skutečnosti velmi značné, čemuž opět napovídá i stereotypně opakovaný požadavek odběru piva ze zeměpanských pivovarů. Z nějakého důvodu ale jičínská dvorská kancelář při přípravě smluv nepovažovala za nutné krčmy výslovně zdůrazňovat. Podobně lze předpokládat, že i chmelnic bylo více, než o kolika se smlouvy zmiňují. V rámci dochovaných smluv se také objevuje jediná vinopalna („Branntweinhaus“"), a to na panství (Lázně) Bělohrad.

Velmi rozšířenou a poměrně výnosnou formu raně novověkého režijního podnikání představovalo (nejen v českých zemích) rybníkářství. Jak ukázalo podrobnější studium pramenů vztahujících se k frýdlantským ,starolenním“ statkům, ${ }^{132}$ neskýtaly sice horské oblasti pro intenzivní chov ryb ani zdaleka ideální podmínky a počty a výnosy zdejších rybníků celkem pochopitelně nedosahovaly standardu jihočeských či středočeských nížin,

128 Dvě na panství Stráž pod Ralskem, po jedné na panstvích Hrubý Rohozec a Velehrádek.

129 Tento obrat se objevuje při prodeji panství Mladějov Valdštejnovu bratranci Janu Albrechtovi Slavatovi z Chlumu. Při prodeji Olešnice plukovníkovi Lamboyovi jsou zmíněny „Schmied- und Töpferzinsen“, nepochybně existenci kovárny (kováren) na tomto panství rovněž dosvědčující.

130 Výslovně je zmíněn při prodeji statků Fořt, Hrubý Rohozec, Okrouhle, Sloupno a Velehrádek.

131 Nevelký počet těchto výrobních podniků konstatuje i ANDĚL, Hospodářská situace drobných šlechtických statků na česko-lužickém pomezí v XVII. století, s. 101, pro lenní statky na frýdlantském panství, kde jsou před vypuknutím třicetileté války písemnými prameny evidovány tř̌i pily (spojené s mlýny), dvě olejny (z toho jedna nepřímo) a jedna cihelna. Na druhou stranu nebyly zřejmě tak úplně výjimečné, nebot' olejna se objevuje např. jako součást nevelkého rytiřského statku Albrechtice, který Valdštejn v roce 1628 koupil od Anny Kyjové z Gerštorfu, avšak pro nezaplacení ceny jí ho nadále ponechal v zástavě. Blíže k tomu STARÝ, Vendito ut empto ut vendito...?, s. 141-152.

132 ANDĚL, Hospodářská situace drobných šlechtických statků na česko-lužickém pomezí v XVII. století, s. 92-96; TÝŽ, Rybníkářství na statcích frýdlantské lenní šlechty v 16. a 17. století, s. 33-52. 
i tak ale představovaly rybníky významnou součást ekonomiky těchto statků. Část nově vytvořených lén se navíc nacházela $\mathrm{v}$ oblastech nabízejících přeci jen příznivější přírodní podmínky. Ve smlouvách se někdy objevuje jen počet rybníků, jindy jsou uváděna i jejich jména. Zpravidla také dochází k bližší specifikaci rybníků v návaznosti na jejich velikost („Teich“versus „Teichel“ či „Teichlein“) a zejména úlohu v rámci pokročilého rybničního hospodářství. Tak vedle hlavních, kaprových rybníků („Karpfenteich“), se objevují rybníčky třecí či plůdkové („Streichenteichel“, eventuálně „Saementeichel“) a rybníčky výtažní (,Streckteichel“), specifický charakter pak měly rybníky pstruhové („Forellenteich“). Lze předpokládat také odpovídající množství haltýřů, i když se „Fischhalter“ výslovně objevuje jen zř́ídka. ${ }^{133}$

V některých smlouvách se zdůrazňuje i vlastnické právo ke konkrétním vodním tokům, řekám či potokům. Někdy se mluví pouze o blíže nespecifikovaném „dílu“ dotyčné vodoteče (tak Olešnice byla prodána s ,ein Stück Wassers von der Elb ... wie auch drei andere Bäch und Wasserläufe"), jindy je prodávaný úsek vymezen přesněji, a to bud' konkrétními geografickými údaji (k nudvojovickému lénu měla patřit řeka Jizera „,von den Wiesen, so Perný genandt werden, bis zu dem Ende der ,Acker‘ so zum Mayerhof Nudwogowicz gehören“), nebo alespoň délkou úseku (plukovník Isolano dostal v rámci chocnějovického statku poslední úsek říčky Mohelky, ve smlouvě popsaný jako „einem Forellenbach auf eine halbe Meil weges lang, bi $\beta$ unter da $\beta$ Schlo $\beta$ Zasadka, da darselb in die Iser fallet"“).

Jen v některých př́padech je v souvislosti s řekami a potoky výslovně zmíněno právo rybolovu („Fischerei“), často spojené s konkrétní vodotočinou. Tak výše uvedený Isolano koupil v rámci zásadeckého panství právo chytat ryby ve velmi přesně vymezeném úseku řeky Jizery (,den freien Fischfang auf der Iser von dem Laukowiczer Grund an bis zu den alten Steig zu Münchengrätz“) a podobně když zemský hejtman Taxis koupil statek Valečov, bylo mu právo chytat ryby a raky (,Gerechtigkeit Fisch und Krebs darin zu fangen“) rezervováno v potoce Kněžmostka od rybníka Patřín ke kněžmostskému mlýnu. Do třetice návarovské panství zahrnovalo při prodeji v roce 1627 úsek řeky Kamenice, v níž bylo možné lovit pstruhy, lipany a jiné druhy ryb (,darinnen man Föhren, Äschen und allerlei andere Fisch zu fischen befugt"). Lze ovšem předpokládat, že toto právo frýdlantským leníkům příslušelo ve všech př́ípadech. Tak například se nepř́imo objevuje i v obecném vymezení příslušenství statků Boleslav a Poustka (,sambt beden dero Rittersitzen, Gebäuden, Obstgarten, Forbergen, Ackern, Wiesen, Hölzern, Wilden, Fischereien, Fohrenbachen, Teichen, Mühlen, angessesenen und ohne ordentlichen Lossbrief davon entwichenen Unterthanen, Gärtnern, Hausleuten, dero Diensten und Zinsen ... mit dero Hofediensten und Roboten, Gerichten, Rechten und Jagden und allen anderen Gerechtigkeiten“).

Dosti často jsou pod popis předmětu prodeje subsumovány též informace o lesních porostech. Vzhledem k tomu, že hustota osídlení byla v 17. století o poznání menší než dnes a krajina byla zalesněna z velké části, je nepochybné, že lesy tvořily takřka ve všech př́padech podstatnou část lénem postupovaných pozemků. V některých smlouvách se v obecném výčtu prŕíslušenství objevilo prosté s lesy (,mit den Walden“) či se všemi prŕíslušejícími lesy (,mit allen denen vor diesen zugehörigen Wäldern“, ${ }^{134}$ „,mit unterschiedli-

133 Při prodeji Holovous byl německý termín Fischhalter doplněn dovětkem „böhmisch Sádky genannt“.
134 Tak při prodeji Bílých Poličan Purkartovi Kordulemu ze Sloupna. 
chen Stücken Waldes, so zu diesen Gutt gehören“) ${ }^{135}$ stejně tak je třeba s nimi spojit občas se vyskytující výraz dřeva („Hölzern“). Dokládají to ostatně smlouvy o prodeji Hrubého Rohozce, v nichž se objevuje obrat „Wald und Holtz“, resp. „Wälder und Holzung“, nebo třeba smlouvy vztahující se k Návarovu (v roce 1627) a (Lázním) Bělohrad, kde je synonymita pojmů avizována spojkou nebo (,zwei Walde oder Gehöltze“, resp. „zweien Stücken Holtzung oder Waldes“). Není ovšem každopádně pochyb o tom, že byly lesní porosty převáděny i smlouvami, v nichž se o nich žádná zmínka neobjevuje.

Některé smlouvy výslovně konkrétní lesy zahrnují, což lze nejspíše interpretovat tak, že šlo bud' o hvozdy hospodářsky zvláště významné, nebo o porosty situované na hranicích převáděných statků, u nichž by př̀ jejich neuvedení mohla panovat pochybnost, zda se na ně smlouva vztahuje, či nikoliv. V tomto směru lze poukázat na prodej statku Fořt Jindřichovi ze Saint Julienu, kdy vedle čtyř konkrétních lesů či jejich dílů (,Wäldern auf drei unterschiedlichen Orten, als Hinter Zdrbno und bei der Schwarzen Lain, item hinter Welehrad in dem Dzban genandt, siebenzig Messtrick, und ein Theil eines Waldes Petrowský genannt, bei sechzig Mess-stricken“) byly „Wäldern“ uvedeny také v seznamu typů pozemků, které byly na nového vazala převáděny. Pozornost zasluhuje zejména les Džbán pod relativně vzdáleným Velehrádkem, který byl centrem jiného lenního statku zde bylo jeho explicitní zahrnutí do smlouvy z hlediska právní jistoty jistě velmi žádoucí.

Velmi kolísavá byla míra přesnosti, se kterou byly tyto konkrétní lesy ve smlouvách popsány. Někdy se vystačilo s jejich pojmenováním, či hrubým nastíněním jejich polohy (obojí při prodeji statku Roveň - „zwei Wälde, einer Zelenka genannt, der ander unter dem Meyerhof Rowen“), jindy byla poloha lesa naznačena poněkud přesněji (,einen Waldt Wlkowina genannt von den Nawarowischen Äckern an bis unter das Dorf Stanoweg“"). Nezřídka byla také uvedena přesná rozloha jmenovaného lesa, přičemž jako měrná jednotka se častěji než výše uvedené štrychy vyskytovaly leče (,Stallungen“, resp. méně často „Bestallungen“) a př́padně též ještě menší tenata („Netzen“). Celková výměra se přitom objevila i v některých smlouvách, kde bližší specifikace lesů obsažena nebyla - př́ikladem může být prodej statku Valečov se zhruba čtyřiceti lečemi lesů („die Wälder, die bei vierzig Stahlungen sein“). Občas byl les popsán prŕivlastkem - tak jsou ve smlouvách výslovně zmíněny lesy „černé“" (,schwarz") nebo bukové („Aichenwaldt").

Z dalších atypických položek je možno zmínit šmelcovací hut’ v Arnultovicích s užitkem z tamních dolů na měd' na panství Heřmanovy Sejfy (,die Schmelzhütten und Nutzung des Kupferwerks zu Arnsdorf“). Několikrát se objevují lázně (koupele) - jmenovitě opět v Bělohradě či v chalupě na podkrkonošském statku Fořt (,,ein Calup in St. Joannis, warinnen Badt"), dále se lednice a koupel u pramene zmiňuje při poplužním dvoře v Holovousích (,einer erbaueten Eisgrube und Baadstube ob dem Mayerhof an einem frischen Quellwasser“). Při prodeji panství Studenec Johaně Uršule Zárubové bylo konstatováno, že k němu Valdštejn ještě před prodejem připojil poplatný dvưr ve Studenci, který se souhlasem předchozí vrchnosti držela Barbora Kobíková z Kopidlna, ${ }^{136}$ a že finančně vypořádal i nároky, které ke statku vznášeli sourozenci a strýcové Straníkové z Kopidlna. Kromě

\footnotetext{
135 Tak při prodeji Chrastné Volfovi Ladislavovi ze Šlejnic.

136 V opisu smlouvy je př́ijmení zkomolené na „Robickin“, šlo ale nepochybně o Barboru, vdovu po některém příslušníkovi rodu Kobíků z Poříčan, o níž jsou četné zmínky v materiálech uložených v NA Praha, fond Stará manipulace (=SM), sign. S 84/8, i.č. 3202, kart. 2199.
} 
toho zde byl další dvůr ve vsi Rovnačov, který byl rovněž ve šlechtických rukou a měl v nich zůstat, dokud to vrchnost umožní. ${ }^{137}$

Další hospodářsky více či méně významné součásti panství se již ve smlouvách objevovaly toliko v podobě obecného termínu. Tak byla panství prodávána společně s polnostmi (,Äckern“, „Feldern“), přičemž někdy byly ještě zdůrazněny poddanské povinnosti s nimi spojené, dále s křovinami a porostlinami („Püschen und Streuchern“), loukami (,Wiesen“, resp. „Wieswachsen“), pastvinami („Hüttgarten“, resp. též „Grassgarten“), řidčeji se objevují též sady („Baumgarten“ a „Obstgarten“), zeleninové, resp. kuchyňské zahrady („Garten zu allerlei zu Gemüs“, „Kuchelgarten“, „Garten zu allerlei Kuchel Speis“) či chmelnice („Hopfengarten“), popř́padě další typy pozemků. Z movitého inventáře byl reflektován především dobytek (,Zug- und andern Viehe“), ovce (,Schafviehe“) či obilí („Getreide“), vždy ale rovněž jen obecnou zmínkou.

Každopádně nutno zdůraznit, že vymezení předmětu prodeje je v jednotlivých smlouvách velmi rozličné, a to jak pokud jde o strukturu a podrobnost jeho vymezení, tak ve vztahu k užívaným jazykovým obratům. Nad rámec shora uvedeného výkladu se zde objevuje celá řada dalších odchylek a svébytností. A to i ve smlouvách pečetěných v téže době. $\mathrm{Z}$ toho lze s jistotou usuzovat, že tvorba smluv neprobíhala jednotně podle standardizovaného vzoru, ale že v jičínské dvorské kanceláři mělo tuto agendu na starost několik osob s právním vzděláním či minimálně dobrým právním povědomím a každá z nich smlouvy sestavovala poněkud odlišně, podle svých nejlepších možností. Vyloučit samozřejmě nelze ani intervence kupujících, kteří mohli mít o podobě smluv svoje představy, resp. mohli připomínkovat kancelářské návrhy, avšak jen tím se odlišnosti (zejména jazykové, i pokud jde o literaci jednotlivých německých slov) rozhodně vysvětlit nedají.

V závěrečné formuli této části se každopádně doplňovalo, že jsou statky prodávány ve svých hranicích, resp. se všemi právy a spravedlnostmi tak, jak je sám Valdštejn do té doby držel a užíval. ${ }^{138}$ Spíše výjimečné jsou odkazy na podrobný popis (taxu) prodávaného statku, ${ }^{139}$ ačkoliv se zdá velmi pravděpodobné, že bylo takové sepsání (a zároveň ocenění) prováděno ne-li pravidelně, pak alespoň poměrně běžně.

137 Nacházel se v rukou Václava Vojíŕe Sasky z Vacovic, od něhož jej o půl roku později (21. ř́jna 1630) vykoupila nová držitelka Studence, Johana Uršula Zárubová z Hustířan za 160 kop míšeňských grošů. Opis smlouvy je rovněž uložen v SM, sign. S 84/8, i.č. 3202, kart. 2199.

138 Již v nejstarší smlouvě na statky Loukovec a Kostřice se objevuje obrat ,wie solche ... von ihrer fürstl. Gnaden selbst besessen, genossen und gebraucht worden“, později se ještě pravidelně objevoval doplněk „oder gebraucht hätten werden mögen“ (poprvé při prodeji Třebňouševsi). V pozdějších smlouvách se objevují též jiné, významově srovnatelné varianty - srovnej např. prodej Studence (,solch Gut auch und Grunde von ihrer fürstl. Gnaden selbst besessen, gonossen und gebraucht worden, oder gebraucht hätten werden mögen“) či Sloupna (,,in massen ihre fürstl. Gnaden solcher oben specificierten $\mathrm{F}^{`}$ Gründ bishero selbst gebraucht und genossen oder gebrauchen und niessen hätten mögen“). Z hlediska obvyklého prostorového vymezení statku se zpravidla užívalo pojmů „Gränzen“, „Revieren“ a „Reinen“.

139 Tento odkaz se objevuje při prodeji Hrubého Rohozce Františkovi Clarymu (,,alle in darüber aufgerichten Taxzettel begriffen“), Stráže pod Ralskem, Lemberka a Tulcpachu plukovníkovi Schellartovi (,,in der darüber aufgerichteten Tax beschrieben“), Bartoušova Kateřině Noue Guterdingové („obzwar die Taxa, so über das angeregte Gutt leidlicher Manen gemacht“), Lázní Bělohrad Rosině Zilvárové z Tropčic (,wie die in der gefassten Taxa nominatim beschrieben“), Studence Johaně Uršule Zárubové z Hustír̆an (,wie die hierüber beschriebene und Kaufern eingehändiste Taxa mit mehrern lautet"), a konečně i v dokumentech z roku 1633, vztahujících se k prodejům Stráže pod Ralskem Kryštofovi Pavlovi z Lichtenštejna-Kastelkornu, Lemberka Janu Rudolfovi Bredovi, Valečova Rudolfovi z Morzinu a Olešnice Vilému Lamboyovi 
V několika smlouvách se na samý konec části popisující předmět prodeje objevilo ještě explicitní zdůraznění toho, že součástí prodeje je hospodářské příslušenství statku. Tak při prodeji Hrubého Rohozce a Malé Skály Mikuláši Des Foursovi se takto objevil osev na polích, obilí, domácí zvírata a pracovní nástroje (,sambt den über Winter und Sommer besäeten Feldern, beigelassenen Getreid, Viehe und Hausgeräthe“), ve třech smlouvách o prodeji Holovous a Hradišt'ka, Miletínka a Lázní Bělohrad sestrám z Tropčic a při prodeji Lemberka Františkovi Marazzanimu je totéž v jiném pořadí a bez zbylého obilí. Stejný obrat, avšak bez osevu, se objevuje též ve smlouvě o prodeji Chrastné Volfovi Ladislavovi ze Šlejnic, o zimním osevu a hospodářském příslušenství („Beilass“) je zmínka i při prodeji Kluků Dětřichovi ze Staršedl. Obilí, dobytek a další př́íslušenství, zachycené v samostatném soupisu, zmiňuje rovněž kontrakt vztahující se ke statku Bílsko.

\subsection{Cena}

Dalši obligátní položkou kupních smluv byla pochopitelně cena, za kterou byl př́islušný, v předchozím textu vymezený lenní statek prodáván. V prvním období budování frýdlantské lenní soustavy se objevilo několik smluv, v nichž cena byla vyjádřena v míšeňských groších, které v předbělohorské době představovaly v Čechách nejobvyklejší měnovou jednotku, a okamžitě byla převedena též na rýnské zlaté. Již v téže době byly ale sepisovány i kontrakty, kde cena byla uváděna rovnou a pouze $\mathrm{v}$ rýnských zlatých, a tato praxe posléze zcela převládla. V některých případech byly ceny zaokrouhlovány, jindy se jednalo o částky nezaokrouhlené, zahrnující i drobné obnosy v menších peněžních jednotkách, jimiž byly u grošových částek denáry a u zlatkových krejcary a prŕípadně feniky. Jen ojediněle byla kupní cena vyjádřena $\mathrm{v}$ tolarech. ${ }^{140} \mathrm{~V}$ prŕípadě prodeje více statků byla uvedena finální, souhrnná kupní cena - jedinou výjimkou je prodej Bílé Třemešné a Velehrádku Jiř́ímu Sadovskému ze Sloupna, kdy byly explicitně uvedeny dílčí sumy za oba statky a následně proveden jejich (paradoxně nesprávný) součet. ${ }^{141}$

\footnotetext{
(,,in der darüber aufgerichten Taxa beschrieben“). Na taxu se odvolává také smlouva o prodeji Domaslavic manželům Cornazzaniovým, podle užité formulace šlo ale v tomto př́ípadě pouze o soupis dobytka a hospodářského vybavení (,,mit dem beigelassenen Viehe und Wirthschaftssachen laut der Verzeichnus, so der Taxa beigelegt“). Výslovně je takový soupis zachycen při prodeji Bílska (,mit dem absonderlich beschriebenen Beilass an Getraid, Vieh und wie das benannt ist"), jeho existence je naznačena i při prodeji Kluků Dětřichovi ze Staršedl (,sambt der Wintersaat und Beilass, wie der inbesonders nominatim verzeichnet ist“). Takový přehled movitostí je v úplnosti zachován např́klad v souvislosti s postoupením statku Jeřice k dočasnému uživání Alžbětě Maškové z Hodkova v roce 1628 (česky) či v souvislosti se zástavou statku Vlčice plukovníkovi Hebronovi o rok dříve. NA Praha, fond Sbírka rukopisů B, i. č. 15, sign. B 16, fol. 79r - 79v, 91v - 94r. Při prodeji Holovous a Hradišt'ka smlouva výslovně uvádí, že byl kupujícímu předán urbář („Urbari“) se soupisem poddaných a jejich povinností. Co nejúplnější nalezení podobných tax zůstává nepochybně výzvou pro další výzkum, namátkou lze upozornit, že ve VL, sign. F 67/26, kart. 40, fol. 5r - 6v je ocenění statku Bartoušov a ve VL, sign. F 67/27, kart. 42, fol. 125r - 127r, 185v - 189r a 254r - 255v se nacházejí taxy lenních statků Bílá Třemešná, Valečov a Kluky. Všechny byly velmi pravděpodobně zpracovány v souvislosti s jejich prodejem lenním držitelům. Tak byl za 11000 „Stück ganze Reichstaller“ prodán Fořt. Při prodeji části panství Český Dub Jakubovi Reichardovi Heusterovi byla cena vyjádřena alternativami 6000 ř́šských tolarů a 9000 rýnských zlatých.

141 Tak byla prodána Bílá Třemešná za 12195 zlatých 21 krejcarů a 1 a 1/2 feniku a Velehrádek za 13075 zlatých 46 krejcarů a 4 feniky, což bylo chybně sečteno na 25671 zlatých 7 krejcarů a 5 a 1/2 feniku (správný součet by byl o 400 zlatých nižší).
} 
Kupní smlouvy nejsou z velké části př́liš sdílné ohledně toho, jakým způsobem měla být dohodnutá cena uhrazena. I z toho, co se v nich objevuje, se dá nicméně rozpoznat, že se uplatňovala poměrně pestrá škála variant. První a nejjednodušší spočívala v tom, že kupující vyplatil cenu hotově ještě před převzetím statku, zřejmě zároveň s podpisem smlouvy nebo vzápětí. Tak při prodeji Třebňouševsi či Olešnice v roce 1624 se mluví o odvedení celé částky do vévodské komory, resp. účtárny (,welches Geld auch bereits vorn dato dieses Kaufbriefes in dero ihro fürstl. Gnaden Cammer bahr abgeführet worden“, „,welches Geldt auch alsbald dero ihr fürstl. Gnaden Rentcammer baar abgeführt worden“), v jiných dokumentech jsou voleny kratší obraty, v nichž absentuje vcelku nadbytečná informace, kam byly peníze předány ${ }^{142}$ - těžko v tomto směru předpokládat, že by k jičínské komoře (jejíž byla účtárna součástí) existovala nějaká alternativa. V případě nevelkého bartoušovského statku byla smlouva formálně uzavřena s Kateřinou, vdovou po Janu Nouem Guterdingovi, jednající jménem nezletilého syna Anastázia, avšak ohledně ceny se uvádělo, že ji stihl ještě za svého života hotově uhradit zemřelý Jan (,,von seinen Vatter Johann Noue Guterding Rittmeistern baar bezahlt und vergnügt worden“).

Alternativou, rovněž se vyskytující poměrně často, byl závazek kupujícího odvést smluvenou cenu až po podepsání smlouvy, a to bud' při fyzickém předání statku (tak hned v nejstarší dochované smlouvě vztahující se ke statku Loukovec se Aleš Berka z Dubé zavazoval příslušnou částku ,bei Überreichung der Gütter ihr fürst. Gn. Rentcammer abzuführen“), nebo - častěji - v době pokud možno nejbližší, ovšem přesně nespecifikované. Tuto variantu reprezentují obraty ,,alsobald baar abgeführt werden soll““, ${ }^{143}$ resp. ,alsobald baar abgeführt werden sollen“, 144 popřípadě ,,alsobald bezahlt und abgeführt werden soll“..145 Nechyběly ale ani splátkové kalendáře, v některých případech poměrně velkorysé - tak např́klad při prodeji Bílých Poličan v roce 1624 měla Engelburka Zárubová z celkových 26000 zlatých složit hotově pouhé 2000 zlatých a následně měla každý rok na svatého Havla odvést vždy 3000 zlatých, a to až do úplného vyrovnání svého závazku. Františkovi Clarimu byla v témže roce 1624 kupní cena za panství Hrubý Rohozec, blížící se k 60000 zlatým, rozdělena na osm půlročních splátek, které měl začít hradit teprve na svatého Havla roku 1628, takže k doplacení celé částky mělo dojít teprve v roce 1632. Pokud bylo hrazení kupní ceny tímto způsobem rozloženo, byli kupující pochopitelně povinni hradit zároveň se splátkami také standardní $6 \%$ úrok z nesplacené části jistiny.

Další možnost, jak vypořádat kupní cenu, představovalo převzetí Valdštejnových pohledávek kupujícími. Tímto způsobem se s vévodou zcela vyrovnal Jeroným Bukovský z Neudorfu, když kupoval dvůr Rašín se dvěma vesnicemi, takže do renthauzu nemusel

142 Namátkou lze uvést smlouvy o prodeji Boleslavi a Poustky Antonínovi Petrovi La Mottovi (,,welche Summa Geldes mehr gedachter Kaufer ... als baar erlegt und abgeführt hat“"), Rohoznice Jindřichovi ze Saint Julien, Chotče Janu Jezberovi z Kolivé Hory, dílu českodubského dominia Caesarovi Gillovi de Hungaria (,welche Summa mehr gedachter ... baar erlegt und abgeführ(e)t hat"), či Mladějova Janu Albrechtovi Slavatovi z Chlumu (,derer ihr fürstl. Gnaden von Kaufern baar vergnügt und bezahlt worden“). Sjednocená formulace se pak objevuje ve smlouvách z roku 1633 týkajících se panství Lemberk, Stráž pod Ralskem, Valečov a Olešnice (,derer Wir von Kaufer baar vergnüget und bezahlet worden“).

143 Objevují se např. př́i prodeji Horního Líšna, Bílé Třemešné s Velehrádkem, Nudvojovic, Návarova, Červených Poličan.

144 Tato dikce je obsažena ve smlouvách o prodeji Rovně či dílu českodubského panství Augustinovi Morandovi.

145 V této podobě při prodeji Bílých Poličan Purkartovi Kordulemu ze Sloupna. 
odvést ani krejcar. Popřípadě bylo možné dva posledně uvedené způsoby kombinovat když Dětřich ze Staršedl koupil v roce 1629 za 6000 zlatých Kluky, měl ve 3000 zlatých zastoupit Valdštejna v jeho dluhu u Jakuba Reicharda Heustera, dalších 1802 zlatých a 30 krejcarů představovaly jeho vlastní pohledávky vůči vévodovi. Zbývalo tedy zaplatit 1197 zlatých 30 krejcarů, které byly rozloženy do dvou splátek během roku 1630. Posledně uvedeného roku koupil dr. Adam Neff od Albrechta za 7000 zlatých dvůr a ves Bílsko a zavázal se vyrovnat vévodův dluh 4500 zlatých vůči slezskému městu Zaháň; dále měl složit 500 zlatých hotově a na zbylé 2000 vystavit v dvorské komoře jistotu (,,der kräftige untadlhaftige Assecuration“) a splatit je ve čtyřech půlročních splátkách od svatého Havla 1630 do svatého Jiř́i 1632.

Možný byl i opačný př́ipad, kdy kupující postoupili Valdštejnovi své pohledávky. Při koupi léna Studenec postoupil Václav Záruba z Hustířan, zastupující svoji dceru Johanu Uršulu Zárubovou, Valdštejnovi svoji pohledávku váznoucí na bělohradském statku a řádně evidovanou v zemských deskách. Ta činila 1878 zlatých 8 krejcarů a 5 feniků. Zbytek smluvené kupní ceny 8000 zlatých měl složit hotově, a sice tak, aby její polovina byla uhrazena hned, zbylé 4000 měl pak doplatit ve dvou termínech (3000 zlatých na svatého Havla 1630 a zbývajících 1000 zlatých při dalším termínu svatojiřském).

Zcela zvláštní případ představovala léna Holovousy a Hradišt'ko, Miletínek a Lázně Bělohrad, jež byla v červnu 1629 přenechána sestrám Miřkovským z Tropčic - Alžbětě (provdané Stošové), Kateřině (provdané Valdštejnské) a Rosině (provdané Zilvárové). I když formálně byly i zde uzavřeny kupní smlouvy, šlo fakticky spíše o směnu, nebot' dotčené šlechtičny nemusely za uvedené statky zaplatit a postoupily Valdštejnovi své dědické podíly na vrchlabském panství. Za pozornost jistě stojí, že ačkoliv měly všechny tři po svém otci Vilémovi Miřkovském stejný podíl, hodnoty jim postoupených statků se do určité míry lišily. ${ }^{146}$ Navíc ve svém součtu nedosahovaly ani zdaleka sumy, za kterou byla původně koupě Vrchlabí mezi Valdštejnem a Miřkovským smluvena. ${ }^{147}$

Ve světle skutečnosti, že velkou část držitelů frýdlantských lén tvořili Valdštejnovi důstojníci (zprvu z jeho vlastního regimentu, později po jeho postavení do čela celé císařské armády se vesměs jednalo o velitele pluků), bylo již v minulosti v literatuře uvažováno o tom, že některým z nich byla léna postoupena na srážku jejich vojenských pohledávek. ${ }^{148}$ Výslovně to potvrzuje smlouva týkající se statku Vlčice, který získal - ovšem nikoli jako léno, nýbrž do držby zástavní - Daniel Hebron. Z celkové zástavní sumy 149020 zlatých půjecil Hebron Valdštejnovi 60000 hotově, zbytek mu pak byl generalissimus podle textu smlouvy dlužen za „Kriegswerbung““. ${ }^{149} \mathrm{~V}$ jiných př́ípadech je toto řešení doložitelné z jiných pramenů. Tak když koupil plukovník Jan Ludvík Isolano v červnu 1627 za 50771 zlatých a 35 krejcarů statek Zásadka, převzal úhradu 20000 zlatých císař (formál-

146 Holovousy s Hradišt'kem byly oceněny na 23333 zlatých a 20 krejcarů, Miletínek na 19216 zlatých 57 krejcarů a 4 feniky, Lázně Bělohrad na 25316 zlatých a 40 krejcarů.

147 V roce 1624 (4. března) prodal Vilém Miřkovský panství Vrchlabí Valdštejnovi za 110000 kop míšeňských grošů, přičemž bylo dohodnuto, že ovšem zůstane v jeho držení až do úplného splacení uvedené částky. DZV 292, fol. O 13r - O 15r.

148 Tak konstatoval například KALISTA, Valdštejn, s. 109, že udělování lén důstojníkům, ,přinášelo Valdštejnovi - at' už př́mo v hotových penězích nebo převodem pohledávek, jež tito důstojníci měli z titulu své vojenské služby za císařskou pokladnou - snáze finanční prostředky nezbytné k zaplacení jeho obrovských zákupů z masy konfiskačního i soukromého majetku.“ 
ně Valdštejn na jeho žádost cenu o tuto částku snížil, přičemž Habsburk slíbil ,zase v té sumě J[eho] M[ilost] kníž[ecí] spokojiti“) a co do zbylých 30771 zlatých a 35 krejcarů se s vévodou vyrovnal tím, že mu postoupil svou pohledávku za císařskou komorou. ${ }^{150}$ O rok později koupil Isolano za 12000 zlatých blízké Chocnějovice a byl rovnou kvitován z 3284 zlatých 25 krejcarů, do nejbližších Velikonoc měl zaplatit 4000 zlatých a v roční lhůtě zbylou část 4715 zlatých 35 krejcarů. Zdá se ovšem velmi pravděpodobné, že první uvedená částka nebyla (už s ohledem na svou nezaokrouhlenost) skutečně vyplacena, ale skrývaly se za ní Valdštejnovy nedoplatky spojené s Isolanovou vojenskou službou. A podrobnější rešerše by snad mohla přinést i další doklady o takto řešených transakcích.

Konečně je zde poměrně značné množství smluv, v nichž se konstatuje, že byl prodávající ohledně kupní ceny řádně uspokojen, ale oproti výše zmíněné variantě se zde nehovoří o úhradě hotové a způsob tohoto „uspokojení“ není vůbec specifikován. Vzhledem k tomu, že se různé obraty v tomto smyslu objevují především ve smlouvách s důstojníky, ${ }^{151}$ je relativně pravděpodobné, že zde skutečně došlo k zápočtu.

Zcela bez povšimnutí zůstala otázka způsobu uhrazení kupní ceny při prodeji Stráže pod Ralskem, Lemberka a Tulcpachu plukovníkovi Schellartovi. ${ }^{152}$ A to se jednalo o částku přesahující 200000 zlatých! Patrně lze tedy i zde předpokládat, že se zaplacení od kupujícího nečekalo (jelikož byla tato transakce součástí složitějšího komplexu vzájemných pohledávek), a proto byla tato jistě velmi podstatná náležitost autorem smlouvy zcela opomenuta.

Poněkud jinak se generalissimova velkorysost projevila ve vztahu $\mathrm{k}$ bratrancům $\mathrm{z}$ rodu Valdštejnů. Literatura zdůrazňuje nekompromisnost, se kterou bohatý příbuzný odebral návarovské léno Kristiánovi z Valdštejna, jenž ho řádně nesplácel. ${ }^{153} \mathrm{Na}$ opačnou misku vah je ale možno položit jiné Albrechtovy počiny. Senior valdštejnského rozrodu, stařičký Jan Vojtěch, dostal nevelké léno Roveň k doživotnímu užívání bezplatně, podobným způsobem byl posléze $z$ vévodovy milosti existenčně zajištěn také z vězení propuštěný Jan Kryštof starší, jenž doživotně obdržel poplužní dvưr ve vsi Víska. Zejména se ale Albrecht zachoval nesmírně velkoryse vůči Janu Kryštofovi mladšímu, jemuž daroval panství Rudník (Heřmanovy Sejfy). Formálně byla uzavřena kupní smlouva, avšak ohledně placení odhadní ceny 23780 zlatých 53 krejcarů a 2 feniky se v ní konstatovalo: ,welche wie sie aus besondern fürstl. Gnaden und Mildigkeit Herrn Kaufern verehren und sambt die baar Währen bezahlt worden, gnädig hinpassieren lassen“. Alespoň co do rychlosti vyrovnání svého dluhu byl zřetelně šanován i další bratranec Hanibal, jemuž byl za 15000 zlatých

150 SM, sign. J 5/1/1, i.č. 1506, kart. 950. fol. 44r - 46r.

151 Tak např́klad při prodeji dílu českodubského panství hejtmanovi Heusterovi (,welcher Summa ihr fürstl. Gnaden allbereit contentirt sein und an Kaufern destwegen weiter nichts zu fordern haben“), Valečova podplukovníkovi Taxisovi (,,welcher Summa ihr fürstl. Gnaden von dem Kaufer auch allbereit begnügt und befriediget sein“), Hrubého Rohozce a Malé Skály plukovníkovi Des Foursovi („,welcher Summen halber höchstermelt ihre fürstl. Gnaden von Herrn Kaufern völlig vergnüget“), Valtínova, Tulcpachu a Hlemýždí pětici důstojníků (,welcher Summa halber ihr fürstl. Gnaden von dem Kaufern zu gutter Angenehmigkeit vergnügt und befriediget sein“) či Návarova vdově po plukovníkovi La Mottovi (,welcher Summa ihre fürstl. Gnaden von ernanten Lamottischen Wittib allbereit contentirt und befridiget ist, und sie also dieser Summen halber gäntzlich hiemit quittiren").

152 K této výrazné osobnosti mezi Valdštejnovými vazaly, jejíž konec byl stejně dramatický jako vzestup, blíže GAJDOŠÍK, Adam Vilém Schellart a lenní statky Albrechta z Valdštejna, s. 67-84.

153 BÍLEK, Dějiny konfiskací v Čechách po r. 1618, s. 802; JANÁČEK, Valdštejn a jeho doba, s. 288. 
prodán Miletín, přičemž režim splácení byl - soudě dle textu smlouvy - ponechán na jeho možnostech a svým způsobem i ochotě (,was aber Kaufer künftig an dieser Summa abführen wird, darüber soll ihme jedes mahl gebührliche Quittung ertheilet worden“).

Podstatná část dohodnuté ceny byla jako projev mimořádné vévodovy milosti odpuštěna ještě v dalších dvou př́padech. Konkrétně se tak stalo při prodeji Domaslavic Pavlovi Cornazzanimu a jeho choti Anně Zuzaně, rozené Salzové z Lichtenau, a při prodeji Chrastné Volfovi Ladislavovi ze Šlejnic a jeho nevěstě Ludmile Sedlecké z Drchlavy ${ }^{154}$ (obě smlouvy byly shodou okolností uzavřeny v tentýž den, 6. března 1628). Jazykové vyjádření je v každém z kontraktů poněkud odlišné, ${ }^{155}$ podstata je nicméně stejná - větší část uvedené ceny kupující platit nemuseli. Pokud jde o zbytek, za Domaslavice mělo být 6291 zlatých 48 krejcarů a 1 fenik zaplaceno hotově, zatímco Šlejnicovi a jeho nevěstě nebyl u částky 2380 zlatých 16 krejcarů a 4 feniků způsob úhrady předepsán, pouze měli uloženo Valdštejna řádně uspokojit (,,annemblicher Weise bezahlet und gutmachen sollen“). Vzhledem k tomu, že u Šlejnice je výraznější aktivita ve Valdštejnových službách doložena až ve třicátých letech a ani Pavel Cornazzani, byt' se pyšnil titulem vévodova komorníka, nepatřil k elitě frýdlantského hofštátu, zdá se pravděpodobné, že za mimořádnou úlevou, jíž se jim dostalo, je nutno hledat ženu, či přesněji řečeno ženy. Anna Zuzana Cornazzaniová z Lichtenau byla totiž hofmistryní Valdštejnovy choti, vévodkyně Isabely Kateřiny, do jejíhož fraucimoru patřila také mladá Ludmila z Drchlavy. A tak se samozřejmě nabízí hypotéza, že to byla právě přímluva vévodkyně, která vedla $\mathrm{k}$ radikálnímu zvýhodnění kupujících v těchto dvou př́padech.

Explicitně sice smlouvy vztahující se na Domaslavice a Chrastnou žádnou podobnou argumentaci neobsahují, naznačenou hypotézu ale dále nepř́mo podporuje ještě jedna skutečnost. A to ta, že pouze v obou uvedených smlouvách následuje speciální odstavec, týkající se dědičnosti udělených lén. Běžné smlouvy se k této otázce vůbec nevyjadřovaly, což lze jednoznačně interpretovat tak, že existoval všeobecně známý a přijímaný konsenzus, že lenní statky jsou dědičné, avšak toliko v prrímé legitimní mužské linii. Je to patrné i z toho, že některým leníkům poskytoval Valdštejn jako zvláštní milost mocné listy, jimiž jim (v souladu s praxí zažitou v předbělohorském českém zemském právu) povoloval svobodné odkazování těchto statků testamentární cestou. ${ }^{156}$ A když regent Jaroslav Bukovský z Neudorfu náhle zemřel a dvou těchto privilegií na statky Třebňouševes a Rašín nevyužil, byla jeho manželce a dvěma dcerám prokázána ta mimořádná milost, že jim byly uvedené

154 Druhá z uvedených smluv je poněkud nekonzistentní, nebot' jako strana kupující je v ní uveden pouze Volf Ladislav ze Šlejnic, z dalšího obsahu však vyplývá, že spolu s ním měla lenní držbu nabýt také jeho nevěsta Ludmila Sedlecká - viz výše u výkladu vztahujícímu se k vymezení smluvních stran.

155 V obou smlouvách je jako důvod srážky z kupní ceny náležitě zdůrazněna Valdštejnova milost a shovívavost a také je užito slovesa Verehren, které znamená, že srážka ceny byla provedena bez protiplnění. Odlišný je závěrečný obrat, podle nějž měla být kupní cena u manželů Cornazzaniových o částku 10000 zlatých ponížena (,von welcher Kaufsumma ihre fürstl. Gnaden den obgenannten beeden Eheleuten aus Gnaden und fürstl. Mildigkeit verehren und in Abschlag schwinden lassen zehen Tausend Gulden Reinisch“), zatímco u Volfa Ladislava ze Šlejnic a jeho snoubenky měla být tatáž částka považována za zaplacenou (,von welcher Summen ihr fürstl. Gnaden wohlbedachtig aus fürstl. Mildigkeit und Gnaden ... zehen Tausend Gulden Reinisch verehren und für bezahlt hinpassiren lassen“").

156 Soupis těchto mocných listů publikoval SVÁTEK, Dvorská kancelář Valdštejnova frýdlantského vévodství, s. 65-66. 
statky ponechány k doživotnímu užívání157 - a contrario je jasné, že bez této listiny měly statky, k nimž po Jeronýmovi nepozůstal mužský dědic, připadnout jako odumřelé léno zpátky Valdštejnovi.

Také smlouvy s manžely Cornazzaniovými a Volfem Ladislavem ze Šlejnic (a jeho snoubenkou) jednoznačně definovaly obě léna jako dědičná v mužské linii a stanovily, že mají v budoucnu přecházet podle zásady primogenitury, a to až do vymření descendentní linie (,auf seinen älteren Sohn und dieser weiter auf seinen ältern und so fortan, solang linea descendens wehrt"). Poněkud matoucí byla skutečnost, že jedním dechem s garancí držby léna až do vymření mužského potomstva bylo zdůrazněno, že na něj nemají právo kolaterální př́buzní a jsou z právního nástupnictví vyloučeni (,,von diesen Donativ excludiret sein“). Tuto doložku je totiž možno chápat bud' tak, že se udělení léna nevztahovalo na boční pokrevní př́íbuzné prvních vazalů (což ovšem bylo více než samozřjejmé), nebo tak, že léno mělo přecházet zásadně $\mathrm{z}$ otce na syna a případně odštěpené mladší rodové linie - byt' pocházející od právoplatných lenních držitelů - již k dědickému nápadu povolávány býti neměly.

Každopádně ale obě smlouvy zdůrazňovaly, že léno mají dědit pouze společní mužští potomci obou osob, jimž bylo léno postupováno - pokud by některý z manželů zemřel a druhý se znovu oženil, neměly mít děti z tohoto případného dalšího manželství žádný dědický podíl a statek měl připadnout pouze synům z manželství prvního, resp. jejich mužským potomkům. ${ }^{158} \mathrm{Na}$ první pohled by se toto ustanovení mohlo zdát mírně nejasné, nebot' z něj jasně nevyplývá, jaké dědické nároky děti z eventuálních dalších manželství měly či neměly mít v prrípadě, že by z prvního manželství žádné potomstvo nevzešlo. Pochybnosti ovšem rozptyluje následující pasáž, výslovně zdůrazňující, že pokud by uvedené manželské páry neměly bud' vůbec žádné společné děti, nebo pouze dcery, mělo léno spadnout na vévody frýdlantské jakožto lenní pány. Právě toto omezení dědičnosti na společné potomstvo je možno chápat jako doklad, že Anna Zuzana z Lichtenau a Ludmila z Drchlavy hrály zjevně významnější úlohu než jen pouhých partnerek novopečených leníků, nepochybně právě kvůli svému blízkému vztahu k vévodkyni Isabele Kateřině. A omezení dědičnosti lén je z jiného úhlu pohledu možno chápat jako kompenzaci za odpuštěnou část kupní ceny.

\subsection{Rezervace výhradních práv}

Jestliže pasáž o dědičnosti se objevuje právě jen ve dvou smlouvách, pak naopak všem kontraktům bez rozdílu je společný podrobný výčet výhradních práv, která si Valdštejn jako lenní pán pro sebe i své nástupce rezervoval. Stejně jako u některých dalších, výše

157 NA Praha, ČDK, Listiny, i.č. 176 (datováno 26. března 1630 v Jičíně). Den předtím bylo mezi dvorskou komorou a Jeronýmovými dědičkami provedeno v této souvislosti narovnání, z jehož nedodržení byly dámy v ř́ijnu 1630 komorou upomínány. VL, sign. F 67/1, kart. 1, kniha č. 2128, fol. 242v. Podobná výsada pro sestry a matku Anastazia Noue Guterdinga se objevila též ve smlouvě vztahující se ke statku Bartoušov. V obou uvedených př́ípadech se ale nejednalo o dědičnost léna v ženské linii, navíc ve smlouvě týkající se Bartoušova je toto ustanovení obsaženo na jiném místě než ve dvou následně uváděných př́íkladech.

158 Ve smlouvě vztahující se na Domaslavice je to vyjádřeno obratem „,so sollen die Kinder derselben ander Ehe mit dem Sohne erster Ehe und dessen rechtmässigen Erben an dem Gut Domoslawitz keinen Theil haben, sondern es soll dasselbe deme, der von diesem Cornazzani und Frauen Anna Susanna gebornen und seinen descendentibus mannliches Stammes allein verbleiben“, zcela totožně - jen s obměnou jmen osobních a místních - je tomu i ve smlouvě o Chrastné. 
analyzovaných segmentů smluv, i v tomto př́padě platí, že existuje relativně široká škála variant, které se v jednotlivých textech objevují.

Zpočátku, v letech 1624-1625, existovala typizovaná dikce, prrípadné odchylky od ní měly spíše marginální charakter. Později se ale začala poměrně často objevovat i ujednání obsahově i formulačně výrazně odlišná, zásadně se též začal rozcházet počet bodů, do nichž byly jednotlivé výhrady včleněny (a to ve velmi širokém rozmezí od 4 do 13). V tomto rozvolnění kancelářské praxe (protože těžko pochybovat, že právě dvorská kancelář byla místem, kde byly smlouvy koncipovány) lze ovšem stěží hledat nějaké hlubší pozadí. Stejně tak by patrně nebylo na místě vyvozovat $\mathrm{z}$ rozdílů mezi jednotlivými smlouvami apriorně, že se výhradní práva ve vztahu k jednotlivým leníkům výrazně lišila. A ani absence některých z nich v textu konkrétních smluv nemusí znamenat, že nebyla považována za samozřejmá a nebyla ze strany jičínských orgánů v př́padě potřeby náležitě vymáhána. Zde by ale bylo třeba zdlouhavého studia reálné praxe, aby bylo možno s jistotou říci, zda byly v jednotlivých případech podmínky ve smlouvách explicitně absentující beztak součástí uzavřeného kontraktu.

Stabilně jako první se ve smlouvách objevuje rezervace kolatur (podacích práv), respektive jakýchkoliv dalších práv, která se ve spojitosti s vlastnictvím jednotlivých statků mohla objevit ve vztahu k římsko-katolické církvi. Vždy byla formulována zcela obecně, a to s jedinou výjimkou - při prodeji tři statků Adamovi Vilémovi Schellartovi bylo konkrétně uvedeno, že jde o kolatury ve Stráži pod Ralskem a Dubnici a o dvě další podací práva (v tomto př́padě již lokality uvedeny nejsou, nicméně i konkrétní počet je zásadní odchylkou od stereotypně vágní formulace tohoto článku) na panství Lemberk.

V nejstarších smlouvách z let 1624-1625 se celkem stabilně objevuje na druhém místě další výhrada týkající se církevních záležitostí, a sice povinnost vazala, resp. jeho poddaných odvádět naturální kontribuci na vydržování církve (,Unterhaltung der Geistlichkeit“), totiž biskupa a farářů. K tomu je ovšem třeba doplnit, že zmínka o biskupovi je pouze odrazem Valdštejnových neúspěšných plánů na zrrízení jičínského biskupství. ${ }^{159}$ Výše dávky nebyla blíže určena, podle dikce příslušného ustanovení se ale jednalo o obilí odevzdávané ze zemědělských pozemků (tj. z lánů) a z mlýnských kol. Opakovaně se také zdůrazňovalo, že tato dávka se platí v celém vévodství, a to ze statků komorních i lenních. Totožnou povinnost zřejmě reprezentuje alternativní ustanovení, objevující se později, podle něhož měli držitelé jednotlivých statků odvádět př́íslušnou dávku - v mladších smlouvách se výslovně označuje jako „Landkorn“ či „Landgetreid“ a doplňuje se, že dříve byla nazývána též ,Thumbherren Getreid“.

Obilí se mělo vozit bud' přímo do Jičína, nebo na jiné, konkrétně stanovené místo - tak například z návarovského panství je měla Gertruda La Mottová odvádět do Semil, Mikuláš Des Fours z hruborohozeckého statku na Hrubou Skálu, Dětřich ze Staršedl, držitel drobného statku Kluky, do Bělé pod Bezdězem. Jinou variantou byla poněkud neurčitá konstatování, že obilí má být odváděno do úřadu, do komory, do renthauzu či do stodol („Schütthäusern“). Někdy se objevuje termín, ke kterému se mají tyto odvody odehrávat (k sv. Havlu či ke sv. Martinu). V př́ípadě nevelkého léna Rašín, které přikoupil regent Jeroným Bukovský z Neudorfu v roce 1625 ke svému třebňouševeskému statku, se uvádí

159 K tomu blíže zejména POKORNÝ, P. R. Jičínské biskupství. In: Rekatolizace v českých zemích. Sborník príspěvků z konference v Jičině konané 10. záři 1993. Jičín: Městský úřad, 1995, s. 73-84. 
konkrétní množství zrna, totiž 6 měřic podle míry hořické, resp. 9 měřic a 3 věrtele po přepočtení na míru malostranskou, podobně dr. Neffovi coby lennímu držiteli Bílska bylo uloženo dávat ročně 3 strychy a 2 čtvrtě pražské míry. Naopak, ve smlouvě vztahující se ke statku Studenec se objevuje poněkud neurčitá specifikace „,nach leidentlicher Erkandtnus der fürstl. Cammer“", což by se zdálo nasvědčovat, že výše této dávky mohla být v průběhu času proměnlivá.

Konečně směřuje ve prospěch církve i další ustanovení, jež bylo součástí prvotní varianty textu zeměpanských výhrad, totiž povinnost poddaných z lenních statků podílet se na stavbě plánovaného kapitulního chrámu v Jičíně („Bau des Thumbstifts zue Gitschin“), a to jednak odváděním kontribucí, jednak poskytováním fưr a také vlastní prací. V posledně uvedených prŕípadech se tak ale mělo dít za obvyklou mzdu (,doch umb gebührliche Bezahlung"), v př́íhodný čas a bez jejich př́lišného zatěžování. Také tento článek se ze smluv záhy vytrácí (naposled se objevuje ve smlouvě o prodeji statečku Rašín ze srpna 1625), což lze patrně opět dávat do nějaké souvislosti s Valdštejnovou rezignací na zřízení jičínského biskupství - stavba raně barokního chrámu svatého Jakuba ovšem byla v roce 1628 skutečně zahájena. ${ }^{160}$

Poměrně zásadní zdroj př́ijmů představovalo v raném novověku vaření piva. Valdštejn, který si byl této skutečnosti dobře vědom, zařadil pivní regál ve svém vévodství do nejužšího jádra výhradních zeměpanských oprávnění (,,vornehmstes Regale und Einkommen“) $)^{161}$ a snažil se vaření piva programově podporovat, což se projevilo na jeho stále rostoucím výstavu. Na sklonku generalissimova života, v roce 1633, byl př́ijem z vaření a prodeje piva vyčíslen na 76438 zlatých a 20 krejcarů, což byla velmi značná suma a zároveň i podstatná část celkových prŕíjmů, které z vévodství plynuly. ${ }^{162}$

Zpočátku se Valdštejn dostával do sporů s městy, která se snažila dovolávat svých starších privilegií, jež jim výrobu zlatého moku garantovala. Proti vůli všemocného generalissima měly ale tyto argumenty pramalou váhu. Nejznámější spor vedl Valdštejn s Frýdlantem a Libercem, jimž vaření piva zakázal hned po převzetí panství, v roce 1622 , tedy ještě předtím, než ze svých statků vytvořil polosamostatné knížectví. Obě města se na něj obracela s protesty i prosbami, leč marně. Valdštejn nejprve nabízel za odebrané privilegium jiné hospodářské výhody, posléze ale ztratil trpělivost a delegacím obou měst, které přišly znovu hájit stará práva, nechal rozezleně vzkázat, že objeví-li se v Jičíně ještě jednou, vrátí se domů bez hlav. ${ }^{163}$

Není tedy divu, že se výhrady vztahující se k pivnímu regálu staly integrální součástí kupních smluv, jimiž byla převáděna držba lenních statků. Pouze ve dvou smlouvách bylo výslovně uvedeno, že pivovar s př́slušenstvím si vyhrazuje vévoda, tedy že není součástí převáděného majetku. Stalo se tak při prodeji trojice statků Valtínov, Tlustec a Hlemýž-

160 Minuciózně naposledy ULIČNÝ, P. Proboštský a dvorský chrám sv. Jakuba v Jičíně. In: ULIČNÝ, P. a kol. Architektura Albrechta z Valdštejna. Italská stavebni kultura v Čechách v letech 1600-1635. I. Praha: NLN, 2017, s. 393-422.

161 ERNSTBERGER, Wallenstein als Volkswirt im Herzogtum Friedland, s. 44.

162 Tamtéž, s. 47.

163 HELBIG, J. Beiträge zur Geschichte der Stadt und des Bezirkes Friedland i. B. II. Band. Friedland i. B.: Weeber, 1894, s. 44-45; SVOBODA, M. Cui bono? Právovárečné spory v pojetí regionální historiografie 18.-20. století. Případ Frýdlantu v 17. století. In: VESELÝ, M. - KAISEROVÁ, K. (eds.). Pivo lepších časů. Sbornik přispěvků z konference konané ve dnech 20.-21. dubna 2006 ve Velkém Březnè. Ústí nad Labem: Univerzita Jana Evangelisty Purkyně. Filozofická fakulta, 2007, s. 68. 
dí pětici důstojníků v roce 1625, kdy si Valdštejn ponechal pivovar v Hlemýždí („das Breuhaus zue Schneckendorf mit deme Hopfengarten und aller Zugehör als fürbehalten ihrer fürstl. Gnaden verbleibet"), a posléze při prodeji Lemberka Františkovi Marazzanimu v roce 1629, kdy bylo príslušenství pivovaru popsáno dosti podrobně („das Breuhaus zu Lamberg mit dem Maltzhaus, vier Kellern und allen zugehörigen Gebäude mit der Breuerpfannen und dem Breuzeug, wie solch Gebreu absonderlich gelegen und beschlossen, sambt dem freien Weg zum Breuhaus, mit Holz und aller Nothdurft denselben zu jeder Zeit zu befahren, wie auch nicht weniger das Wasser aus dem zunächst gelegenen Teicht zue Maltzen und zu Breuen ungehindert zu nehmen“). ${ }^{164}$ Lze ovšem předpokládat, že na řadě lenních statků, zejména těch drobnějších, se pivovar vůbec nevyskytoval.

Výjimku ze svého regálu strpěl vévoda zpočátku pouze u svého bratrance a zároveň švagra Maxmiliána z Valdštejna, který měl v rámci Frýdlantska do značné míry mimořádné postavení. Podobně plukovník Schellart, který kromě Stráže pod Ralskem a Lemberka nabyl i několika menších statků (Valtínov, Tlustec, Hlemýždí, Domoslavice, Hodkovice nad Mohelkou), dostal ve smlouvě vztahující se ke strážskému zboží v roce 1627 zvláštní milost zajišt'ovat odbyt na nich vlastním pivem (,dass er mit seinen eigenen Gebreu dieselben versorgen und hinführo nicht verbunden sein solle, dass seine Unterthanen aus ihr fürstl. Gnaden Breuhäusern sich der Bier erholen müssen“). Teprve v roce 1633 ukázal Valdštejn v tomto ohledu větší vstřícnost - jak již bylo uvedeno, objevují se pivovary jako součást postupovaného majetku při prodeji statků Lemberk a Stráž pod Ralskem, vedle toho pak obdržel mimořádnou milost vařit si vlastní pivo také generál Jan Ludvík Isolano, držitel statků Zásadka a Chocnějovice. ${ }^{165}$

V kupních smlouvách byla v první řadě zdůrazňována povinnost poddaných prodávaného lenního statku odvádět tak jako dřive (,,von Alters“) pro potřeby pivovarů slad, obilí a dřevo k vaření a případně ke stavebním úpravám. Opět šlo o ustanovení, které se víceméně doslova opakovalo v chronologicky první vrstvě kupních smluv a později, po roce 1625 se vytratilo. Nutno ovšem jedním dechem dodat, že obsahově obdobné výminky se následně objevily i v textu mnoha dalších (byt' zdaleka ne všech) kontraktů. O množství odváděných naturálií měla podle všeho autoritativně rozhodovat dvorská komora v Jičíně. ${ }^{166}$ Těžko přitom pochybovat o tom, že stejnými povinnostmi (byt' ve smlouvě explicitně nezdůrazněnými) byli zatíženi i poddaní ostatních lenních statků. Jednotlivé varianty dochovaných smluvních ujednání přitom doplňují současné poznání

164 Ne zcela jasně je formulována jedna z výhrad v první smlouvě o prodeji panství Hrubý Rohozec v roce 1624, v níž si Valdštejn rezervoval „die Nutzbarkeiten des Breuhauses sambt den Hopfegärten und allen Schenkhäusern und Kretschmern“. I tento obrat by bylo př́ípadně možno vykládat tak, že hruborohozecký pivovar zůstal v rukou Valdštejna, tím spíše, že o kus dál byla vazalovi i jeho poddaným stanovena povinnost odebírat pivo výhradně ,,aus ihr fürstl. Gnaden Breuhaus“.

166 O odvádění „soviel die fürstl. Cammer nach leidlicher Eintheilung erkennen wird“ se hovoří například ve smlouvách o prodeji léna Rudník v roce 1628, o „leidlichem Erkandtnuss der Cammer“ v souvislosti s převodem Mladějova o rok dříve. V př́ípadě Miletínka (1629) se objevuje obrat „,nach leidenlicher des fürstl. Ambts Erkandtnus“, dotčeným úřadem se přitom nepochybně rozuměla právě dvorská kancelář. U Holovous se téhož roku píše pouze o „leidenlichem Erkandtnus“. Výjimečná je v tomto ohledu smlouva o prodeji drobného statku Bílsko Adamovi Neffovi v roce 1630, podle níž byli poddaní z této vsi povinni odvádět do (bliže nespecifikovaných) zeměpanských pivovarů „bei guter Gelegenheit“ 3 sáhy palivového dříví. 
mechanismů, jak podpora knížecího pivního regálu měla vypadat v praxi: obilí a dřevo se měly odvádět k tomu pivovaru, ze kterého bude pro dané lenní panství zlatavý mok odebírán, a to zásadně bez jakékoliv náhrady. ${ }_{167}$

I když smlouvy vazalům výslovně vařit pivo nezakazovaly, byl Valdštejnův monopol prakticky zajištěn tím, že poddaní byli povinni odebírat mok výhradně ze zeměpanských pivovarů. ${ }^{168}$ Zcela výjimečný prrípad představovaly pouze statky Zásadka a Chocnějovice, na něž měl být „tekutý chléb“ dodáván z pivovaru hraběte Maxmiliána z Valdštejna v Mnichově Hradišti. Při nedodržování zákazu šenkování cizího piva bylo v řadě smluv přestupcům vyhrožováno vysokou pokutou (,,bei hoher Strafe“) ${ }^{169}$ v několika př́ípadech konkrétně vyčíslenou na 10 tolarů, ovšem s dovětkem, že na delikventa bude uvalen ještě další trest. ${ }^{170}$ Zajímavé je, že pouze ve smlouvě o prodeji návarovského statku v roce 1627 se poukazuje na to, že se pivo veřejně pije i mimo krčmy a výčepy, a to při svatbách, svěceních kostelů a jiných př́ležitostech, a zdůrazňuje se, že i pro tyto případy platí jak povinnost odebírat pivo z vévodských pivovarů, tak eventuální pokuta 10 tolarů (a další trest). Není ovšem sporu, že totéž se vyžadovalo i na ostatních lenních a konec konců i komorních panstvích. V několika pozdějších smlouvách byla také v souvislosti s točením piva zdůrazněna povinnost točit dobrou míru, na což měly dohlížet vrchnosti - formulačně ojedinělá je opět smlouva o prodeji Návarova Gertrudě La Mottové, v níž se konstatovalo, že bude-li odhaleno, že někdo úmyslně konzumenty šidí, bude (blíže nespecifikovaným způsobem) potrestán. Není těžké domyslet si, že v pozadí stál fiskální zájem, aby poddaní odebírali pivo v co největším množství.

V několika smlouvách se objevila také zmínka o šenkování vína. V souvislosti s ním se ale pouze obecně konstatovalo, že příslušná kontribuce vybíraná císařem má být odváděna do Jičína. V některých případech bylo upřesněno, že tato kontribuce představuje 4 pinty z každého vědra a že má být odváděna co měsíc vévodskému rentmistrovi. Jak je patrné ze smlouvy s Gertrudou La Mottovou ohledně panství Návarov, mohla být tato kontribuce odváděna v naturáliích (tj. odpovídajícím množství vína), ale též v penězích při přepočtu podle obvyklé ceny.

Poněkud častěji pak byla vazalưm ve smlouvách stanovena ještě obecnější povinnost zajistit pravidelné odvádění veškerých daní a kontribucí, přináležejících císaři jakožto českému králi. Vymezení těchto dávek mělo kolísavou podobu - občas se hovořilo pouze o „monatlichen Contributiones“, 171 častěji o „,monatliche und alle andere Kaiserliche

167 Tak např́iklad ve smlouvě o prodeji hruborohozeckého panství a maloskalského panství plukovníkovi Des Foursovi v roce 1628 či Sloupna Zdeňkovi o dva roky později (,ohne Entgeld und Bezahlung“), resp. při prodeji Kluků Dětřichovi ze Staršedl v roce 1629 (zde pouze „ohne Bezahlung“).

168 V nejstarších smlouvách se v tomto ohledu zdůrazňovala úloha rychtářů, $\mathrm{s}$ jejichž výsadním postavením v rámci vesnice bylo šenkovací právo často spojeno (,Die Richter und alle Unterthanen sollen sich auch Reines andern Biers, als aus ihr fürstl. Gnaden Bräuhäusern erholen“). Při prodeji dílu českodubského panství Jakubovi Reichardovi Heusterovi se namísto rychtářů (logičtěji) uvádějí krčmáři - „die Kretschmer und Unterthanen“.

169 Textovou anomálii lze nalézt ve smlouvě o prodeji Sloupna, kde se hovoří o tvrdé a nesmiřitelné pokutě (,bei harter unnachlässiger Strafe“).

170 Smlouvy o prodeji Návarova (1627) a Rudníku (1628). K př́snému trestání narušování pivního regálu viz též ERNSTBERGER, Wallenstein als Volkswirt im Herzogtum Friedland, s. 45.

171 Tak např. při prodeji Návarova v roce 1627. 
Contribution“, ${ }^{172}$ zejména v mladších smlouvách pak byly kontribuce zmiňovány až na druhém místě za daněmi („Steuer“), přičemž někdy bylo (z hlediska smlouvy zcela nadbytečně) doplňováno, že tyto dávky - či přinejmenším některé z nich - schvalují zemské stavy. ${ }^{173} \mathrm{~V}$ drtivé většině prrípadů se ukládala povinnost odvádět tyto dávky pověřeným výběrčím („Contribution Einnehmern“), přičemž v některých prrípadech se upřesňovalo, že místem předání má být vévodská rezidence, tedy město Jičín. ${ }^{174}$ Při prodeji Návarova (1627) a Hrubého Rohozce (1628) je zdánlivě odchylné ustanovení, že peníze mají být odváděny do renthauzu v Jičíně, ve skutečnosti ale do naznačeného rámce velmi dobře zapadá, nebot' právě zde výběrčí nepochybně úrúadovali. To, že obsah př́íslušné povinnosti všech vazalů byl totožný a všeobecně známý a nepochybný, dosvědčuje velmi dobře skutečnost, že v nejmladších smlouvách z roku 1633 se tento článek objevil již jen v naprosto minimalistické podobě: „Ingleichen alle kais. Landsteuern“.175 Za nejzajímavější obsahovou odchylku tak lze považovat zcela přesný údaj, zahrnutý do smlouvy o prodeji návarovského zboží Gertrudě La Mottové - v ní jediné bylo specifikováno, že mají být císařské kontribuce odváděny z 333 osedlých. V některých případech se objevoval také závazek vrchností spolupůsobit při vymáhání dlužných peněz a obilí („Geld- und Getreidschulden“) ve prospěch jičínské komory.

V závěru knížecích výhrad ve smlouvách z roku 1624 stála dvojice článků, vztahujících se na další Valdštejnův regál, a sice lov vysoké zvěře. V prvním z nich byla avizována jeho existence a jedním dechem s ní stanovena pro poddané daného statku povinnost být k dispozici pro pomocné úkoly, pokud by zeměpán svého výhradního práva skutečně využil. Konečně pak zůstávalo na Valdštejnově vůli, aby si z těchto poddaných vybral vhodné osoby („,qualificirte Personen“) a využil je jako lesní personál („Forstknechten“), který měl být ovšem vydržován a placen z komorních prostředků. Po roce 1625 se již tyto výhrady neobjevovaly zcela pravidelně, zůstaly ale nadále dosti běžnou součástí kontraktů. V některých případech byl do nich zařazen pouze první z uvedených článků, pasáž o lesním personálu již byla vynechána. ${ }^{176}$ Občas se také objevila výhrůžka trestem, pokud by se poddaní lenního statku tímto způsobem využít nenechali, přičemž jazykové prostředky se mohly lišit. Př́ikladem mohou být smlouvy o prodeji Valtínova, Tulcpachu a Hlemýždí (,,bei gemessener Strafe“), Studence (,,bei Vermeidung harter Strafe“) či Bílska (,bei harter Peen und Straf“). Zcela lakonickou podobu pak výhrada vztahující se k lovu vysoké zvěře nabyla při prodeji několika panství plukovníkovi Schellartovi v roce 1627. Zde bylo pouze konstatováno, že má vévoda tohoto výhradního práva přiměřeně užívat („Auch die

172 Tak např. v pěti smlouvách z roku 1628 (Rudník, Bartoušov, Domaslavice, Chocnějovice, Chrastná).

173 Srovnej smlouvy u prodeji Hrubého Rohozce, rovněž v roce 1628 („Kais. Mayest. angelegte, oder von der Landschaft der Cron Böheimb bewilligte Steuer und Contributionen“), velmi podobně též při prodeji Lemberka v roce 1629. Ve smlouvě vztahující se ke statku Sloupno bylo použito formulace „Kais. Landsteuer und Contribution, wie die gewilliget, geordnet und gesetzt werden möchte“. Naproti tomu při prodeji Návarova v roce 1627 se hovořilo o kontribucích, ,,welche von der Kais. Mayestät Statthaltern zu Handen ihrer Mayest. angeordnet“.

174 Je tomu tak např. při prodeji Miletínka v roce 1629 („dem bestellten fürstl. Steuereinnember zu der fürstl. Residenz darreichen und abführen lassen“), pouze drobné odchylky lze zaznamenat u prodeje Bílska o rok později.

175 Smlouvy o prodeji Vartenberka, Lemberka, Valečova a Olešnice.

176 Např́klad při prodeji Návarova v roce 1627 či Studence a Sloupna o tři roky později. 
Wildbahn mässiglich gebrauchet werde"), přičemž v této stručné větě se nepochybně skrývalo totéž, co bylo jinde rozepsáno podstatně podrobněji.

$Z$ dalších, jen nahodile se vyskytujících výminek lze na prvním místě jmenovat výslovné zdůraznění, že na neosedlé osoby, které se na prodávaném panství pouze dočasně zdržují, at' již z jakéhokoliv důvodu (explicitně byla jako př́klad použitá hospodářská čeled'), stejně jako na jejich děti a majetek se svrchovanost lenního držitele nevztahuje. ${ }^{177}$ Při prodeji Holovous bylo navíc zdůrazněno, že přímými poddanými Valdštejna zůstanou i ti, kteří z tohoto statku pocházejí, avšak před uzavřením smlouvy se usadili na komorních statcích (,Die Hausleuthe wie die jetzt auf diesen Grunden betroffen werden, sollen der Frauen Kauferin erblich verbleiben; dagegen behalten ihr fürstl. Gnaden diejenige alle, so dieser Orte geboren und doch jetzo anderswo auf dero Cammergütern befunden werden, zu beiden Theilen umbt Weib, Kind und habender Gerechtigkeit. Das Gesind aber, so von anderswärts dahero gelassen ist und jetzo in den Mayerhöfen oder bei den Unterthanen sich befindt, soll ihr fürstl. Gnaden mit Unterthänigkeit verhafft verbleiben“").

Při prodeji Hrubého Rohozce a Malé Skály si Valdštejn vymínil, že může svobodně a beze vší překážky nechat svážet vory po řece Jizeře do Turnova. Ve smlouvě vztahující se ke statku Kluky je (pod nikoli neobvyklou pohrůžkou těžkým trestem) obsažena povinnost poddaných svážet veškeré obilí k semletí do blíže nespecifikovaného Valdštejnova mlýna, „wie bishero gewest“. V př́padě statku domaslavického se naopak objevil článek, že pokud by zeměpán nechal př́i městečku Hodkovice zř́idit pivovar, má mlynář v prostředním domaslavickém mlýně mlít pro tento pivovar slad bez nároku na jakoukoliv platbu.

Zdůraznit je třeba, že se v této části kupních smluv někdy objevují i taková ustanovení, která sem vlastně systematicky nepatří, nebot' nejde o nějaké zvláštní výhrady, ale o další precizaci předmětu prodeje. A to bud' upozorněním na nemovitý majetek, který nemá být považován za součást prodávaného panství, nebo vyjmenováním konkrétních osob, které jsou ponechány $\mathrm{v}$ poddanosti samotného Valdštejna.

První varianta se vyskytuje celkem ve třech kontraktech. Poprvé při prodeji Rudníku $\mathrm{v}$ roce 1628, a to hned ve dvou článcích. Jednak si Valdštejn ponechal svrchovanost nad poplatným dvorem a krčmou Martina Burkharta, k níž patřila také pustá pekárna a další prríslušenství, jednak si v obsáhlém článku vyhradil měděný hamr, valchu s bělidlem, jezem a potokem, další potok s jezem tekoucí do Hostinného, s čímž byla spojena i další, spíše již podružná práva. O rok později u Holovous se zmiňuje cihelna s pozemkem nad Bohničovským rybníkem v délce i šírce dvou provazců, odkud bylo možno brát jíl na výrobu cihel. Konečně lze dva články tohoto druhu najít ve smlouvě o prodeji lemberského dominia, rovněž v roce 1629: jednak ponechal Valdštejn pro potřeby lemberského pivovaru (který si rovněž vyhradil - viz výše) trri díly lesa a potok pramenící u vsi Suchá, jednak bylo zdůrazněno, že kupující nepřebírá nic, co není ve smlouvě výslovně uvedeno („was

177 Různé formulace viz např. při prodeji Hrubého Rohozce a Malé Skály plukovníkovi Des Foursovi v roce 1628 („Hausleute, einzelichte unangesessene Weibesbilder, so vor andern Gründen dahero kommen und sich nur auf eine Zeit dieser Orten, wie bei Hausgenossen zu beschehen pflegt, gehalten, sowohl ihre Kinder, nicht weniger das Dienstgesinde, so von anderwärts Gründen dahero vermiethet und übergelassen worden, excipirt umbt ihrer Habe“) či Miletínka Kateřině Valdštenské z Tropčic o rok později (,Zum dritten die Hausleute und das Dienstgesind, so auf diesen Gründen nicht geboren, sondern von anderwärts hero sich gen Haus oder zu Dienste begeben oder gelassen, sollen und soll ihr fürstl. Gnaden sambt habender Gerechtigkeit verhaft verbleiben“). 
in diesen Kaufcontract nicht ausdrücklich mit begriefen“). Demonstrativně pak byly jmenovány vsi Žibřidice a Suchá s mlýny a vším dalším příslušenstvím.

$\mathrm{V}$ případě Holovous pak lze upozornit na jedno ustanovení, které směřovalo $\mathrm{k}$ upřesnění předmětu prodeje, vztahovalo se ovšem k věcem movitým - Valdštejnovi byla rezervována k výlovu dvouletá kapří násada v Tabšovském rybníku. Při prodeji Lukavce v roce 1630 pak autoři smlouvy pamatovali i na šindele, které byly připravené v lesích na tomto statku a které měly být v budoucnu použity dle potřeby ve prospěch komorních statků.

Pokud jde o konkrétní osoby, nejobsáhlejší článek tohoto druhu lze nalézt při prodeji Návarova Gertrudě La Mottové, při němž si Valdštejn vyhradil hned 14 poddaných z 5 různých vesnic. ${ }^{178}$ Ti mu byli nadále ponecháni v poddanství i se svými manželkami, dětmi a veškerými spravedlnostmi a nadto bylo výslovně zdůrazněno, že pokud by se kdokoliv z nich rozhodl prodat své hospodářství a odejít na vévodské komorní statky, nesmí mu $\mathrm{v}$ tom být bráněno ani ze strany návarovské vrchnosti, ani ze strany kohokoliv jiného. V ostatních př́padech šlo naproti tomu o jednotlivce, a to zpravidla takové, jejichž ponechání považovala dvorská komora za účelné pro jejich odbornost. Tak při prodeji Lemberka v roce 1629 si kvůli provozu tamního pivovaru, který na Františka Marazzaniho převáděn nebyl, Valdštejn ponechal sládka Jiřího Wernera a bednáře Kryštofa Rutha. Téhož roku byla uzavřena i smlouva o Holovousích a Hradišt'ku, na jejímž základě zůstal Valdštejnovi poddán fišmistr Jan Vrtílek a také Zikmund, šafář v ostroměřském dvoře. Ostroměř sice nebyla součástí prodávaného lenního statku, Zikmund byl ale podle textu smlouvy narozen v Holovousích, takže by za normálního stavu věcí mohla Alžběta Stošová z Tropčic vůči němu svá vrchnostenská práva uplatňovat. Ve všech těchto případech se tedy fakticky zmenšoval rozsah statku, který byl na základě smlouvy vazalovi postupován. Jiné řešení představuje naproti tomu kontrakt se Zdeňkem z Valdštejna na statek Sloupno v roce 1630: Valdštejn si měl ponechat „zu dero Diensten“ rychtáře Jana Sloupeckého a Jana Fišera, kterým mělo být umožněno prodat svá hospodářství a přejít na panství Smidary, namísto nich měli být ale na Sloupno převedeni dva jiní poddaní z komorních statků.

\subsection{Závěrečná ustanovení - potvrzení vůle, koroborace}

Již v nejstarší uzavřené lenní smlouvě na Loukovec s Kostřicemi z 26. ledna 1624 se za výhradami frýdlantského zeměpána objevil (de iure poněkud nadbytečný) článek, jehož podstatou bylo opětovné zdůraznění vůle stran dodržovat smlouvu ve všech jejích bodech a článcích. ${ }^{179}$ Ještě v průběhu téhož roku byla standardní textace tohoto článku mírně upravena, ${ }^{180}$ počínaje rokem 1627 se pak nadále objevuje v poněkud redukované podo-

178 Jednalo se o obyvatele vsí Zásada (Adam Kramer, Blažej Jeník, Jiří Šourek, Bartoloměj Šourek, Pavel Turkův), Plavy (Jan Šourek, Václav Šourek a Eliáš, ,„des deutsche Both“), Zlatá Olešnice (Jan Šmíd a Jiří Štefan), Roztoky (Havel Ručníkář) a Bohdalovice (Šimon Mutka, Adam Mutka a Jiří, syn zemřelého Jiř́iho Berky).

179 V avizované smlouvě o Loukově a Kostřicích měl článek konkrétně následující podobu: „Diesen aufrichtigen Erblehenskauf haben ihr fürstl. Gnaden als Verkaufer, wie auch wohlgedachte Herr Alesch Bercka als Kaufer ihnen beiderseits wohlbedächtig gefallen lassen, solchen auch in allen Puncten, Articuln und Clausuln festiglichen einander zu halten beständiglichen versprochen und zugesagt“.

180 Poprvé při prodeji Horního Líšna Straníkovi Straníkovi z Kopidlna 7. února 1624 („Und dergestalt haben oftgedachte ihre fürstl. Gnaden als Verkaufer, wie auch mehr genannter Stranikh als Kaufer ihnen beiderseits diesen Erblehenskauf gnädig und gutwillig belieben und gefallen lassen, solchen auch in allen Puncten, Articuln und Clausuln festiglichen einander zu halten beständiglichen versprochen und zugesagt"). 
bě. ${ }^{181}$ Konkrétní formulace mohla v jednotlivých smlouvách mírně kolísat, odchylky byly ale veskrze marginální (gramatické tvary, synonymické výrazy, přidání jednoho či dvou slov). Významově ale $\mathrm{k}$ žádným posunům nedocházelo. ${ }^{182}$ Což lze v zásadě prohlásit i o třech výraznějších odchylkách, na něž lze ve studovaném souboru narazit a jež reagují na skutečnost, že nabyvatelé statku byli při jednání s Valdštejnem zastoupeni - tak Pavel Cornazzani projevil vůli dodržovat smlouvu i jménem své manželky (,,auch anstatt seinen Ehegemahlin“), v dalších dvou př́ípadech pak rodiče kupovali statky k ruce svých dětí, což našlo i v této části smlouvy svou odezvu. Zajímavá je přitom poněkud odlišná právní konstrukce, v textu použitá: Kateřina Guterdingová je označena jako kupující k ruce svého syna („Kauferin zu Handen ihres Sohnes“), naproti tomu u Václava staršího Záruby z Hustířan bylo sice rovněž zdůrazněno, že kupuje statek na místě a k ruce své dcery, jako kupující byla ale v tomto prípadě označena ona (,,anstatt und zu Handen vielgemelter Fräulin Johanna Ursula Zarubin von Hustirzan, seiner ehelichen Tochter, als Kauferin“). Není přitom pochyb, že tato druhou variantu je nutno považovat za juristicky přesnější.

Za zcela ojedinělý př́pad je možno považovat absenci tohoto ustanovení ve smlouvě o prodeji návarovského panství Gertrudě La Mottové v roce 1627. Jedná se pravděpodobně o nedopatření, ne zcela nepravděpodobná je ovšem rovněž varianta, že se tento odstavec „vytratil“" při přepisu smlouvy do pozdějšího rukopisu. Naproti tomu s jistotou lze poukázat na to, že bylo toto ustanovení vypuštěno z potvrzujících vévodských majestátů, vydaných v roce 1633 novým držitelům statků Lemberk, Stráž pod Ralskem, Valečov a Olešnice.

Další výjimečné vybočení ze standardní skladby kupních smluv představuje prodej Bartoušova Kateřině Guterdingové v roce 1628. Zde byla bezprostředně za výše uvedený projev vůle zařazena dvě ustanovení, která by svou podstatou měla ve struktuře kontraktu patřit úplně jinam. V prvním z nich svolil Valdštejn na Kateřininu prosbu, že pokud by její syn Anastasius Noue Guterding umřel bez dědiců, že ona sama a její dcery Anna, Marie a Kateřina mohou zboží doživotně držet (,so lang eines oder das ander am Leben ist“) a teprve po smrti jich všech má toto zboží spadnout na Valdštejna nebo jeho následníky. Nadto se Kateřina dočkala z Valdštejnovy strany ještě jednoho neobvyklého privilegia, totiž že po dobu svého života měla užívat mlýn o dvou kolech při bartoušovské tvrzi s jeho prŕmusem. Oplátkou ho měla ale stavebně udržovat a po její smrti měl tento majetek opět přejít na frýdlantské vévody. Těžko popřít, že logicky by tato ustanovení patřila před oboustranný projev vůle, do kontextu jiných výhrad zeměpána; pasáž týkající se mlýna pak mohla být zařazena i do části specifikující předmět prodeje.

Dalším, tentokrát již standardním a ve všech smlouvách užitým prvkem byla koroborace. Její podoba byla ustálená a v dobovém kontextu zcela obvyklá - konstatováno bylo dvojí stejnopisné vyhotovení listiny, jež byla jak Valdštejnem, tak konkrétním kupujícím

181 Poněkud zkrácená je př́slušná pasáž již při prodeji tří panství Adamovi Vilémovi Schellartovi 22. března 1627, o osm dní později při prodeji Mladějova Janovi Albrechtovi Slavatovi z Chlumu se již objevuje text, který se stal novou normou: „Und dargestalt haben oftgedachte ihre fürstl. Gnaden als Verkaufer, wie auch Kaufer Herr Slawata ihnen beiderseits diesen Erblehenskauf belieben lassen, solchen auch in allen Puncten und Clausuln einander festiglich zu halten versprochen“.

182 Za patrně nejodlišnější od výše uvedených variant lze označit formulaci při prodeji Sloupna v roce 1630: „Und dargestalt haben viel hochgedacht ihre fürstl. Gnaden Verkaufer ihnen diesen Erblehenskauf gnädig gefallen lassen, Herrn Zdenko von Waldstein Kaufer auch demseben ganz willig angenomben“. 
vlastnoručně podepsána a zpečetěna. ${ }^{183}$ Pouze při prodeji Zásadky generálovi Isolanovi v roce 1627 bylo zmíněno a akceptováno, že podpis připojí na základě předložené plné moci jeho zástupce (,aber des Herrn Kaufers Insigl mit diesem vorgedruckten Petschaft von seinen Vollmächtigten nach vorgelegter Vollmacht unterschrieben").

Kromě smluvních stran připojovali pravidelně své pečeti a podpisy také dva svědci, s poznámkou typickou pro dobové poměry, totiž že tak činí bez jakékoliv škody pro sebe či své potomky („doch ihnen und ihren Erben unschädlich“, výjimečně „ohnschädlich“). Záhy se stalo zvykem uvádět v textu explicitně, že je toto svědectví poskytováno na Valdštejnův rozkaz (,,auf ihr fürstl. Gnaden Befehl“), ${ }^{184}$ což nepřímo vyplývá i ze zastřenějšího obratu, že byli ke svědectví ze strany zeměpána připuštěni (,zum Zeugnus mit besieglen und unterschreiben lassen“"). ${ }^{185}$ Výjimečně se u prodeje drobného léna Rašín objevilo upřesnění, že vybraní svědci kontrakt pomáhali jako zprostředkovatelé připravit (,als denen diese Sach zu verrichten und zu exequiren gnädig demandirt worden“").

Výběr svědků nepřekypuje nápaditou variabilitou a omezuje se na Valdštejnovy osvědčené služebníky, angažované ve frýdlantské správě. V nejstarších smlouvách plnili tuto úlohu pravidelně Jeroným Bukovský z Neudorfu a Jan Kuneš z Lukavec. Druhý jmenovaný je ve smlouvách z ledna a února a ve dvou ze smluv uzavřených v březnu 1624 zachycen jako hejtman českodubského panství, Jeroným Bukovský je 13. dubna a 8. května označován jako „Oberregent“. V dalších listinách jejich úřední titulatura chybí, navzdory tomu, že nelze pochybovat o tom, že své posty zastávali dlouhodoběji. Oba připojili své pečeti a podpisy ke všem smlouvám z roku 1624 a dvěma prvním (červencovým) smlouvám z roku 1625. Jedinou výjimku v této monotónní řadě představuje prodej Třebňouševsi, při němž Jeroným Bukovský sám vystupoval v roli kupujícího. Vedle Jana Kuneše byl proto jako druhý svědek povolán Jan Srnovec z Varvažova, hejtman v Bělé pod Bezdězem. V září 1625 při prodeji Valtínova, Tlustce a Hlemýždího vystupuje jako první svědek před Janem Kunešem odjinud neznámý „Kryštof Raditzky“.

Bukovský a Kuneš vystupují společně ještě ve třech listinách z roku 1627 (8. a 22. března, 6. června), rozhodující úlohu převzal ale v polovině roku 1625 svobodný pán Gerhard Taxis z Hulsu, jmenovaný do funkce zemského hejtmana frýdlantského knížectví. ${ }^{186}$ Poprvé se role svědka v „Kaufbriefu“ zhostil 6. srpna, kdy se při prodeji dvora Rašín

183 Bez významového rozdílu je kolísání mezi jazykovými variantami vyjadřujícími pokyn smluvních stran ke zpečetění (,,besiegeln lassen“, „zu besiegeln befohlen“) a prostým konstatováním, že byla listina podepsána a zpečetěna (,,besiegelt“, „,besiegelt worden“, u prodeje Hodkovic nad Mohelkou Kryštofovi Ecksteinovi z Erneggu pak mnohomluvněji ,mit fürgedruckten Insigeln bekräftiget“). Zřejmě nejpregnantněji zachycují průběh ověřování kontrakty z let 1629-1630, v nichž se hovoří o vlastnoručním podpisu Valdštejna a připojení jeho pečeti ( $\mathrm{k}$ němuž docházelo $\mathrm{v}$ jičínské kanceláři) a naproti tomu o vlastnoručním podpisu a zpečetění kupujících (srovnej např́klad ve smlouvách se třemi sestrami Miřkovskými z Tropčic - „von ihrer fürstl. Gnaden mit eigenen Händen unterzeichnet, sowohl mit dero fürstl. Insiegl bekräftiget; wie nit weniger von obgemelter Frau Kauferin unterschrieben und besiegelt worden").

Poprvé již při prodeji dílu českodubského panství plukovníkovi Heusterovi v roce 1624, dále pak např. při prodeji Zásadky a Chocnějovic plukovníkovi Janu Ludvíkovi Isolanovi. Srovnej např. smlouvu o prodeji statku Miletín Hanibalovi z Valdštejna.

186 SVÁTEK, Dvorská kancelář Valdštejnova frýdlantského vévodství, s. 58. Poprvé vystupuje s titulem „Ihrer fürstl. Gn. Herzogens zue Friedlandt wohlverordneten Landes Hauptman“ 10. července, když koupil od Valdštejna lenní statek Valečov. RAV, Valdštejniána, i.č. 2741, sign. XIV-A2h; i.č. 2787, sign. XV-X. Misiva oznamující Taxisovu instalaci do funkce byla do Jičína nicméně zaslána až 25 . července. VL, sign. F 67/33, kart. 47, fol. 59r. 
tituluje nejen jako zemský hejtman, ale též jako zplnomocněný zástupce (,vollmächtiger Statthalter"). Spolu s ním se tu objevuje Jan Kuneš z Lukavec, a to již v nové roli dvorského komorního rady. ${ }^{187} \mathrm{~V}$ letech $1627-1628$ Taxis smlouvy pečetil výhradně s regentem Bukovským (celkem sedmkrát), a poté, co regenta donutily k odchodu do ústraní zdravotní problémy (zemřel 15. května 1629), ${ }^{188}$ zaujal v roce 1629 jeho místo vedle Taxise znovu Jan Kuneš (celkem v pěti př́ipadech). Ve čtyřech smlouvách z roku 1630 pak přebral úlohu druhého svědka nově jmenovaný regent Jindřich Kustoš ze Zubřího a Lipky. ${ }^{189}$ Úřední funkce těchto pečetitelů ani $\mathrm{v}$ jediném př́ípadě v listinách zmíněny nebyly.

Teprve v poslední skupině smluv, uzavřených v roce 1633 se v koroborační formuli o svědcích nemluví a počítá se pouze s pečetěmi a podpisy smluvních stran. Dikce je v obou dochovaných čistopisech s přitištěnou Valdštejnovou pečetí (avšak bez pečeti kupujícího a podpisů) poněkud odlišná, významově ale v zásadě totožná. ${ }^{190}$ Tytéž obraty se objevují i v komplementárních jednostranných konfirmačních listinách Albrechtových. Další dvě tyto listiny, dokumentující prodej Lemberka a Olešnice, jsou v této části zcela totožné s listinou strážskou.

Ačkoliv smlouvy začínají bez výjimky datační formulí, byla hned od roku 1624 na samotný jejich závěr zařazována stručná věta, v níž bylo formálně uvedeno místo uzavření smlouvy a odkázáno na datum uvedené na opačném konci textu. V nejstarší smlouvě s Alešem Berkou z Dubé se objevila dikce „Actum Prag im Jahr und Tag, wie oben geschrieben“, avšak latinské „Actum“ bylo od té doby důsledně nahrazeno německým „So geschehen“. Všechny smlouvy z let 1624-1625 s výjimkou prodeje Hrubého Rohozce Františkovi Clarymu a Rašína Jeronýmovi Bukovskému byly vydány v Praze (,zu Prag“,


Janu Ludvíkovi Isolanovi nesly jako místo uzavření Jičín („Gitschin“, resp. „,in Unser Statt Gitschin“). Hruborohozecká smlouva je pak první vlaštovkou toho, co se stalo standardem v roce 1628, totiž že místo uzavření přestalo být uváděno. Až ve dvou smlouvách z roku 1633 se znovu objevuje hlavní město Českého království, stejně jako ve čtyřech jednostranných konfirmacích z téhož roku. Celkem tedy bylo - bráno čistě podle textu uzavřeno 26 smluv v Praze, 2 v Jičíně a u 17 není místo uvedeno. Následoval odkaz na

187 Souvisí to zřejmě s široce formulovanými kompetencemi, o nichž hovoří další Valdštejnův list z 3. srpna. FÖRSTER, Wallenstein als regierender Herzog und Landesherr, s. 22. Tamtéž doklad o tom, že Jan Kuneš se stal jedním z radů nově zř́zené dvorské komory. Dosvědčuje to pískovcová náhrobní deska v hořickém kostele, jíž naposledy podrobně popsal LOCH, J. Heraldické památky v chrámu Panny Marie v Hořicích v Podkrkonoší. Heraldická ročenka, 2010, s. 11-12.

189 Misiv obsahující jeho jmenování, datovaný 28. července 1629, cituje SVÁTEK, Dvorská kancelář Valdštejnova frýdlantského vévodství, s. 62. V květnu 1630 odjel Kustoš do Meklenburska, kde záhy upadl do švédského zajetí. Jeho odjezd potvrzuje komorní kniha, uložená ve VL, sign. F 67/1, kart. 1, kniha č. 2128, fol. 152v, k jeho dalším osudům LISCH, Ueber Wallensteins Regierungsform in Meklenburg, s. 19-25, TÝŽ, Wallensteins Kirchen- und Schul- Regierung in Meklenburg, s. 40-41 (samostatný dodatek s názvem „Georg Kustosz, Wallensteinscher Hauptmann in Meklenburg“). Před vstupem do Vadštejnových služeb byl Kustoš regentem panství trčkovských.

190 Tak ve smlouvě týkající se Stráže pod Ralskem stojí „Zu Urkundt unndt mehrer Versicherung derßelb gedoppelt eines Lauts geschrieben undt wie von Ihr fürst. Gn. so auch von genanten Herren Khauffer mit eigenen Handen unterschrieben undt besiegelt worden“, zatímco smlouva o prodeji Valečova Rudolfovi Morzinovi volí dikci „Zu mehrer Versicherung so wohl hochermelte Ihr fürstl. Gn. alß Verkhauffere, wie auch Herrn Kauffer diesen Brieff (welcher gedoppelt eines Lauts geschrieben) besigelt unndt mit eignen Handen underzeichnet haben“. 
datum v úvodu, nejčastěji v podobě ,im Jahr, Monat und Tag, wie Eingangs vermeldet“", 191 poprrípadě ,gemelt“" ${ }^{192}$ jinou variantou bylo ,wie Eingangs gedachtet“, ${ }^{193}$ resp. ,gedacht“ ${ }^{194}$ Dozajista nedopatřením je při prodeji Horního Líšna přehozeno pořadí časových údajů („Monat, Jahr und Tag“) a při prodeji části českodubského panství Augustinovi Morandovi je stejně jako ve výše zmíněné nejstarší smlouvě s Alešem Berkou vynechán měsíc („So geschehen Prag im Jahr und Tag, wie Eingangs gedacht"). Zcela originální je pak textové řešení této závěrečné věty v jednom ze dvou smluvních instrumentů, dochovaných z roku 1633, kdy při prodeji Valečova Rudolfovi Morzinovi zde stojí „So geschehen in Prag Anno et Die ut supra“.

Pro úplnost dlužno dodat, že jednostranné listiny, které byly z jičínské vévodské kanceláře o těchto prodejích vydávány, začínaly Valdštejnovou intitulací a byly tudíž uzavřeny standardní datační formulí. ${ }^{195}$ Jinak byly tyto listiny (jak dosvědčují dochované dokumenty z roku 1633 vztahující se ke Stráži pod Ralskem a Valečovu) koncipovány v zásadě stejně, samozřejmě s nutnými jazykovými odchylkami, reflektujícími jejich jednostranné, autoritativní vydání.

\section{Závěrečné úvahy}

Kupní smlouvy k frýdlantským lenním statkům představují soubor písemností, jejichž význam je možno spatřovat přinejmenším ve čtyřech základních rovinách. Z pohledu nejobecnějšího přispívají dozajista k poznání raně novověké právní kultury i právního jazyka (ovšem nikoli českého, nýbrž německého). Za druhé jsou dokladem administrativní praxe dvorské kanceláře Frýdlantského vévodství, která tyto listiny připravovala. Jsou také příspěvkem k dějinám lenního práva $\mathrm{v}$ českých zemích. Konečně pak přinášejí řadu konkrétních informací k jednotlivým lenním statkům, a tedy i regionálním dějinám severovýchodních Čech, kde se Valdštejnova „terra felix“ rozkládala. Dochované kupní smlouvy se totiž vztahují $\mathrm{k}$ historii ne méně než 41 , tedy valné většiny větších i menších, panství, která se v nedlouhé době Valdštejnovy vlády nad severovýchodními Čechami dostala do rukou jeho vazalů.

To, co určitě musí při studiu souboru dochovaných kupních smluv zaujmout na první pohled a co již bylo výše v textu opakovaně zdůrazněno, je jejich poměrně značná variabilita. I když rámcově si tyto smlouvy drží víceméně jednotnou strukturu, v jednotlivých svých částech nabízejí různá a v některých případech i značně odlišná konkrétní řešení. Platí to zejména o souboru výhrad, které si Valdštejn ve smlouvách rezervoval coby vrchní lenní pán Frýdlantského vévodství. Samotný jejich počet, ale i obsah se v jednotlivých kontraktech výrazně obměňoval, přičemž ovšem nešlo o nějaký lineární vývoj v čase, ale o kolísání nepředvídatelné a do jisté míry i obtížně vysvětlitelné. Je pravda, že první soubor smluv, uzavřených v roce 1624 , byl z tohoto pohledu poměrně uniformní, i v něm se ale lze setkat s výjimkami. Dále se již konstrukce smluv (nejen) v tomto ohledu značně

\footnotetext{
191 Poprvé při prodeji Rovně Augustinovi Morandovi.

192 Tak např. při prodeji Hodkovic nad Mohelkou Kryštofovi Ecksteinovi z Erneggu.

193 Tak při prodeji Horního Líšna Straníkovi Straníkovi z Kopidlna.

194 Tak při prodeji návarovského panství Kristiánovi z Valdštejna.

195 U dvou ze tř́ listin z 20. ledna 1633 má datace podobu „So geschehen zu Prag den zweinzigisten Januarii im eintausend sechshundert drei und dreissigisten Jahr“, u třetí (valečovské) je roční údaj ve tvaru „A[nn]o sechzehenhundert drei und dreissig“.
} 
Tab. III. Abecední seznam prodaných frýdlantských lén a jejich kupců

\begin{tabular}{|c|c|c|c|c|}
\hline & Statek & Datum & Držitel & Poznámka \\
\hline 1 & Bartoušov & $1628,29.2$ & Anastázius Noue Guterding & $\begin{array}{l}\text { Nezletilý kupující } \\
\text { zastoupen matkou. }\end{array}$ \\
\hline 2 & (Lázně) Bělohrad & $1629,18.6$ & Rozina Zilvárová z Tropčic & \\
\hline 3 & $\begin{array}{l}\text { Bílá Třemešná, } \\
\text { Velehrádek }\end{array}$ & $1624,27.2$ & Jiří Sadovský ze Sloupna & \\
\hline 4 & Bílé Poličany & $\begin{array}{l}1624,12.3 . \\
1624,28.11 .\end{array}$ & $\begin{array}{l}\text { Jan Purkart Kordule } \\
\text { ze Sloupna } \\
\text { Engelburka Zárubová } \\
\text { ze Zeltingu }\end{array}$ & $\begin{array}{l}\text { Léno podstatně } \\
\text { rozšířeno. }\end{array}$ \\
\hline 5 & Bílsko & $1630,20.3$. & JUDr. Adam Neff z Achnitz & \\
\hline 6 & Boleslav, Poustka & $1624,17.6$. & Petr Antonín Lamotte & $\begin{array}{l}\text { Jde o tzv. „starofrý- } \\
\text { dlantské“ léno. Později } \\
\text { spojeno s Návarovem. }\end{array}$ \\
\hline 7 & Červené Poličany & $1624,18.3$ & Jiří Sadovský ze Sloupna & \\
\hline 8 & $\begin{array}{l}\text { Český Dub - } \\
\text { díl (6 vsí) }\end{array}$ & $1624,4.3$ & Augustin Morando & \\
\hline 9 & $\begin{array}{l}\text { Český Dub - } \\
\text { díl (Hodkovice) }\end{array}$ & $1624,13.4$ & Kryštof Eckstein z Erneggu & \\
\hline 10 & $\begin{array}{l}\text { Český Dub - } \\
\text { díl (7 vsí) }\end{array}$ & $1624,6.5$ & Jakub Reichard Heuster & \\
\hline 11 & $\begin{array}{l}\text { Český Dub - } \\
\text { díl (Starý Dub) }\end{array}$ & $1624,15.7$ & $\begin{array}{l}\text { Ceasar Gill Jonghen de } \\
\text { Hungaria }\end{array}$ & \\
\hline 12 & Domaslavice & $1628,6.3$ & $\begin{array}{l}\text { Pavel Cornazzani a jeho } \\
\text { manželka Anna Zuzana } \\
\text { z Lichtenau }\end{array}$ & \\
\hline 13 & Fořt & $1624,8.5$. & $\begin{array}{l}\text { Magdalena Mičanová } \\
\text { z Hodkova }\end{array}$ & \\
\hline 14 & $\begin{array}{l}\text { Holovousy, } \\
\text { Hradišt'ko }\end{array}$ & $1629,15.6$ & Alžbětě Stošová z Tropčic & Léno nepřevzato. \\
\hline 15 & $\begin{array}{l}\text { Horní Líšno } \\
\text { (Slavíkovec) }\end{array}$ & $1624,7.2$ & Straník Straník z Kopidlna & \\
\hline 16 & Hrubý Rohozec & $\begin{array}{l}1624,7.12 . \\
1628,20.5 .\end{array}$ & $\begin{array}{l}\text { František Clary de Riva } \\
\text { Mikuláš Des Fours }\end{array}$ & $\begin{array}{l}\text { Připojeno panství } \\
\text { Malá Skála. }\end{array}$ \\
\hline 17 & Chocnějovice & $1628,6.3$ & Jan Ludvík Isolano & Spojeno se Zásadkou. \\
\hline 18 & Choteč & $1624,4.7$ & Jan Jezbera z Kolivé Hory & \\
\hline 19 & Chrastná & $1628,6.3$ & Volf Ladislav ze Šlejnic & \\
\hline 20 & Kluky & $1629,23.4$. & Dětřich ze Staršedl & \\
\hline 21 & Lemberk & $\begin{array}{l}1627,22.3 . \\
1629,9.8 . \\
1633,20.1\end{array}$ & $\begin{array}{l}\text { Adam Vilém Schellart } \\
\text { František Marzani } \\
\text { Jan Rudolf Breda }\end{array}$ & $\begin{array}{l}\text { Společně se Stráží } \\
\text { p. R. a Tulcpachem. }\end{array}$ \\
\hline
\end{tabular}




\begin{tabular}{|c|c|c|c|c|}
\hline 22 & $\begin{array}{l}\text { Loukovec, } \\
\text { Kostřice }\end{array}$ & $1624,26.1$ & Aleš Berka z Dubé & \\
\hline 23 & Lukavec & $1630,13.5$ & $\begin{array}{l}\text { Karel Kryštof a Jan Václav } \\
\text { Stařimští z Libštejna }\end{array}$ & $\begin{array}{l}\text { Mladší bratr v době } \\
\text { koupě nezletilý. }\end{array}$ \\
\hline 24 & Miletín & $1625,4.7$ & Hanibal z Valdštejna & \\
\hline 25 & Miletínek & $1629,15.6$ & $\begin{array}{l}\text { Kateřina Valdštejnská } \\
\text { z Tropčic }\end{array}$ & $\begin{array}{l}\text { Kupující byla man- } \\
\text { želkou Hanibala } \\
\text { z Valdštejna, zboží } \\
\text { bylo drženo společně } \\
\text { se sousedním } \\
\text { Miletínem. }\end{array}$ \\
\hline 26 & Mladějov & $1627,30.3$ & $\begin{array}{l}\text { Jan Albrecht Slavata } \\
\text { z Chlumu }\end{array}$ & \\
\hline 27 & Návarov & $\begin{array}{l}1624,11.3 . \\
1627,8.3 .\end{array}$ & $\begin{array}{l}\text { Kristián z Valdštejna } \\
\text { Gertruda La Mottová } \\
\text { ze Schinelbergu }\end{array}$ & Léno rozšířeno. \\
\hline 28 & Nudvojovice & $1624,4.3$ & $\begin{array}{l}\text { Uršula Žofie Šliková } \\
\text { z Oppersdorfu }\end{array}$ & \\
\hline 29 & Olešnice & $\begin{array}{l}1624,29.1 \\
1633,22.3 .\end{array}$ & $\begin{array}{l}\text { Zdeněk z Valdštejna } \\
\text { Vilém Lamboy }\end{array}$ & \\
\hline 30 & Rašín & $1625,6.8$ & $\begin{array}{l}\text { Jeroným Bukovský } \\
\text { z Neudorfu }\end{array}$ & $\begin{array}{l}\text { Spojeno se sousední } \\
\text { Třebňouševsí. }\end{array}$ \\
\hline 31 & Rohoznice & $1624,18.6$ & Jindřich ze Saint Julienu & \\
\hline 32 & Roveň & $1624,24.2$ & Pietro de Ferrara & \\
\hline 33 & Rudník & $1628,5.1$ & Jan Kryštof z Valdštejna & \\
\hline 34 & Sloupno & $1630,8.4$ & Zdeněk z Valdštejna & \\
\hline 35 & $\begin{array}{l}\text { Stráž pod Ralskem } \\
\text { (Vartenberk) }\end{array}$ & $\begin{array}{l}1627,22.3 . \\
1633,20.1\end{array}$ & $\begin{array}{l}\text { Adam Vilém Schellart } \\
\text { Kryštof Pavel } \\
\text { z Lichtenštejna- } \\
\text { Kastelkornu }\end{array}$ & $\begin{array}{l}\text { Společně s Lember- } \\
\text { kem a Tulcpachem. }\end{array}$ \\
\hline 36 & Studenec & $1630,5.4$ & $\begin{array}{l}\text { Johana Uršula Zárubová } \\
\text { z Hustířan }\end{array}$ & $\begin{array}{l}\text { K ruce nezletilé dcery } \\
\text { koupil panství Václav } \\
\text { Záruba z Hustířan. Její } \\
\text { matka držela léno Bílé } \\
\text { Poličany. }\end{array}$ \\
\hline 37 & Třebňouševes & $1624,29.1$ & $\begin{array}{l}\text { Jeroným Bukovský } \\
\text { z Neudorfu }\end{array}$ & \\
\hline 38 & Tulcpach & $1627,22.3$ & Adam Vilém Schellart & $\begin{array}{l}\text { Společně s Lember- } \\
\text { kem a Stráží p. R. }\end{array}$ \\
\hline 39 & Valečov & $\begin{array}{l}1625,10.7 \\
1633,20.1\end{array}$ & $\begin{array}{l}\text { Gerhard Taxis z Hulsu } \\
\text { Rudolf z Morzinu }\end{array}$ & \\
\hline 40 & $\begin{array}{l}\text { Valtínov, Tlustec, } \\
\text { Hlemýždí }\end{array}$ & $1625,13.9$ & 5 důstojníků společně & $\begin{array}{l}\text { Léno zůstalo v rukou } \\
\text { rodiny Wachtendunků. }\end{array}$ \\
\hline 41 & Zásadka & $1627,6.6$ & Jan Ludvík Isolano & \\
\hline
\end{tabular}


diferencovala. Důvod lze nejpravděpodobněji spatřovat v rozvolněné kancelářské praxi, kdy každý z odpovědných úředníků sice používal jako vzor nějakou starší smlouvu, popřípadě v kanceláři kolující formulář, promítal nicméně do sestavovaného textu i svoji vlastní představu o ideální formulaci jednotlivých smluvních ustanovení. Otázkou je, do jaké míry se mohli do formulace textu zapojovat i sami budoucí vazalové.

Každopádně se ale zdá více než pravděpodobné, že bez ohledu na konkrétně zvolené jazykové vyjádření byl rozsah zeměpanských výhrad v zásadě jednotný. Pokud se v některých smlouvách objevují články navíc a v jiných naopak absentují, lze to nejspíše vysvětlit tak, že některým úředníkům připadaly ty či ony výhrady úplně samozřejmé a nepovažovali ani za nutné je do textu smluv začleňovat. To, zda se ta či ona výhrada v konkrétním dokumentu objevuje, nelze tedy a priori přeceňovat a vyvozovat z toho větší či menší svobodu leníka při nakládání s jeho držbou. Velmi přesvědčivě to lze ostatně demonstrovat na dvojicích listin z roku 1633, vztahujících se ke statku Valečov - ačkoliv jsou textově velmi podobné, právě v části věnované Valdštejnovým výhradám lze zaznamenat i některé (pravda spíše drobné) rozdíly. ${ }^{196}$

Pouze v několika případech je možno uvažovat o hlubším významu odlišností. Zde je nutno upozornit na upuštění od povinnosti leníků poskytnout své poddané na placené práce související s budováním jičínského chrámu Páně. Př́íslušné ustanovení, které bylo pevnou součástí formuláře v roce 1624, se následujícího roku ze smluv zcela a definitivně vytratilo. Kostel se přitom v roce 1628 skutečně stavět začal. Vysvětlení je možno hledat jak v prŕípadné změně Valdštejnova vztahu k církevním institucím (zde je třeba akcentovat jeho rezignaci na vytvoření vlastního jičínského biskupství), tak možná i ve zcela pragmatickém poznání, že o pracovní síly nebude tak jako tak nouze. Jiné speciální výhrady mohly být dány zvláštními podmínkami jednotlivých lén - velmi ilustrativní př́klad představuje postoupení Hrubého Rohozce a Malé Skály plukovníkovi Des Foursovi, při němž si vévoda výslovně ponechal právo používat i na tomto panství bezplatně řku Jizeru pro účely plavení dřeva.

Mimo jakoukoliv pochybnost zůstává, že z několika vévodských regálů hrálo ekonomicky primární úlohu vaření piva, o něž se Valdštejn sveřepě a podle očekávání úspěšně střetl s vlastními městy, marně se dovolávajícími starších privilegií. ${ }^{197}$ Pouze jeho nejbližší politický spolupracovník, pokrevní př́íbuzný, švagr a později i obmyšlený dědic, hrabě Maxmilián z Valdštejna, měl od samého počátku pro svůj rozsáhlý majetkový komplex výjimku, která se dokonce posléze vztahovala i na sousedící panství plukovníka Isolana, jež měla pěnivý mok rovněž odebírat z klášterského pivovaru. Zajímavé úvahy přitom dozajista nabízí skutečnost, že podobnou milost obdržel při koupi dalšího rozsáhlého majetkového komplexu plukovník Schellart. Na sklonku života, v roce 1633, pak Valdštejn ukázal podobně přívětivou tvář i při prodeji několika dalších panství, resp. posytl várečné právo shora jmenovanému Isolanovi. Snad zde hrála roli ekonomická úvaha, že tím nedojde k závažnějšímu výpadku z příjmů, které vaření piva vynášelo (přesahovaly 76000 zlatých), i tak šlo ale o dosti překvapivý a značně nesystémový krok. ${ }^{198}$

\footnotetext{
196 NA Praha, fond Sbírka rukopisů B, i.č. 15, sign. B 16, fol. 136r; VL, sign. F 67/27, kart. 42, fol. 179r.

197 V širším kontextu ve vztahu k Frýdlantu SVOBODA, Cui bono?, s. 59-80.

198 K pivovarnictví na Frýdlantsku podrobněji ERNSTBERGER, Wallenstein als Volkswirt im Herzogtum Friedland, s. 43-47.
} 
Značně kolísavá je také míra podrobnosti, se kterou jsou jednotlivé prodávané statky popisovány. Zde lze ale vysledovat poměrně jasnou zákonitost, která je ovšem do značné míry nadčasová a zdaleka se neomezuje jen na prostor frýdlantské „št’astné země“. Jde vlastně o jakousi neprrímou úměru, vyjádřitelnou tezí: čím menší statek, tím podrobnější popis. Je to poměrně logické, nebot' vzhledem k ceně prodávaného statku se mohly jednotlivé majetkové hodnoty od jisté hranice jevit jako marginální. Tato hranice ale byla pochopitelně mnohem níže u drobných statků, sestávajících kupř́ikladu z jediné vsi, než u rozsáhlých majetkových komplexů.

Ačkoliv je výslovný odkaz v textu dochovaných smluv spíše výjimečný, lze se domnívat, že celkem pravidelným zvykem zřejmě bylo pořizovat při prodeji statku novému majiteli jeho „taxu“, tedy podrobný popis převáděného nemovitého a do jisté míry i movitého majetku. Dohledání těchto tax a jejich hlubší zhodnocení zůstává nepochybně jedním z perspektivních směrů dalšího výzkumu frýdlantských lenních statků, přičemž očekávat lze od něj data využitelná jak z pohledu historicko-ekonomického, tak i demografického. ${ }^{199}$

Literatura často uvažuje o tom, do jaké míry Valdštejn skutečně prodejem statků doplňoval hotovost do své pokladny, permanentně a enormně zatěžované válečnými výdaji, jež mu císařský dvůr ve Vídni proplácel liknavě či vůbec, a do jaké míry využíval této cesty k uspokojení pohledávek, jež vůči němu měly další osoby. Studium dochovaných kontraktů bohužel jasnou odpověd' nenabízí. V některých smlouvách se sice institut vzájemného započtení skutečně objevuje, celkově je ale jeho doložené uplatnění spíše zanedbatelné. $\mathrm{Na}$ druhou stranu, podstatná část smluv hovoří obecně toliko o uspokojení Valdštejnových nároků, což pramálo vypovídá o tom, jakým způsobem byla tato podstatná náležitost smlouvy řešena prakticky. Z hlediska čistě účetního není samozřejmě valného rozdílu mezi inkasem hotovosti či smazáním dluhu, z hlediska reálné ekonomiky jde ale o dva zcela odlišné př́ípady.

Každopádně je třeba zdůraznit, že smlouvy připravované v dvorské kanceláři Frýdlantského knížectví, resp. později vévodství vypovídají o poměrně vyspělé právní kultuře, která na půdě tohoto orgánu panovala. Nepochybně i díky tomu, že Valdštejn doceňoval význam práva pro fungování administrativy a s oblibou do vysokých úředních funkcí juristy angažoval. Již od první poloviny dvacátých let 17 . století využíval služeb jednoho z předních českých právníků, někdejšího prokurátora Jana Jezbery z Kolivé Hory, který se navzdory prokazatelným aktivitám ve službách vzbouřených stavů dokázal vyvinit i u konfiskační komise (a později obdobně odvrátil hrozící trest i v procesu po zavraždění Valdštejnově). ${ }^{200}$ Od roku 1624 patřil mezi frýdlantské leníky, když mu byl za 22000 kop míšeňských grošů prodán statek Choteč. ${ }^{201}$ Významně se zapojil též do př́pravy nedokončeného, resp. neschváleného zemského zřízení, které nechal Valdštejn pro svoji „št’astnou zemi“ připravovat. 202

199 K posledně uvedenému srovnej studii STARÝ, Soupis obyvatel vsi Bukovina u Čisté v materiálech frýdlantské dvorské komory, s. 50-63.

200 BÍLEK, Dějiny konfiskaci v Čechách po r. 1618, s. 220-221.

201 RAV, Valdštejniána, i.č. 2732, sign. XIV-Qh; NA Praha, fond Sbírka rukopisů B, i.č. 15, sign. B 16, fol. $34 \mathrm{r}-35 \mathrm{v}$.

202 STARÝ, M. Ius privatum v návrhu zemského zřízení Frýdlantského vévodství. In: BĚLOVSKÝ, P. STLOUKALOVÁ, K. Caro amico. 60 kapitol pro Michala Skřejpka aneb Řimské právo např́ic staletími. Praha: Auditorium, 2017, s. 401-403. 
Dalším významným absolventem právnických studií, který se ve Valdštejnových službách široce uplatnil, byl Štěpán Ilgen z Ilgenau, rodák z Lipska, jemuž frýdlantský vévoda svěřil funkci kanclére, tedy představitele hlavního administrativního orgánu ve svém knížectví. I mezi kancelářskými rady se to právníky hemžilo - v roce 1631 se titulem doktora práv mohli pyšnit čtyři z pěti nositelů tohoto titulu (dr. Adam Neff, dr. Jan Dill, dr. Filip Günther, dr. Jindřich Niemann), ${ }^{203}$ a i když později byli do dvorské kanceláře přibíráni spíše šlechtici, ${ }^{204}$ právní zázemí tu zůstávalo silné. Bylo to nepochybně třeba, nebot’ dvorská kancelář kompetenčně fungovala nejen jako zemská vláda (byt' v tomto ohledu zůstávala do jisté míry ve stínu zemského hejtmana a později též Valdštejnova zplnomocněného zástupce, hraběte Maxmiliána z Valdštejna), ale též jako zemský soud. Opomenout nelze v této souvislosti ani dva listy adresované vévodou Albrechtem zemskému hejtmanovi Taxisovi: v prvním z nich z roku 1625 požadoval vyhledání několika právníků, kteři by mohli být do kanceláře přijati, a podobně se měl hejtman po jednom či dvou juristech poohlédnout i v roce $1628 .^{205}$

Tak, jako se tato studie zabývala výhradně kupními smlouvami, jimiž Valdštejn prodával lenní statky ve svém vévodství, bylo by do budoucna vhodné studovat analyticky i další typy dokumentů, které byly s výstavbou a fungováním Frýdlantska spojeny. Detailní pozornost by si zasloužily císařské majestáty, jimiž se Frýdlantsku postupně dostávalo zcela svébytného právního statusu. S prodeji frýdlantských lén úzce souvisejí klasické lenní listy a lenní přísahy. Vedle prodejů přenechával Valdštejn některá léna i jako dar, o čemž byly vystavovány darovací listy („Donationsbriefy“). A samozřejmě, značný výzkumný potenciál je spojen i s kupními smlouvami „opačného gardu“, tedy těmi, jimiž Valdštejn zprvu od fisku a následně i od různých šlechticů skupoval statky a zceloval území své „terry felix“. Důkladné prostudování těchto, ale i dalších písemností (napřr. úředních knih či dochovaného materiálu aktového) může pak položit dostatečný fundament pro dosažení ambiciózní, ovšem svým způsobem přirozené mety - komplexního zpracování (nejen) právních dějin Frýdlantského vévodství, jehož poznání zůstává česká historiografie i po vydání této studie mnohé dlužna.

203 VL, sign. F 67/33, kart. 47, fol. 80r. Že byli členy zemské vlády „většinou právníci“, postřehl např. již FRANCEK, Navzdory závisti, s. 60.

204 Výjimku představoval dr. Jan Kaltschmied z Eisenbergu, přijatý za kancelářského radu v lednu 1634.

205 FÖRSTER, Wallenstein als regierender Herzog und Landesherr, s. 22; TÝŽ, Wallenstein, Herzog zu Mecklenburg, Friedland und Sagan, als Feldherr und Landesfürst in seinem öffentlichen und Privat- Leben, s. 342. 